STRUCTURAL

CHEMISTRY

ISSN 2053-2296

Received 15 August 2020

Accepted 18 September 2020

Edited by D. S. Yufit, University of Durham, United Kingdom

Keywords: dyes; salt forms; sulfonates; monoazo; coordination polymers; crystal structure.

CCDC references: 2032738; 2032737; 2032736; 2032735; 2032734

Supporting information: this article has supporting information at journals.iucr.org/c

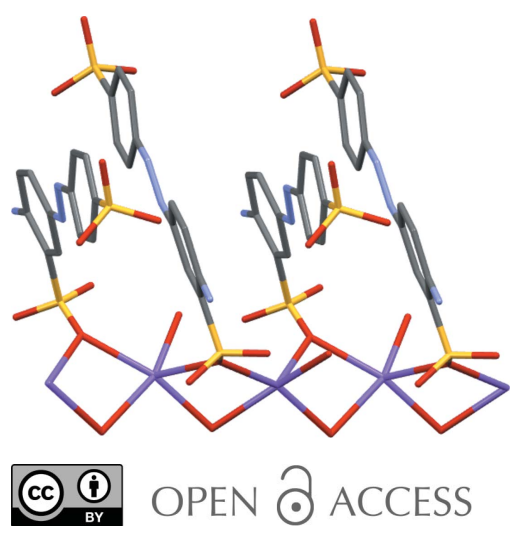

\section{Structures of five salt forms of disulfonated monoazo dyes}

\author{
Heather C. Gardner, a Alan R. Kennedy, ${ }^{a *}$ Karen M. McCarney, ${ }^{a}$ Edward Staunton, ${ }^{a}$ \\ Heather Stewart ${ }^{\mathrm{a}}$ and Simon J. Teat ${ }^{\mathrm{b}}$
}

\begin{abstract}
${ }^{a}$ Westchem, Department of Pure \& Applied Chemistry, University of Strathclyde, 295 Cathedral Street, Glasgow G1 1XL, Scotland, and ${ }^{\mathbf{b}}$ Advanced Light Source, Lawrence Berkeley National Laboratory, 1 Cyclotron Road, Berkeley, CA 94720, USA. *Correspondence e-mail: a.r.kennedy@strath.ac.uk
\end{abstract}

The structures of five $s$-block metal salt forms of three disulfonated monoazo dyes are presented. These are poly[di- $\mu$-aqua-diaqua $\left[\mu_{4}-3,3^{\prime}\right.$-(diazane-1,2-diyl)bis(benzenesulfonato)]disodium(I)], $\left[\mathrm{Na}_{2}\left(\mathrm{C}_{12} \mathrm{H}_{8} \mathrm{~N}_{2} \mathrm{O}_{6} \mathrm{~S}_{2}\right)\left(\mathrm{H}_{2} \mathrm{O}\right)_{4}\right]_{n}$, (I), catenapoly[[tetraaquacalcium(II)]- $\mu$-3,3'-(diazane-1,2-diyl)bis(benzenesulfonato)], $\left[\mathrm{Ca}\left(\mathrm{C}_{12} \mathrm{H}_{8} \mathrm{~N}_{2} \mathrm{O}_{6} \mathrm{~S}_{2}\right)\left(\mathrm{H}_{2} \mathrm{O}\right)_{4}\right]_{n}$, (II), catena-poly[[[diaquacalcium(II)]- $\mu$-2-(4-amino3-sulfonatophenyl)-1-(4-sulfonatophenyl)diazenium $]$ dihydrate], $\left\{\left[\mathrm{Na}\left(\mathrm{C}_{12} \mathrm{H}_{10^{-}}\right.\right.\right.$ $\left.\left.\left.\mathrm{N}_{3} \mathrm{O}_{6} \mathrm{~S}_{2}\right)\left(\mathrm{H}_{2} \mathrm{O}\right)_{2}\right] \cdot 2 \mathrm{H}_{2} \mathrm{O}\right\}_{n}$, (III), hexaaquamagnesium bis[2-(4-amino-3-sulfonatophenyl)-1-(4-sulfonatophenyl)diazenium] octahydrate, $\left[\mathrm{Mg}\left(\mathrm{H}_{2} \mathrm{O}\right)_{6}\right]\left(\mathrm{C}_{12} \mathrm{H}_{10} \mathrm{~N}_{3}\right.$ $\left.\mathrm{O}_{6} \mathrm{~S}_{2}\right)_{2} \cdot 8 \mathrm{H}_{2} \mathrm{O}$, (IV), and poly[ $\left[\left\{\mu_{2}-4\right.\right.$-[2-(4-amino-2-methyl-5-methoxyphenyl)diazen-1-yl]benzene-1,3-disulfonato\}di- $\mu$-aqua-diaquabarium(II)] dihydrate], $\left\{\left[\mathrm{Ba}\left(\mathrm{C}_{14} \mathrm{H}_{13} \mathrm{~N}_{3} \mathrm{O}_{7} \mathrm{~S}_{2}\right)\left(\mathrm{H}_{2} \mathrm{O}\right)_{4}\right] \cdot 2 \mathrm{H}_{2} \mathrm{O}\right\}_{n},(\mathrm{~V})$. Compound (III) is that obtained on crystallizing the commercial dyestuff Acid Yellow 9 [74543-21-8]. The $\mathrm{Mg}$ species is a solvent-separated ion-pair structure and the others are all coordination polymers with bonds from the metal atoms to sulfonate groups. Compound (I) is a three-dimensional coordination polymer, (V) is a twodimensional coordination polymer and both (II) and (III) are one-dimensional coordination polymers. The coordination behaviour of the azo ligands and the water ligands, the dimensionality of the coordination polymers and the overall packing motifs of these five structures are contrasted to those of monosulfonate monoazo congers. It is found that (I) and (II) adopt similar structural types to those of monosulfonate species but that the other three structures do not.

\section{Introduction}

Azo compounds have a long history of use as both dyes and pigments. One of the commonest subclasses is that of sulfonated azo species, where the sulfonate group is typically added to aid water solubility and/or to decrease toxicity (Hunger et al., 2003). Despite being widely referred to as organic colourants, the commercial products of sulfonated azo species are commonly metal complexes and often $s$-block metal salt forms (Christie \& Mackay, 2008). Even before large-scale crystallographic studies were available, it was recognized that small structural changes systematically changed the colour and material properties of such dyestuffs (Greenwood et al., 1986). These structure-property relationships led to an interest in more detailed structural investigations. A reasonable number of crystal structures of the salt forms of monosulfonated azo dyes and even pigments are now known (e.g. Kennedy et al., 2000, 2004, 2009; Tapmeyer et al., 2020; Aiken et al., 2013). However, far fewer relevant structures of disulfonated azo species are known, despite these being commercially commonplace. The only azobenzene-based disulfonate structures that we are aware of are those of azobenzene-4,4'-disulfonate (Soegiarto \& Ward, 2009; Soegiarto et al., 2010, 
2011). In these structures, the disulfonate ions are utilized as framework hosts for a series of functional organic guests and thus they are not of particular relevance to commercial colourant materials. Some $s$-block metal salt structures of more complicated disulfonated dyes, with naphthalene- rather than azobenzene-based azo fragments, are also known (e.g. Black et al., 2019; Kennedy et al., 2006; Ojala et al., 1994). The azo moiety in all these examples exists in the hydrazone tautomeric form and in all cases both sulfonate groups lie on only one ring system at one end of the azo bond. The only colourant relevant disulfonate structures with sulfonate groups on both the ring systems, at either end of an azo bond, are the Ca lake structures of Pigment Yellow 183 and Pigment Yellow 191 determined by Schmidt and co-workers (Ivashevskaya et al., 2009; Schmidt et al., 2009). These are relatively complex materials with pyrazolone groups between the two sulfonated aryl rings. Herein we present five new structures of $s$-block metal salt forms of azobenzene disulfonate derivatives (Scheme 1), namely, $\left[\mathrm{Na}_{2} L 1\left(\mathrm{OH}_{2}\right)_{4}\right]_{n}$, (I), and $\left[\mathrm{Ca} L 1\left(\mathrm{OH}_{2}\right)_{4}\right]_{n}$, (II), where $L 1$ is azobenzene-3,3'disulfonate; $\left\{\left[\mathrm{NaL} 2\left(\mathrm{OH}_{2}\right)_{2}\right] \cdot 2 \mathrm{H}_{2} \mathrm{O}\right\}_{n}$, (III), and $\left[\mathrm{Mg}\left(\mathrm{OH}_{2}\right)_{6}\right]-$ $[L 2]_{2} \cdot 8 \mathrm{H}_{2} \mathrm{O}$, (IV), where $L 2$ is 4 -aminodiazeniumylbenzene$3,4^{\prime}$-disulfonate; and $\left\{\left[\mathrm{Ba} L 3\left(\mathrm{OH}_{2}\right)_{4}\right] \cdot 2 \mathrm{H}_{2} \mathrm{O}\right\}_{n}(\mathrm{~V})$, where $L 3$ is 4-amino-2-methyl-5-methoxyazobenzene-2', $4^{\prime}$-disulfonate. Structure (III) is notable as it was obtained from recrystallizing the commercial dyestuff Acid Yellow 9 [74543-21-8].
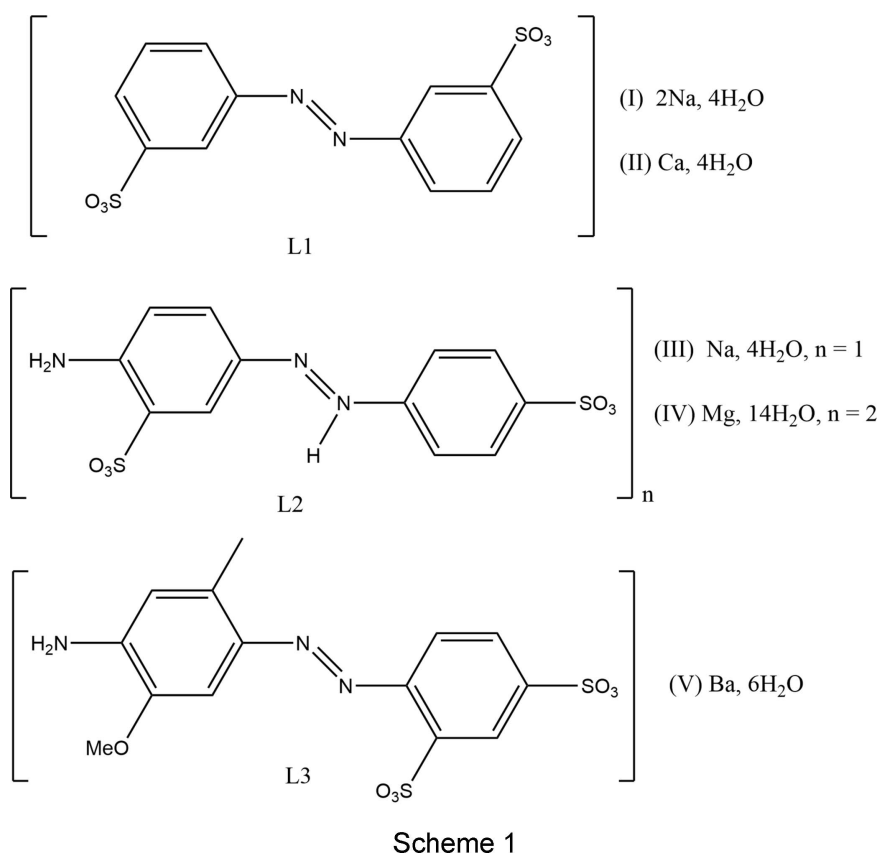

\section{Experimental}

\subsection{Synthesis and crystallization}

The Raman spectra of solid samples were measured using a Reinshaw Ramascope 2000 instrument with excitation at $785 \mathrm{~nm}$. IR samples were prepared as $\mathrm{KBr}$ discs and spectra were measured using a Nicolet Avatar 360 FT-IR.
The Na salt of azobenzene-3,3'-disulfonate, (I), was produced by the alkaline reduction of 3-nitrobenzenesulfonic acid by glucose (Galbraith et al., 1951). Yellow crystals suitable for analysis were obtained directly from the aqueous reaction mixture. IR (KBr): 1645 (br), 1470, 1419, 1235, 1199, 1107, 1081, 1045, 999, 902, 810, 712, 685, 620, 569, $528 \mathrm{~cm}^{-1}$. Raman: 1477, 1413, 1183, 1163, 1104, 995, $283 \mathrm{~cm}^{-1}$. Microanalysis found (expected) (\%): C 31.57 (31.44), H 3.56 (3.53), N 5.90 (6.11), S 13.66 (13.99).

The Ca salt (II) was prepared by adding excess $\mathrm{CaCl}_{2}$ to an aqueous solution of (I). After filtration, the resulting solution deposited yellow-orange crystals of (II) after slow evaporation (four weeks). IR (KBr): 1629, 1465, 1204, 1102, 1076, 1050, 999, 794, 712, 682, $615 \mathrm{~cm}^{-1}$. Raman: 1592, 1420, 1376, $1325,1198,1162,1124,978,822,602,381,350,277 \mathrm{~cm}^{-1}$. The crystals were somewhat hygroscopic and an acceptable microanalysis was not obtained.

The monosodium salt of Acid Yellow 9 was purchased from Sigma-Aldrich and recrystallized from water to give fibrous red crystals of (III). The Mg salt (IV) was prepared by adding an equimolar amount of $\mathrm{MgCl}_{2}$ to an aqueous solution of the monosodium salt of Acid Yellow 9. After filtering off the initial dark precipitate, allowing the remaining solution to evaporate to dryness gave red crystals of (IV). IR (KBr): 1625 , $1574,1528,1392,1162,1008,879 \mathrm{~cm}^{-1}$.

The free acid equivalent of $(\mathrm{V})$ was provided by Dystar UK. Treatment of an aqueous solution with $\mathrm{Ba}(\mathrm{OH})_{2}$ gave an orange solution. After several attempts, a simple slow evaporation (approximately four weeks) from water gave a few suitable orange crystals of (V).

\subsection{Refinement}

Crystal data, data collection and structure refinement details are summarized in Table 1. Data for (III) were measured at the Daresbury SRS Station 9.8 (Cernik et al., 1997) and for (V), data were measured by the UK National Crystallography Service (Cole \& Gale, 2012).

Disorder models were used for one non-metal-bound water molecule of both (III) and (IV), and also for one $\mathrm{SO}_{3}$ group of (IV). In all cases, a two-site model was used and site-occupancy factors were refined. Suitable restraints and constraints were applied to the bond lengths and displacement parameters of the disordered units to ensure that they displayed approximately normal behaviour.

For all structures, $\mathrm{H}$ atoms bound to $\mathrm{C}$ atoms were placed in the expected geometric positions and treated in riding mode, with $\mathrm{C}-\mathrm{H}=0.95 \AA$ and $U_{\text {iso }}(\mathrm{H})=1.2 U_{\text {eq }}(\mathrm{C})$ for $\mathrm{C}-\mathrm{H}$ groups, and $\mathrm{C}-\mathrm{H}=0.98 \AA$ and $U_{\text {iso }}(\mathrm{H})=1.5 U_{\text {eq }}(\mathrm{C})$ for $\mathrm{CH}_{3}$ groups. $\mathrm{H}$ atoms bound to $\mathrm{N}$ or $\mathrm{O}$ atoms were located by difference synthesis and placed accordingly. For (III) and (IV), H atoms bound to $\mathrm{N}$ atoms were refined freely and isotropically. For (V), the $\mathrm{N}-\mathrm{H}$ distances were restrained to 0.88 (1) $\AA$ A. All water $\mathrm{H}$ atoms were restrained such that $\mathrm{O}-\mathrm{H}=0.88$ (1) $\AA$ and $\mathrm{H} \cdots \mathrm{H}=1.33(2) \AA$. For the water $\mathrm{H}$ atoms of $(\mathrm{V})$ and the $\mathrm{H}$ atoms of the disordered groups, $U_{\text {iso }}$ values were allowed to 
Table 1

Experimental details.

(I) (II)

Crystal data

Chemical formula

$\left[\mathrm{Na}_{2}\left(\mathrm{C}_{12} \mathrm{H}_{8} \mathrm{~N}_{2} \mathrm{O}_{6} \mathrm{~S}_{2}\right)\left(\mathrm{H}_{2} \mathrm{O}\right)_{4}\right]$

$M_{\mathrm{r}}$

Crystal system, space group

Temperature $(\mathrm{K})$

$a, b, c(\AA)$

$\alpha, \beta, \gamma\left({ }^{\circ}\right)$

$V\left(\AA^{3}\right)$

Z

Radiation type

$\mu\left(\mathrm{mm}^{-1}\right)$

Crystal size (mm)

Data collection

Diffractometer

Absorption correction

$T_{\min }, T_{\max }$

No. of measured, independent and observed $[I>2 \sigma(I)]$ reflections

$R_{\text {int }}$
$(\sin \theta / \lambda)_{\max }\left(\AA^{-1}\right)$

\subsection{7}

Monoclinic, $C 2 / c$

130

21.2141 (9), 5.5370 (3), 15.3045 (8)

90, $90.310(2), 90$

1797.68 (16)

$$
4
$$

Mo $K \alpha$

0.40

$0.50 \times 0.32 \times 0.08$

Nonius KappaCCD

$-$

$3500,1865,1414$

0.035

0.629

$0.038,0.090,1.04$

1865

145

6

$\mathrm{H}$ atoms treated by a mixture of independent and constrained refinement
$\left[\mathrm{Ca}\left(\mathrm{C}_{12} \mathrm{H}_{8} \mathrm{~N}_{2} \mathrm{O}_{6} \mathrm{~S}_{2}\right)\left(\mathrm{H}_{2} \mathrm{O}\right)_{4}\right]$

452.47

Triclinic, $P \overline{1}$

123

$6.3875(2), 6.7470(2)$,

$11.3030(5)$

94.289 (2), 103.160 (2),

$108.456(2)$

$444.21(3)$

1

Mo $K \alpha$

0.65

$0.50 \times 0.25 \times 0.05$

Nonius Kappa CCD

$-$

3837, 2038, 1775

0.020

0.651

$0.027,0.070,1.05$

2038

140

6

$\mathrm{H}$ atoms treated by a mixture of independent and constrained refinement

$0.40,-0.46$
(III)

$\left[\mathrm{Na}\left(\mathrm{C}_{12} \mathrm{H}_{10} \mathrm{~N}_{3} \mathrm{O}_{6} \mathrm{~S}_{2}\right)\left(\mathrm{H}_{2} \mathrm{O}\right)_{2}\right]$-$2 \mathrm{H}_{2} \mathrm{O}$

451.40

Monoclinic, $P 2_{1} / c$

150

13.9454 (18), 19.517 (3), 6.9014 (9)

90, 93.838 (2), 90

$1874.2(4)$

4

Synchrotron, $\lambda=0.6775 \AA$

0.32

$0.50 \times 0.01 \times 0.01$

Bruker APEXII

Multi-scan (SADABS; Bruker, 2012)

$0.676,1.000$

15360, 3531, 2772

0.049

0.608

$0.040,0.107,1.04$

3531

311

15

$\mathrm{H}$ atoms treated by a mixture of independent and constrained refinement

$0.35,-0.44$

$\Delta \rho_{\max }, \Delta \rho_{\min }\left(\mathrm{e} \AA^{-3}\right)$ $0.43,-0.32$

(V)

Crystal data

Chemical formula

$M_{\mathrm{r}}$

Crystal system, space group

Temperature (K)

$a, b, c(\AA)$

$\alpha, \beta, \gamma\left({ }^{\circ}\right)$

$V\left(\AA^{3}\right)$

$Z$

Radiation type

$\mu\left(\mathrm{mm}^{-1}\right)$

Crystal size (mm)

Data collection

Diffractometer

Absorption correction

$T_{\min }, T_{\max }$

No. of measured, independent and observed

$[I>2 \sigma(I)]$ reflections

$R_{\text {int }}$

$(\sin \theta / \lambda)_{\max }\left(\AA^{-1}\right)$

$\left[\mathrm{Mg}\left(\mathrm{H}_{2} \mathrm{O}\right)_{6}\right]\left(\mathrm{C}_{12} \mathrm{H}_{10} \mathrm{~N}_{3} \mathrm{O}_{6} \mathrm{~S}_{2}\right)_{2} \cdot 8 \mathrm{H}_{2} \mathrm{O}$
989.23
Monoclinic, $C 2 / c$
123
$36.896(3), 6.7806(4), 17.9140(12)$
$90,111.178(9), 90$
$4179.0(6)$
4
$\mathrm{Cu} \mathrm{K \alpha}$
3.12
$0.5 \times 0.05 \times 0.03$

Oxford Diffraction Gemini S

Multi-scan (CrysAlis PRO; Rigaku OD, 2019)

$0.572,1.000$

$7541,4093,3287$

0.039

0.621

$0.050,0.143,1.06$

4093

359

110

$\mathrm{H}$ atoms treated by a mixture of independent and constrained refinement

$0.80,-0.38$

$\Delta \rho_{\max }, \Delta \rho_{\min }\left(\mathrm{e}^{-3}\right)$

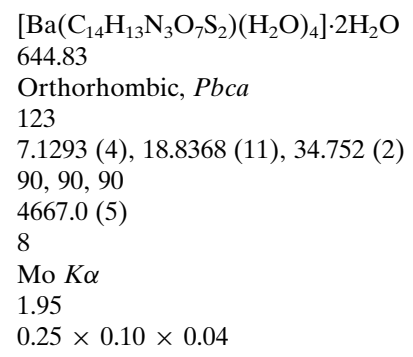

Nonius KappaCCD

Multi-scan (SADABS; Bruker, 2012)

$0.448,0.743$

7914, 4489, 3554

0.037

0.616

$0.042,0.096,1.15$

4489

344

20

$\mathrm{H}$ atoms treated by a mixture of independent and constrained refinement

$1.65,-1.23$

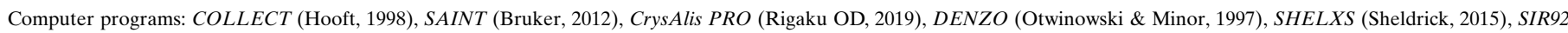
(Altomare et al., 1994), WinGX (Farrugia, 2012), Mercury (Macrae et al., 2020), ORTEP-3 (Farrugia, 2012) and SHELXL2014 (Sheldrick, 2015). 
ride on the parent $\mathrm{O}$ atom and for all other water $\mathrm{H}$ atoms, $U_{\text {iso }}$ values were allowed to refine freely.

\section{Results and discussion}

Previous work on the salt forms of monosulfonated dyes and pigments has shown that many structural features can be predicted from knowledge of the cation identity and the position of the sulfonate group (Kennedy et al., 2009, 2012). With respect to $L 1$ and the metal cations used herein, relevant observations on monosulfonated species with a similar meta relationship between the azo and $\mathrm{SO}_{3}$ groups are as follows. $\mathrm{Na}$ structures are expected to feature high-dimensionality coordination polymers with both $\mathrm{SO}_{3}$ and $\mathrm{H}_{2} \mathrm{O}$ groups bridging between $\mathrm{Na}$ centres. However, if metal-to-sulfonate bonds exist at all, then $\mathrm{Ca}$ structures should either be nonpolymeric entities or simple one-dimensional polymers with $\mathrm{H}_{2} \mathrm{O}$ ligands adopting only terminal positions. $L 2$ has both meta and para relationships between its azo and $\mathrm{SO}_{3}$ groups. Again extrapolation from what is known of monosulfonated azo salt forms would suggest that for $L 2$ an $\mathrm{Mg}$ species should be a solvent-separated ion-pair structure with no $\mathrm{Mg}-\mathrm{O}_{3} \mathrm{~S}$ bonds, whilst $\mathrm{Na}$ species should have a highdimensional coordination polymer structure similar to those predicted for an Na salt of $L 1$ above (Kennedy et al., 2004). In all cases, the overall packing should feature simple alternating layers of hydrophilic groups (e.g. cations, $\mathrm{SO}_{3}$ and $\mathrm{H}_{2} \mathrm{O}$ ) and hydrophobic groups (the aryl azo body of the anions) (Kennedy et al., 2009).

The structure of disulfonate (I) fits well with these predictions from monosulfonates. It is indeed a three-dimensional coordination polymer with both $\mathrm{SO}_{3}$ and $\mathrm{H}_{2} \mathrm{O}$ groups bridging between metal centres, and it forms a simple layered structure as expected. In more detail, the asymmetric unit of (I) contains two separate Na sites, both of which occupy special positions ( $\mathrm{Na} 1$ sits on a twofold axis and $\mathrm{Na} 2$ on a centre of symmetry in the space group $C 2 / c$ ). It also contains two water ligands and

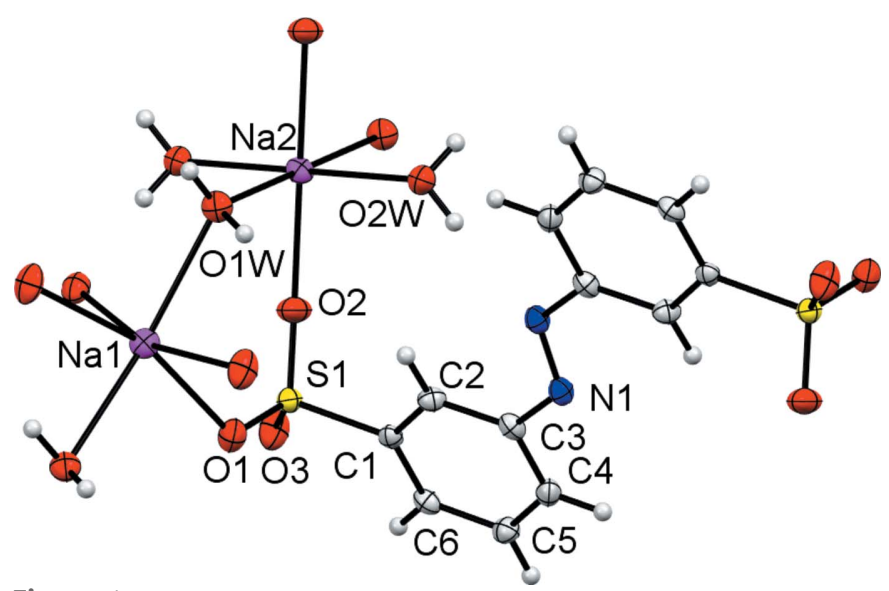

Figure 1

The asymmetric unit of (I) expanded to show the coordination shell about $\mathrm{Na} 1$ and $\mathrm{Na} 2$, and the conformation of $L 1$. Non-H atoms are shown as $50 \%$ probability displacement ellipsoids and $\mathrm{H}$ atoms are drawn as small spheres of arbitrary size.
Table 2

Selected geometric parameters $\left(\AA,^{\circ}\right)$ for $(\mathrm{I})$.

\begin{tabular}{|c|c|c|c|}
\hline $\mathrm{Na} 1-\mathrm{O}^{\mathrm{i}}$ & 2.4174 (19) & $\mathrm{Na} 2-\mathrm{O} 2$ & 2.3340 (18) \\
\hline $\mathrm{Na} 1-\mathrm{O}^{\mathrm{ii}}$ & 2.4175 (19) & $\mathrm{Na} 2-\mathrm{O} 1 W$ & $2.3688(17)$ \\
\hline $\mathrm{Na} 1-\mathrm{O} 1$ & $2.419(2)$ & $\mathrm{Na} 2-\mathrm{O} 1 W^{\mathrm{iv}}$ & $2.3688(17)$ \\
\hline $\mathrm{Na} 1-\mathrm{O} 1^{\mathrm{iii}}$ & $2.419(2)$ & $\mathrm{Na} 2-\mathrm{O} 2 W^{\mathrm{iv}}$ & $2.4480(17)$ \\
\hline $\mathrm{Na} 1-\mathrm{O} 1 W^{\mathrm{iii}}$ & $2.5019(18)$ & $\mathrm{Na} 2-\mathrm{O} 2 W$ & $2.4480(17)$ \\
\hline $\mathrm{Na} 1-\mathrm{O} 1 W$ & $2.5019(18)$ & $\mathrm{N} 1-\mathrm{N} 1^{\mathrm{v}}$ & $1.262(4)$ \\
\hline $\mathrm{Na} 2-\mathrm{O} 2^{\mathrm{iv}}$ & $2.3340(18)$ & $\mathrm{N} 1-\mathrm{C} 3$ & $1.431(3)$ \\
\hline $\mathrm{O} 3^{\mathrm{i}}-\mathrm{Na} 1-\mathrm{O} 3^{\mathrm{ii}}$ & $100.81(10)$ & $\mathrm{O} 2^{\mathrm{iv}}-\mathrm{Na} 2-\mathrm{O} 2$ & 180.0 \\
\hline $\mathrm{O} 3^{\mathrm{i}}-\mathrm{Na} 1-\mathrm{O} 1$ & $85.49(6)$ & $\mathrm{O} 2^{\mathrm{iv}}-\mathrm{Na} 2-\mathrm{O} 1 W$ & $91.49(7)$ \\
\hline $\mathrm{O} 3^{\mathrm{ii}}-\mathrm{Na} 1-\mathrm{O} 1$ & $163.62(6)$ & $\mathrm{O} 2-\mathrm{Na} 2-\mathrm{O} 1 W$ & $88.51(7)$ \\
\hline $\mathrm{O} 1-\mathrm{Na} 1-\mathrm{O} 1^{\mathrm{iii}}$ & $92.59(9)$ & $\mathrm{O} 1 W-\mathrm{Na} 2-\mathrm{O} 1 W^{\mathrm{iv}}$ & 180.0 \\
\hline $\mathrm{O} 3^{\mathrm{i}}-\mathrm{Na} 1-\mathrm{O} 1 W^{\mathrm{iii}}$ & $86.52(7)$ & $\mathrm{O} 2-\mathrm{Na} 2-\mathrm{O} 2 W^{\mathrm{iv}}$ & $98.30(6)$ \\
\hline $\mathrm{O} 3^{\mathrm{ii}}-\mathrm{Na} 1-\mathrm{O} 1 W^{\mathrm{iii}}$ & $75.28(6)$ & $\mathrm{O} 1 W-\mathrm{Na} 2-\mathrm{O} 2 W^{\mathrm{iv}}$ & $87.42(6)$ \\
\hline $\mathrm{O} 1-\mathrm{Na} 1-\mathrm{O} 1 W^{\mathrm{iii}}$ & $90.17(6)$ & $\mathrm{O} 2-\mathrm{Na} 2-\mathrm{O} 2 W$ & $81.70(6)$ \\
\hline $\mathrm{O} 1-\mathrm{Na} 1-\mathrm{O} 1 W$ & $109.77(6)$ & $\mathrm{O} 1 W-\mathrm{Na} 2-\mathrm{O} 2 W$ & $92.58(6)$ \\
\hline $\mathrm{O} 1 W^{\mathrm{iii}}-\mathrm{Na} 1-\mathrm{O} 1 W$ & $151.40(10)$ & & \\
\hline
\end{tabular}

Symmetry codes: (i) $x, y-1, z$; (ii) $-x, y-1,-z+\frac{1}{2}$; (iii) $-x, y,-z+\frac{1}{2}$; (iv) $-x,-y+1,-z+1 ;(\mathrm{v})-x+\frac{1}{2},-y+\frac{1}{2},-z+1$.

Table 3

Hydrogen-bond geometry $\left(\AA,^{\circ}\right)$ for (I).

\begin{tabular}{lllll}
\hline$D-\mathrm{H} \cdots A$ & $D-\mathrm{H}$ & $\mathrm{H} \cdots A$ & $D \cdots A$ & $D-\mathrm{H} \cdots A$ \\
\hline $\mathrm{O} 1 W-\mathrm{H} 2 W \cdots \mathrm{O} 2 W^{\mathrm{i}}$ & $0.87(1)$ & $2.07(2)$ & $2.919(3)$ & $163(3)$ \\
$\mathrm{O} 1 W-\mathrm{H} 1 W \cdots \mathrm{O} 2^{\mathrm{i}}$ & $0.87(1)$ & $2.29(2)$ & $3.044(3)$ & $145(3)$ \\
$\mathrm{O} 1 W-\mathrm{H} 1 W \cdots 3^{\mathrm{i}}$ & $0.87(1)$ & $2.32(3)$ & $3.005(3)$ & $136(3)$ \\
$\mathrm{O}^{2} W-\mathrm{H} 3 W \cdots \mathrm{O} 1^{\mathrm{iii}}$ & $0.87(1)$ & $1.94(1)$ & $2.807(2)$ & $175(3)$ \\
$\mathrm{O} W-\mathrm{H} 4 W \cdots \mathrm{N} 1^{\mathrm{vi}}$ & $0.87(1)$ & $2.22(1)$ & $3.076(3)$ & $168(3)$ \\
\hline
\end{tabular}

Symmetry codes: (i) $x, y-1, z$; (iii) $-x, y,-z+\frac{1}{2}$; (vi) $x-\frac{1}{2}, y+\frac{1}{2}, z$.

half of an $L 1$ dianion. A crystallographic centre of symmetry is located at the centre of the azo bond, giving a planar dianion with mutually anti $\mathrm{SO}_{3}$ groups (Fig. 1). As can be seen from Table 2, each $\mathrm{Na}$ centre is approximately octahedral, with $\mathrm{Na} 1$

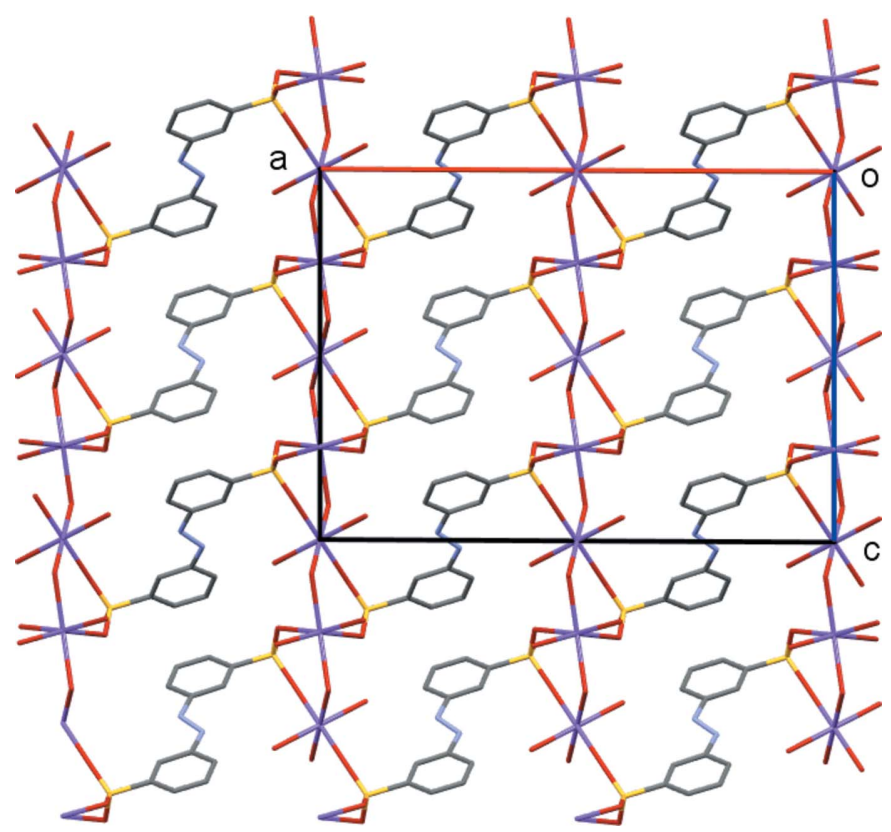

Figure 2

Packing diagram of (I), viewed down the $b$ axis. Note the alternating hydrophobic and hydrophilic layers that lie parallel to the $b c$ plane. 


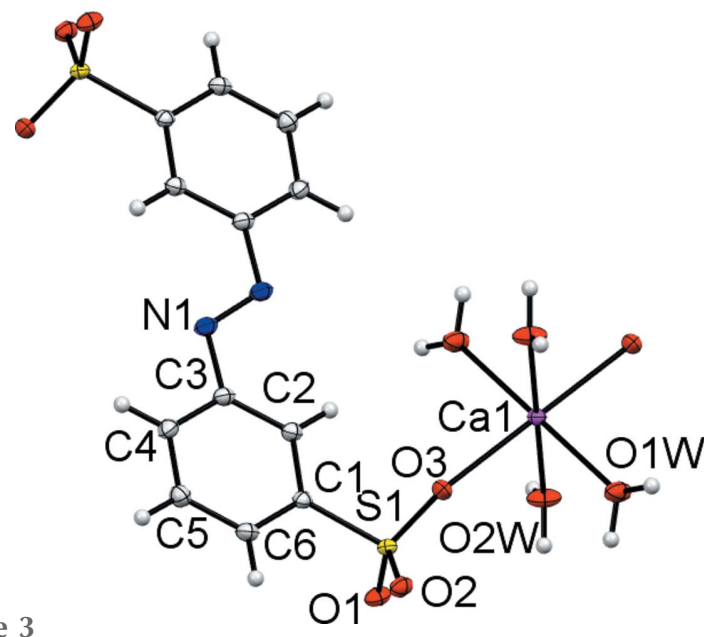

Figure 3

The asymmetric unit of (II) expanded to show the coordination shell about $\mathrm{Ca} 1$ and the conformation of $L 1$. Non-H atoms are shown as $50 \%$ probability displacement ellipsoids and $\mathrm{H}$ atoms are drawn as small spheres of arbitrary size.

bonding to two bridging water molecules and to four $\mathrm{O}$ atoms of four different $L 1$ dianions. $\mathrm{Na} 2$ bonds to two $\mathrm{O}$ atoms of two $L 1$ dianions and to four water ligands, two of which form terminal bonds and two of which bridge to Na1 centres. Note that the bond lengths involving $\mathrm{Na} 1$ are systematically longer than those of $\mathrm{Na} 2$ [ranges $2.4174(19)-2.5019$ (18) and 2.3340 (18)-2.4480 (17) ^ for Na1 and Na2, respectively]. The $\mathrm{SO}_{3}$ units each form three bonds to $\mathrm{Na}$ centres, one from each $\mathrm{O}$ atom. Within the hydrophilic layers, pairs of $\mathrm{Na} 1$ centres are linked by eight-membered $[\mathrm{NaOSO}]_{2}$ rings, whilst the $\mathrm{Na} 1$ and $\mathrm{Na} 2$ centres are linked by six-membered [ $\mathrm{NaOSONaO}$ ] rings, with both bridging sulfonate and water ligands. As can be seen from Fig. 2, the layers expand parallel to the $b c$ plane, with the disulfonate dianions bridging between neighbouring hydrophilic layers to give the overall three-dimensional coordination polymer. The hydrogen-bond details for (I) are given in Table 3.

The asymmetric unit of (II) contains half of an $L 1$ dianion, two water ligands and a $\mathrm{Ca}$ site. Both the $\mathrm{Ca} 1$ site and the centre of the azo $\mathrm{N}=\mathrm{N}$ bond occupy crystallographic inversion centres. As with (I), this gives a planar dianion with anti $\mathrm{SO}_{3}$ groups and an octahedral metal centre (Fig. 3 and Table 4). Ca1 forms bonds to $\mathrm{O}$ atoms from two trans $\mathrm{SO}_{3}$ groups and to four terminal water ligands. Each $\mathrm{SO}_{3}$ group makes a single $\mathrm{Ca}-\mathrm{O}$ bond and thus the disulfonate dianion
Table 4

Selected geometric parameters $\left(\AA,^{\circ}\right)$ for (II).

\begin{tabular}{|c|c|c|c|}
\hline $\mathrm{Ca} 1-\mathrm{O} 3$ & $2.3050(11)$ & $\mathrm{Ca} 1-\mathrm{O} 2 W^{\mathrm{i}}$ & $2.3385(12)$ \\
\hline $\mathrm{Ca} 1-\mathrm{O}^{\mathrm{i}}$ & $2.3051(11)$ & $\mathrm{Ca} 1-\mathrm{O} 2 W$ & $2.3385(12)$ \\
\hline $\mathrm{Ca} 1-\mathrm{O} 1 W$ & $2.3235(12)$ & $\mathrm{N} 1-\mathrm{N} 1^{\mathrm{ii}}$ & $1.256(3)$ \\
\hline $\mathrm{Ca} 1-\mathrm{O} 1 W^{\mathrm{i}}$ & $2.3236(12)$ & $\mathrm{N} 1-\mathrm{C} 3$ & $1.432(2)$ \\
\hline $\mathrm{O} 3-\mathrm{Ca} 1-\mathrm{O}^{\mathrm{i}}$ & 180.0 & $\mathrm{O} 1 W-\mathrm{Ca} 1-\mathrm{O} 2 W^{\mathrm{i}}$ & $90.52(5)$ \\
\hline $\mathrm{O} 3-\mathrm{Ca} 1-\mathrm{O} 1 W$ & $87.66(4)$ & $\mathrm{O} 3-\mathrm{Ca} 1-\mathrm{O} 2 W$ & $86.93(5)$ \\
\hline $\mathrm{O} 3-\mathrm{Ca} 1-\mathrm{O} 1 W^{\mathrm{i}}$ & $92.34(4)$ & $\mathrm{O} 1 W-\mathrm{Ca} 1-\mathrm{O} 2 W$ & $89.48(5)$ \\
\hline $\mathrm{O} 1 W-\mathrm{Ca} 1-\mathrm{O} 1 W^{\mathrm{i}}$ & $180.00(6)$ & $\mathrm{O} 2 W^{\mathrm{i}}-\mathrm{Ca} 1-\mathrm{O} 2 W$ & 180.0 \\
\hline $\mathrm{O} 3-\mathrm{Ca} 1-\mathrm{O} 2 W^{\mathrm{i}}$ & $93.07(4)$ & & \\
\hline
\end{tabular}

Table 5

Hydrogen-bond geometry $\left(\AA{ }^{\circ}{ }^{\circ}\right.$ ) for (II).

\begin{tabular}{|c|c|c|c|c|}
\hline$D-\mathrm{H} \cdots A$ & $D-\mathrm{H}$ & $\mathrm{H} \cdots A$ & $D \cdots A$ & $D-\mathrm{H} \cdots A$ \\
\hline $\mathrm{O} 1 W-\mathrm{H} 1 W \cdots \mathrm{O} 2^{\mathrm{iii}}$ & $0.87(1)$ & $2.01(1)$ & $2.8521(17)$ & $162(2)$ \\
\hline $\mathrm{O} 1 W-\mathrm{H} 2 W \cdots \mathrm{O} 1^{\mathrm{iv}}$ & $0.86(1)$ & $2.00(1)$ & $2.8454(17)$ & $165(2)$ \\
\hline $\mathrm{O} 2 W-\mathrm{H} 3 W \cdots \mathrm{O} 2^{\mathrm{iv}}$ & $0.86(1)$ & $1.95(1)$ & $2.8119(16)$ & $174(2)$ \\
\hline $\mathrm{O} 2 W-\mathrm{H} 4 W \cdots \mathrm{O} 1^{\mathrm{v}}$ & $0.86(1)$ & $1.94(1)$ & $2.7907(16)$ & $168(2)$ \\
\hline
\end{tabular}

Symmetry codes: (iii) $-x+2,-y+1,-z+1$; (iv) $-x+2,-y+2,-z+1$; (v) $-x+1$, $-y+2,-z+1$.

links Ca centres into a one-dimensional coordination polymer (Fig. 4). These features combine to give the layered structure shown in Fig. 5. Within the hydrophilic layers, hydrogen bonding between the water ligands and the two noncoordinating $\mathrm{O}$ atoms of $\mathrm{SO}_{3}$ link neighbouring coordination chains (Table 5). Thus, structure (II) also follows the rules proposed for monosulfonated azo dye salts. There are $\mathrm{Ca}-\mathrm{O}_{3} \mathrm{~S}$ bonds, but these are relatively few in number and, even with the twoheaded nature of the disulfonate ligand, they combine to give only a one-dimensional coordination polymer. The $\mathrm{H}_{2} \mathrm{O}$ ligands take no part in bridging between metal centres and the overall packing motif is one of simple alternating hydrophobic and hydrophilic layers.

Structure (III) was obtained from aqueous recrystallization of the commercial product called 'Acid Yellow 9, monosodium salt'. An interesting problem here was to discover the protonation site. The crystal structures of three acidic sulfonated azobenzene-based dyes with amino substituents are known. 4-Aminoazobenzene-4'-sulfonic acid crystallizes with protonation of the amino group, giving an $-\mathrm{NH}_{3}$-bearing zwitterion, whilst the other two known structures crystallize with protonation of the azo $\mathrm{N}$ atom furthest from the neutral $-\mathrm{NH}_{2}$ group (Lu et al., 2009; Miyano et al., 2016; Kennedy et al.,

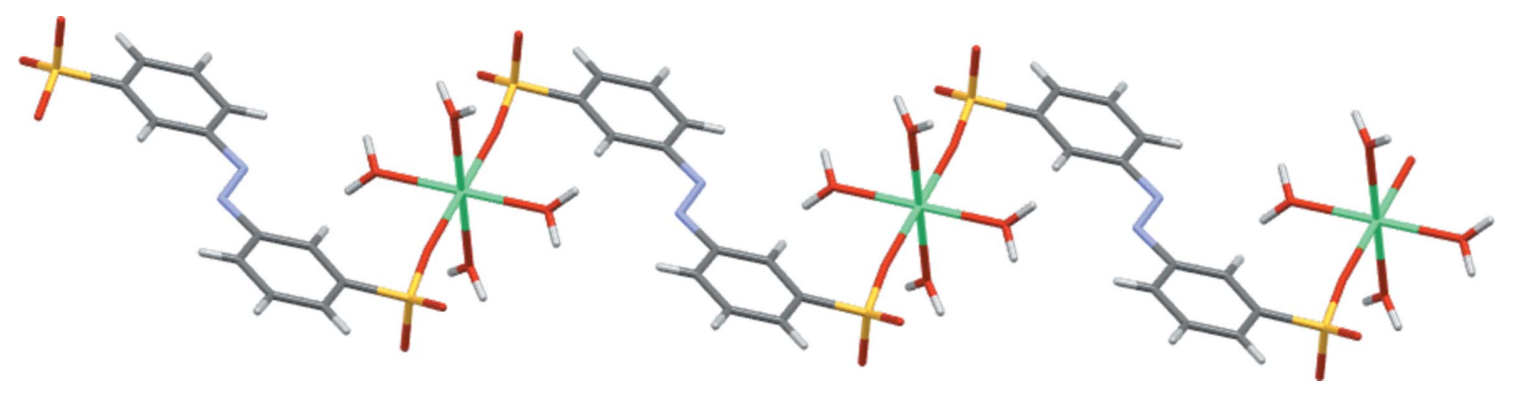

Figure 4

Part of the one-dimensional coordination polymer of (II). 
Table 6

Selected geometric parameters $\left(\AA{ }^{\circ}\right)$ for (III).

\begin{tabular}{lrlr}
\hline $\mathrm{Na} 1-\mathrm{O} 1 W$ & $2.275(2)$ & $\mathrm{N} 1-\mathrm{N} 2$ & $1.294(3)$ \\
$\mathrm{Na} 1-\mathrm{O} 2 W^{\mathrm{i}}$ & $2.335(2)$ & $\mathrm{N} 1-\mathrm{C} 4$ & $1.411(3)$ \\
$\mathrm{Na} 1-\mathrm{O} 2 W$ & $2.369(2)$ & $\mathrm{N} 2-\mathrm{C} 7$ & $1.341(3)$ \\
$\mathrm{Na} 1-\mathrm{O} 6$ & $2.409(2)$ & $\mathrm{N} 3-\mathrm{C} 10$ & $1.316(3)$ \\
$\mathrm{Na} 1-\mathrm{O} 6{ }^{\mathrm{i}}$ & $2.425(2)$ & & \\
& & & \\
$\mathrm{O} 1 W-\mathrm{Na} 1-\mathrm{O} 2 W^{\mathrm{i}}$ & $154.18(9)$ & $\mathrm{O} 2 W-\mathrm{Na} 1-\mathrm{O} 6$ & $75.46(7)$ \\
$\mathrm{O} 1 W-\mathrm{Na} 1-\mathrm{O} 2 W$ & $96.67(9)$ & $\mathrm{O} 1 W-\mathrm{Na} 1-\mathrm{O} 6^{\mathrm{i}}$ & $85.06(8)$ \\
$\mathrm{O} 2 W^{\mathrm{i}}-\mathrm{Na} 1-\mathrm{O} 2 W$ & $95.44(7)$ & $\mathrm{O}^{\mathrm{i}} W^{\mathrm{i}}-\mathrm{Na} 1-\mathrm{O}^{\mathrm{i}}$ & $75.79(7)$ \\
$\mathrm{O} 1 W-\mathrm{Na} 1-\mathrm{O} 6$ & $88.23(8)$ & $\mathrm{O} 2 W-\mathrm{Na} 1-\mathrm{O}^{\mathrm{i}}$ & $159.34(8)$ \\
$\mathrm{O} 2 W^{\mathrm{i}}-\mathrm{Na} 1-\mathrm{O} 6$ & $116.93(8)$ & $\mathrm{O}^{2}-\mathrm{Na} 1-6^{\mathrm{i}}$ & $125.20(8)$ \\
\hline
\end{tabular}

Symmetry code: (i) $x,-y+\frac{1}{2}, z+\frac{1}{2}$.

Table 7

Hydrogen-bond geometry $\left(\AA,^{\circ}\right)$ for (III).

\begin{tabular}{|c|c|c|c|c|}
\hline$D-\mathrm{H} \cdots A$ & $D-\mathrm{H}$ & $\mathrm{H} \cdots A$ & $D \cdots A$ & $D-\mathrm{H} \cdots A$ \\
\hline $\mathrm{N} 1-\mathrm{H} 1 \mathrm{~N} \cdots \mathrm{O} 3 W^{\mathrm{ii}}$ & $0.84(3)$ & $2.10(3)$ & $2.878(3)$ & $153(3)$ \\
\hline $\mathrm{N} 3-\mathrm{H} 2 \mathrm{~N} \cdots \mathrm{O} 4 W$ & $0.82(3)$ & $2.04(3)$ & $2.847(5)$ & $170(3)$ \\
\hline $\mathrm{N} 3-\mathrm{H} 2 \mathrm{~N} \cdots \mathrm{O} 5 \mathrm{~W}$ & $0.82(3)$ & $2.05(4)$ & 2.843 (11) & $163(3)$ \\
\hline 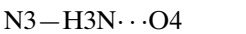 & $0.81(3)$ & $2.60(3)$ & $3.084(3)$ & $120(3)$ \\
\hline $\mathrm{N} 3-\mathrm{H} 3 \mathrm{~N} \cdots \mathrm{O} 4^{\mathrm{iii}}$ & $0.81(3)$ & $2.20(3)$ & $2.923(3)$ & $150(3)$ \\
\hline $\mathrm{N} 3-\mathrm{H} 3 \mathrm{~N} \cdots \mathrm{O} 5$ & $0.81(3)$ & $2.61(3)$ & 3.095 (3) & $120(3)$ \\
\hline $\mathrm{O} 1 W-\mathrm{H} 1 W \cdots \mathrm{O} 5^{\mathrm{iv}}$ & $0.88(1)$ & $1.93(2)$ & $2.773(3)$ & $160(4)$ \\
\hline $\mathrm{O} 1 W-\mathrm{H} 2 W \cdots \mathrm{O} 4^{\mathrm{i}}$ & $0.88(1)$ & $1.93(2)$ & $2.756(3)$ & $157(4)$ \\
\hline $\mathrm{O} 2 W-\mathrm{H} 3 W \cdots \mathrm{O}^{\mathrm{v}}$ & $0.88(1)$ & $1.90(1)$ & $2.774(2)$ & $176(4)$ \\
\hline $\mathrm{O} 2 W-\mathrm{H} 4 W \cdots \mathrm{O} 1^{\mathrm{vi}}$ & $0.88(1)$ & $1.88(1)$ & $2.746(3)$ & $171(3)$ \\
\hline $\mathrm{O} 3 W-\mathrm{H} 5 W \cdots \mathrm{O} 2^{\mathrm{vii}}$ & $0.86(1)$ & $2.03(1)$ & $2.866(3)$ & $164(3)$ \\
\hline $\mathrm{O} 3 W-\mathrm{H} 6 W \cdots \mathrm{O} 3^{\mathrm{vi}}$ & $0.87(1)$ & $2.22(1)$ & $3.081(3)$ & $171(3)$ \\
\hline $\mathrm{O} 4 W-\mathrm{H} 7 W \cdots \mathrm{O} 3^{\mathrm{i}}$ & $0.88(1)$ & $2.02(1)$ & $2.887(5)$ & $175(4)$ \\
\hline $\mathrm{O} 4 W-\mathrm{H} 8 W \cdots \mathrm{O} 1^{\mathrm{iv}}$ & $0.88(1)$ & $1.97(1)$ & $2.846(5)$ & $173(5)$ \\
\hline $\mathrm{O} 5 W-\mathrm{H} 9 W \cdots \mathrm{O} 3^{\mathrm{i}}$ & $0.88(1)$ & $2.08(2)$ & 2.947 (13) & $170(10)$ \\
\hline $\mathrm{O} 5 W-\mathrm{H} 10 W \cdots \mathrm{O} 1^{\mathrm{iv}}$ & $0.88(1)$ & $1.89(2)$ & $2.765(9)$ & $171(10)$ \\
\hline
\end{tabular}

Symmetry codes: (i) $x,-y+\frac{1}{2}, z+\frac{1}{2}$; (ii) $x-1, y, z$; (iii) $-x,-y+1,-z$; (iv) $x,-y+\frac{1}{2}, z-\frac{1}{2}$; (v) $-x,-y,-z$; (vi) $-x, y+\frac{1}{2},-z+\frac{1}{2}$; (vii) $-x,-y,-z+1$.

2020). The azo group is the commonest protonation site for the free acid forms of sulfonated azo dyes that do not bear a more basic substituent (Kennedy et al., 2001, 2020). The asymmetric unit of (III) was found to contain an Na centre, a monoanionic $L 2$ ligand with protonation at azo atom N1, two

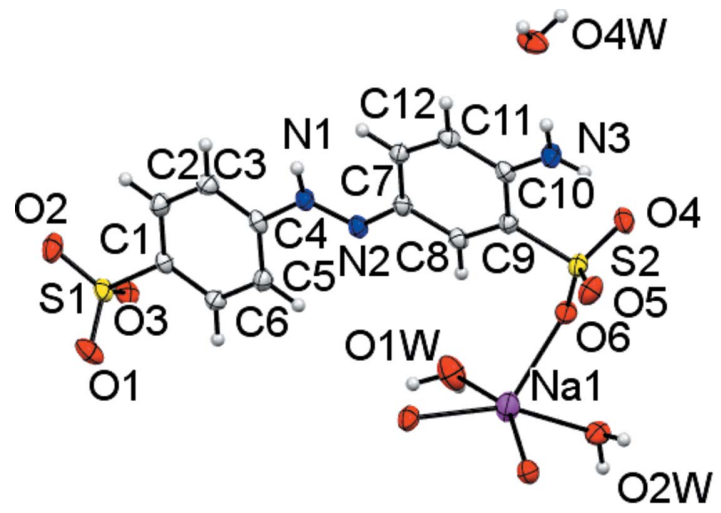

Figure 6

The asymmetric unit of (III) expanded to show the coordination shell about Na1. The minor-disorder component at $\mathrm{O} 4 \mathrm{~W}$ is not shown. Non-H atoms are shown as $50 \%$ probability displacement ellipsoids and $\mathrm{H}$ atoms are drawn as small spheres of arbitrary size.

metal-coordinated water ligands and two non-bound water molecules, one of which is disordered (Fig. 6). Unusually for an Na salt of an aryl sulfonate, only one of the six independent $\mathrm{SO}_{3} \mathrm{O}$ atoms is involved in bonding to $\mathrm{Na}$. This $\mathrm{Na} 1-\mathrm{O} 6$ interaction involves the $\mathrm{SO}_{3}$ group meta to the azo bond. Na1 exists in a distorted square-pyramidal and hence five-coordinate environment, where one bond is to a terminal water ligand and the other four bonds (from two water ligands and two $\mathrm{SO}_{3}$ groups) all bridge to neighbouring $\mathrm{Na}$ centres (see Table 6 for geometric details). The $\mathrm{Na}-\mathrm{O}$ bond lengths of (III) [range 2.275 (2)-2.425 (2) §] are understandably shorter than those of the six-coordinate $\mathrm{Na}$ centres of (I). An interesting detail is that in (III) the Na-to- $\mathrm{OH}_{2}$ distances are shorter that the Na-to- $\mathrm{SO}_{3}$ distances. This is the opposite of the case in (I). The one-dimensional coordination polymers in (III) are formed by chains of $[\mathrm{Na} 1-\mathrm{O} 2 W-\mathrm{Na} 1-\mathrm{O} 6]$ rings

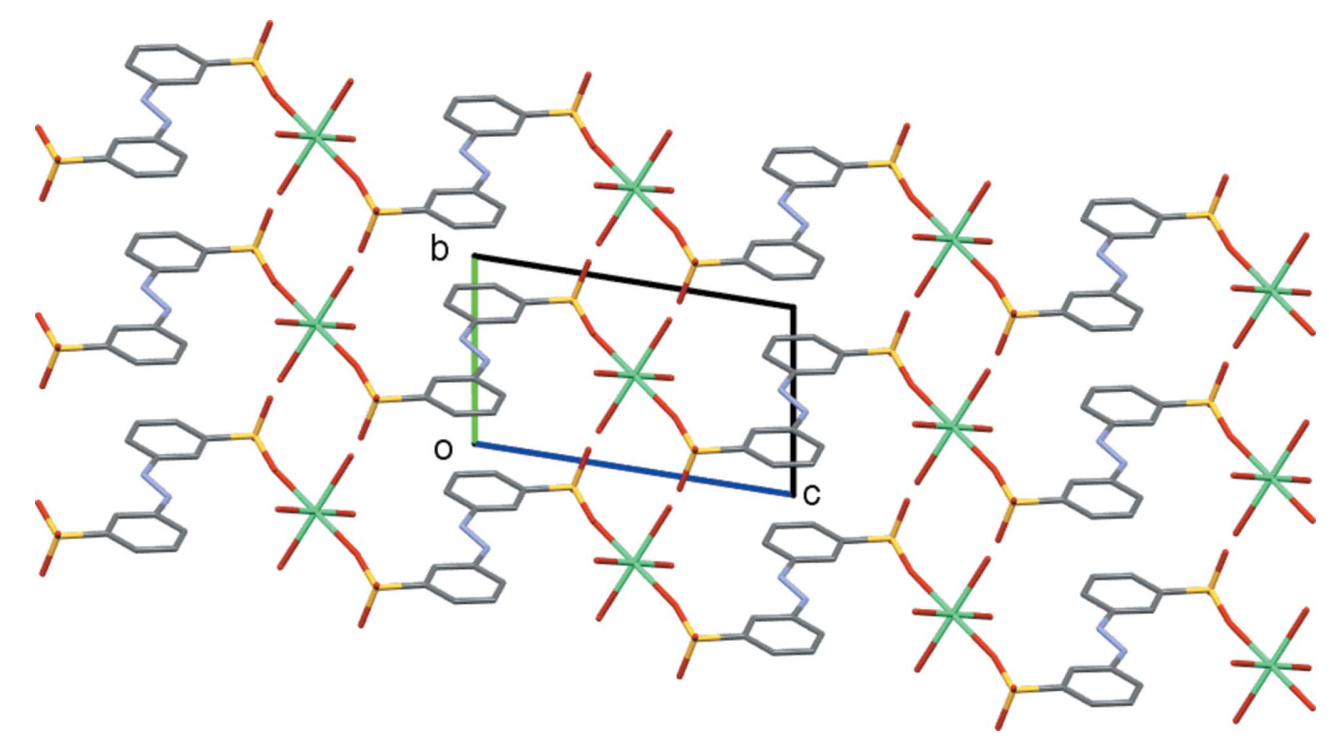

Figure 5

Packing diagram of (II), viewed down the $a$ axis. Note the alternating hydrophobic and hydrophilic layers that lie parallel to the $a b$ plane. 
Table 8

Selected geometric parameters $\left(\AA{ }^{\circ},{ }^{\circ}\right)$ for (IV).

\begin{tabular}{lclc}
\hline $\mathrm{Mg} 1-\mathrm{O} 2 W$ & $2.0322(19)$ & $\mathrm{N} 1-\mathrm{C} 4$ & $1.413(3)$ \\
$\mathrm{Mg} 1-\mathrm{O} 1 W$ & $2.0472(18)$ & $\mathrm{N} 2-\mathrm{C} 7$ & $1.342(4)$ \\
$\mathrm{Mg} 1-\mathrm{O} 3 W$ & $2.0769(19)$ & $\mathrm{N} 3-\mathrm{C} 10$ & $1.309(4)$ \\
$\mathrm{N} 1-\mathrm{N} 2$ & $1.294(4)$ & & \\
& & & \\
$\mathrm{O} 2 W^{\mathrm{i}}-\mathrm{Mg} 1-\mathrm{O} 2 W$ & 180.0 & $\mathrm{O} 1 W-\mathrm{Mg} 1-\mathrm{O} 3 W^{\mathrm{i}}$ & $88.07(8)$ \\
$\mathrm{O} 2 W^{\mathrm{i}}-\mathrm{Mg} 1-\mathrm{O} 1 W$ & $88.72(8)$ & $\mathrm{O} 2 W-\mathrm{Mg} 1-\mathrm{O} 3 W$ & $91.69(8)$ \\
$\mathrm{O} 2 W-\mathrm{Mg} 1-\mathrm{O} 1 W^{\mathrm{i}}$ & $91.28(8)$ & $\mathrm{O} 1 W-\mathrm{Mg} 1-\mathrm{O} 3 W$ & $91.93(8)$ \\
$\mathrm{O} 1 W-\mathrm{Mg} 1-\mathrm{O} 1 W^{\mathrm{i}}$ & 180.0 & $\mathrm{O} 3 W^{\mathrm{i}}-\mathrm{Mg} 1-\mathrm{O} 3 W$ & 180.0 \\
$\mathrm{O} 2 W-\mathrm{Mg} 1-\mathrm{O} 3 W^{\mathrm{i}}$ & $88.31(8)$ & & \\
\hline
\end{tabular}

Symmetry code: (i) $-x-\frac{1}{2},-y+\frac{1}{2},-z$.

Table 9

Hydrogen-bond geometry $\left(\AA,^{\circ}\right)$ for (IV).

\begin{tabular}{|c|c|c|c|c|}
\hline$D-\mathrm{H} \cdots A$ & $D-\mathrm{H}$ & $\mathrm{H} \cdots A$ & $D \cdots A$ & $D-\mathrm{H} \cdots A$ \\
\hline $\mathrm{N} 1-\mathrm{H} 1 \mathrm{~N} \cdots \mathrm{O} 7 \mathrm{~W}$ & $0.84(4)$ & $1.99(5)$ & $2.80(2)$ & $164(4)$ \\
\hline $\mathrm{N} 1-\mathrm{H} 1 \mathrm{~N} \cdots \mathrm{O} 8 \mathrm{~W}$ & $0.84(4)$ & $2.00(6)$ & $2.83(4)$ & $170(4)$ \\
\hline $\mathrm{N} 3-\mathrm{H} 2 \mathrm{~N} \cdots \mathrm{O} 5 W^{\mathrm{ii}}$ & $0.87(4)$ & $2.02(4)$ & $2.881(3)$ & $174(4)$ \\
\hline 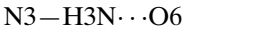 & $0.84(5)$ & $2.03(5)$ & $2.700(7)$ & $137(4)$ \\
\hline $\mathrm{N} 3-\mathrm{H} 3 \mathrm{~N} \cdots \mathrm{O} 6 \mathrm{~A}$ & $0.84(5)$ & $2.10(5)$ & $2.763(14)$ & $136(4)$ \\
\hline $\mathrm{O} 1 W-\mathrm{H} 1 W \cdots \mathrm{O} 3$ & $0.87(1)$ & $1.92(1)$ & $2.769(3)$ & $167(3)$ \\
\hline $\mathrm{O} 1 W-\mathrm{H} 2 W \cdots \mathrm{O} 1^{\mathrm{iii}}$ & $0.87(1)$ & $1.84(1)$ & $2.714(3)$ & $177(4)$ \\
\hline $\mathrm{O} 2 W-\mathrm{H} 3 W \cdots \mathrm{O} 4 W$ & $0.87(1)$ & $1.88(1)$ & $2.727(3)$ & $165(3)$ \\
\hline $\mathrm{O} 2 W-\mathrm{H} 4 W \cdots \mathrm{O} 2^{\mathrm{iv}}$ & $0.87(1)$ & $1.95(1)$ & $2.812(3)$ & $173(4)$ \\
\hline $\mathrm{O} 3 W-\mathrm{H} 5 W \cdots \mathrm{O} 4 W^{\mathrm{v}}$ & $0.87(1)$ & $1.85(1)$ & 2.707 (3) & $169(4)$ \\
\hline $\mathrm{O} 3 W-\mathrm{H} 6 W \cdots \mathrm{O}^{\mathrm{vi}}$ & $0.87(1)$ & $2.04(2)$ & $2.897(6)$ & $169(4)$ \\
\hline $\mathrm{O} 3 W-\mathrm{H} 6 W \cdots \mathrm{O} 6 A^{\mathrm{vi}}$ & $0.87(1)$ & $2.18(2)$ & $2.983(11)$ & $153(3)$ \\
\hline $\mathrm{O} 4 W-\mathrm{H} 8 W \cdots \mathrm{O} 5 W$ & $0.87(1)$ & $1.95(2)$ & $2.803(3)$ & $166(4)$ \\
\hline $\mathrm{O} 4 W-\mathrm{H} 7 W \cdots \mathrm{O} 6 W$ & $0.87(1)$ & $1.86(1)$ & $2.706(3)$ & $162(3)$ \\
\hline $\mathrm{O} 5 W-\mathrm{H} 10 W \cdots \mathrm{O} 2^{\mathrm{i}}$ & $0.87(1)$ & $2.16(3)$ & $2.829(3)$ & $133(3)$ \\
\hline $\mathrm{O} 5 W-\mathrm{H} 9 W \cdots \mathrm{O} 3^{\mathrm{vii}}$ & $0.87(1)$ & $1.99(1)$ & $2.820(3)$ & $160(3)$ \\
\hline $\mathrm{O} 5 W-\mathrm{H} 10 W \cdots \mathrm{O} 3^{\text {viii }}$ & $0.87(1)$ & $2.52(3)$ & $3.251(3)$ & $141(3)$ \\
\hline $\mathrm{O} 6 W-\mathrm{H} 11 W \cdots \mathrm{O} 4^{\mathrm{vi}}$ & $0.87(1)$ & $2.18(2)$ & $3.028(13)$ & $167(4)$ \\
\hline $\mathrm{O} 6 W-\mathrm{H} 11 W \cdots \mathrm{O} 4 A^{\mathrm{vi}}$ & $0.87(1)$ & $1.94(3)$ & $2.81(2)$ & $174(4)$ \\
\hline $\mathrm{O} 6 W-\mathrm{H} 12 W \cdots \mathrm{O} 5^{\mathrm{ix}}$ & $0.87(1)$ & $2.02(2)$ & $2.878(8)$ & $170(5)$ \\
\hline $\mathrm{O} 6 W-\mathrm{H} 12 W \cdots \mathrm{O} 5 A^{\mathrm{ix}}$ & $0.87(1)$ & $2.43(2)$ & $3.276(14)$ & $163(4)$ \\
\hline $\mathrm{O} 6 W-\mathrm{H} 12 W \cdots \mathrm{O} 6 A^{\mathrm{ix}}$ & $0.87(1)$ & $2.52(3)$ & $3.220(17)$ & $139(4)$ \\
\hline $\mathrm{O} 7 W-\mathrm{H} 13 W \cdots \mathrm{O}^{\mathrm{x}}$ & $0.89(1)$ & $2.35(6)$ & $2.89(2)$ & $119(5)$ \\
\hline $\mathrm{O} 7 W-\mathrm{H} 14 W \cdots \mathrm{O} 6 W^{\mathrm{ii}}$ & $0.88(1)$ & $2.52(3)$ & $3.354(18)$ & $159(5)$ \\
\hline $\mathrm{O} 7 W-\mathrm{H} 14 W \cdots \mathrm{O} 4^{\mathrm{xi}}$ & $0.88(1)$ & $2.35(5)$ & $2.92(2)$ & $123(4)$ \\
\hline $\mathrm{O} 8 W-\mathrm{H} 16 W \cdots \mathrm{O} 5 A^{\mathrm{x}}$ & 0.89 & 2.01 & $2.87(4)$ & 163 \\
\hline $\mathrm{O} 8 W-\mathrm{H} 15 W \cdots \mathrm{O} 4 A^{\mathrm{xi}}$ & 0.88 & 2.18 & $2.81(4)$ & 128 \\
\hline
\end{tabular}

Symmetry codes: (i) $-x-\frac{1}{2},-y+\frac{1}{2},-z$; (ii) $x+\frac{1}{2}, y-\frac{1}{2}, z$; (iii) $-x-\frac{1}{2}, y-\frac{1}{2},-z-\frac{1}{2}$; (iv) $-x-\frac{1}{2}, y+\frac{1}{2},-z-\frac{1}{2}$; (v) $x, y-1$, $z$; (vi) $x-\frac{1}{2},-y+\frac{1}{2}, z-\frac{1}{2}$; (vii) $-x-\frac{1}{2},-y+\frac{3}{2},-z$; (viii) $x,-y+1, z+\frac{1}{2}$; (ix) $x-\frac{1}{2},-y+\frac{3}{2}, z-\frac{1}{2}$; (x) $x,-y+1, z-\frac{1}{2}$; (xi) $x,-y, z-\frac{1}{2}$.

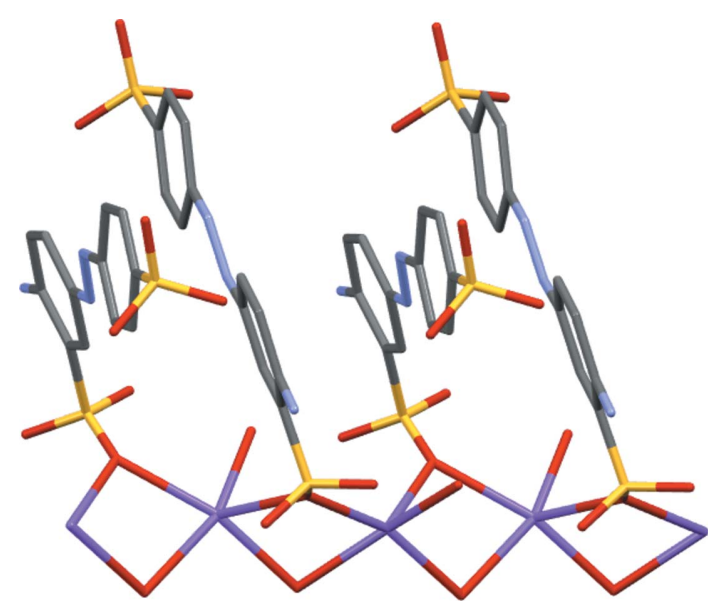

Figure 7

Part of the one-dimensional coordination polymer of (III).

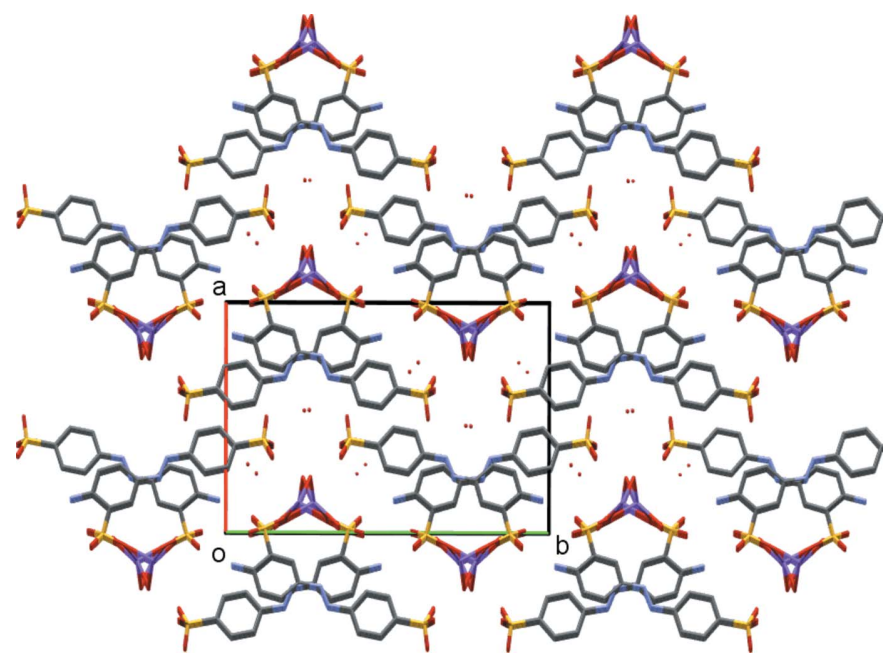

Figure 8

Packing diagram of (III), viewed down the $c$ axis. $\mathrm{H}$ atoms have been omitted for clarity. Note the hydrate channels that extend parallel to the $c$ axis.

and propagate parallel to the crystallographic $c$ direction. Each chain is asymmetric, with the $L 2$ anions on one side and the water ligands on the other (Fig. 7). This structure is thus unlike those of the monosulfonated azo Na salts as, despite having an extra potential metal-bonding group in the form of the second $\mathrm{SO}_{3}$ substituent, it does not form a higher-dimensional coordination polymer. A further difference is highlighted by Fig. 8, which shows that (III) is not a simple alternating layer structure. Note the hydrate channels running parallel to $c$. A reason for this may be that the simple alternate layering seen elsewhere is a function of the azo anions' approximation to linear spacers, with hydrophilic head and tail groups separated by a hydrophobic central region (Kennedy et al., 2009). As $L 2$ is protonated on the azo group, this introduces a hydrophilic group and strong hydrogen-bond donor to the centre of the azo anion. It may be that the need to provide a hydrogen-bond acceptor to this formally charged $\mathrm{N}-\mathrm{H}$ group is what breaks the otherwise common simple layering

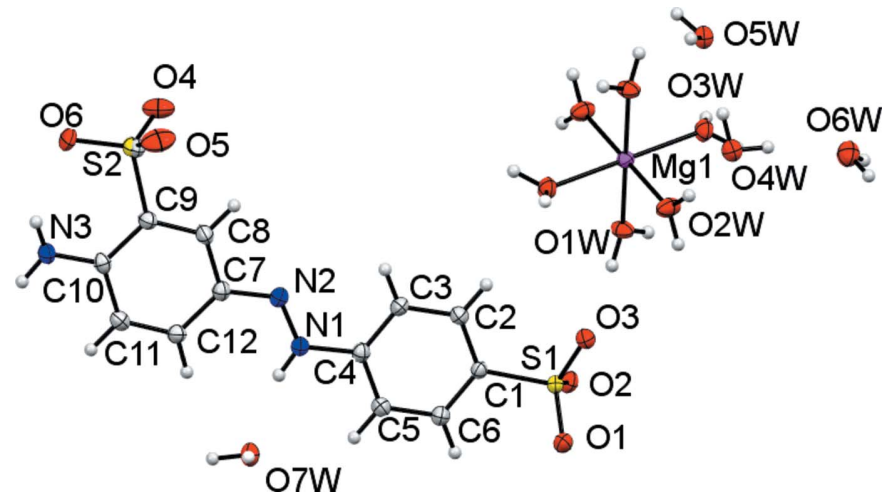

Figure 9

The asymmetric unit of (IV) expanded to show the coordination shell about Mg1. The minor-disorder components of the sulfonate groups of S2 and the $\mathrm{O} 7 \mathrm{~W}$ water molecule are not shown. Non-H atoms are shown as $50 \%$ probability displacement ellipsoids and $\mathrm{H}$ atoms are drawn as small spheres of arbitrary size. 
Table 10

Selected geometric parameters $\left(\AA{ }^{\circ}\right)$ for $(\mathrm{V})$.

\begin{tabular}{|c|c|c|c|}
\hline $\mathrm{Ba} 1-\mathrm{O} 2 W$ & $2.704(4)$ & $\mathrm{Ba} 1-\mathrm{O} 3 W$ & $2.911(4)$ \\
\hline $\mathrm{Ba} 1-\mathrm{O} 1 W$ & $2.747(4)$ & $\mathrm{Ba} 1-\mathrm{O} 3 W^{\mathrm{iii}}$ & 3.105 (4) \\
\hline $\mathrm{Ba} 1-\mathrm{O} 4^{\mathrm{i}}$ & $2.753(4)$ & $\mathrm{N} 1-\mathrm{N} 2$ & $1.277(6)$ \\
\hline $\mathrm{Ba} 1-\mathrm{O} 1$ & 2.759 (4) & $\mathrm{N} 1-\mathrm{C} 4$ & $1.426(6)$ \\
\hline $\mathrm{Ba} 1-\mathrm{O} 5^{\mathrm{ii}}$ & $2.788(4)$ & $\mathrm{N} 2-\mathrm{C} 7$ & $1.393(6)$ \\
\hline $\mathrm{Ba} 1-\mathrm{O} 4 W$ & $2.819(4)$ & $\mathrm{N} 3-\mathrm{C} 10$ & $1.354(7)$ \\
\hline $\mathrm{O} 2 W-\mathrm{Ba} 1-\mathrm{O} 1 W$ & $72.69(14)$ & $\mathrm{O} 1-\mathrm{Ba} 1-\mathrm{O} 3 W$ & $85.63(11)$ \\
\hline $\mathrm{O} 2 W-\mathrm{Ba} 1-\mathrm{O} 4^{\mathrm{i}}$ & $68.74(12)$ & $\mathrm{O}^{\mathrm{ii}}-\mathrm{Ba} 1-\mathrm{O} 3 W$ & 87.04 (11) \\
\hline $\mathrm{O} 1 W-\mathrm{Ba} 1-\mathrm{O} 4^{\mathrm{i}}$ & $83.39(12)$ & $\mathrm{O} 4 W-\mathrm{Ba} 1-\mathrm{O} 3 W$ & 76.65 (11) \\
\hline $\mathrm{O} 2 W-\mathrm{Ba} 1-\mathrm{O} 1$ & $73.66(13)$ & $\mathrm{O} 2 W-\mathrm{B} 1-\mathrm{O} 3 W^{\mathrm{iii}}$ & $124.26(12)$ \\
\hline $\mathrm{O} 1 W-\mathrm{Ba} 1-\mathrm{O} 1$ & $146.32(12)$ & $\mathrm{O} 1 W-\mathrm{Ba} 1-\mathrm{O} 3 W^{\mathrm{iii}}$ & $126.70(12)$ \\
\hline $\mathrm{O} 4^{\mathrm{i}}-\mathrm{Ba} 1-\mathrm{O} 1$ & 85.75 (11) & $\mathrm{O} 4^{\mathrm{i}}-\mathrm{Ba} 1-\mathrm{O} 3 W^{\mathrm{iii}}$ & $64.01(10)$ \\
\hline $\mathrm{O} 2 W-\mathrm{Ba} 1-\mathrm{O}^{\mathrm{ii}}$ & $63.22(12)$ & $\mathrm{O} 1-\mathrm{Ba} 1-\mathrm{O} 3 W^{\mathrm{iii}}$ & $75.02(10)$ \\
\hline $\mathrm{O} 1 W-\mathrm{Ba} 1-\mathrm{O} 5^{\mathrm{ii}}$ & $85.47(12)$ & $\mathrm{O} 5^{\mathrm{ii}}-\mathrm{Ba} 1-\mathrm{O} 3 W^{\mathrm{iii}}$ & $147.67(10)$ \\
\hline $\mathrm{O} 4^{\mathrm{i}}-\mathrm{Ba} 1-\mathrm{O} 5^{\mathrm{ii}}$ & $131.85(10)$ & $\mathrm{O} 4 W-\mathrm{Ba} 1-\mathrm{O} 3 W^{\mathrm{iii}}$ & $60.15(10)$ \\
\hline $\mathrm{O} 1-\mathrm{Ba} 1-\mathrm{O} 5^{\mathrm{ii}}$ & 78.35 (11) & $\mathrm{O} 3 W-\mathrm{Ba} 1-\mathrm{O} 3 W^{\mathrm{iii}}$ & $73.06(5)$ \\
\hline $\mathrm{O} 2 W-\mathrm{Ba} 1-\mathrm{O} 4 W$ & 136.43 (13) & $\mathrm{O} 2 W-\mathrm{Ba} 1-\mathrm{O} 4 W^{\mathrm{iv}}$ & 115.49 (11) \\
\hline $\mathrm{O} 1 W-\mathrm{Ba} 1-\mathrm{O} 4 W$ & $74.19(12)$ & $\mathrm{O} 1 W-\mathrm{Ba} 1-\mathrm{O} 4 W^{\mathrm{iv}}$ & $67.73(11)$ \\
\hline $\mathrm{O} 4^{\mathrm{i}}-\mathrm{Ba} 1-\mathrm{O} 4 W$ & $80.10(11)$ & $\mathrm{O} 4^{\mathrm{i}}-\mathrm{Ba} 1-\mathrm{O} 4 W^{\mathrm{iv}}$ & $146.32(10)$ \\
\hline $\mathrm{O} 1-\mathrm{Ba} 1-\mathrm{O} 4 W$ & $134.80(11)$ & $\mathrm{O} 1-\mathrm{Ba} 1-\mathrm{O} 4 W^{\mathrm{iv}}$ & $127.91(11)$ \\
\hline $\mathrm{O}^{\mathrm{ii}}-\mathrm{Ba} 1-\mathrm{O} 4 W$ & $140.16(11)$ & $\mathrm{O} 5^{\mathrm{ii}}-\mathrm{Ba} 1-\mathrm{O} 4 W^{\mathrm{iv}}$ & $64.82(10)$ \\
\hline $\mathrm{O} 2 W-\mathrm{Ba} 1-\mathrm{O} 3 W$ & $146.29(13)$ & $\mathrm{O} 4 W-\mathrm{Ba} 1-\mathrm{O} 4 W^{\mathrm{iv}}$ & $75.76(7)$ \\
\hline $\mathrm{O} 1 W-\mathrm{Ba} 1-\mathrm{O} 3 W$ & $123.10(12)$ & $\mathrm{O} 3 W-\mathrm{Ba} 1-\mathrm{O} 4 W^{\mathrm{iv}}$ & $58.23(10)$ \\
\hline $\mathrm{O} 4-\mathrm{Ba} 1-\mathrm{O} 3 W$ & 136.99 (11) & $\mathrm{O} 3 W^{\mathrm{iii}}-\mathrm{Ba} 1-\mathrm{O} 4 W^{\mathrm{iv}}$ & $120.18(10)$ \\
\hline
\end{tabular}

Symmetry codes: (i) $-x+\frac{1}{2}, y-\frac{1}{2}, z$; (ii) $-x+\frac{3}{2}, y-\frac{1}{2}, z$; (iii) $x-\frac{1}{2}, y,-z+\frac{1}{2}$; (iv) $x+\frac{1}{2}, y,-z+\frac{1}{2}$.

motif (Table 7). In this respect, the packing of (III) is more similar to the packing of free acid sulfonated azo structures than it is to the packing of equivalent salt forms (Kennedy et al., 2020).

All known $\mathrm{Mg}$ salt forms of sulfonated azo dyes and pigments are solvent-separated ion pairs, with no direct bond between $\mathrm{Mg}$ and $\mathrm{SO}_{3}$ (Kennedy et al., 2006, 2009, 2012). As is shown in Fig. 9, the structure of (IV) is also of this type. Its asymmetric unit contains an $L 2$ anion that is protonated at the azo N1 atom, half of an octahedral $\left[\mathrm{Mg}\left(\mathrm{OH}_{2}\right)\right]_{6}$ dication (with $\mathrm{Mg} 1$ situated at a crystallographic inversion centre) and four noncoordinated water molecules (Table 8). One of the water molecules and the $\mathrm{SO}_{3}$ group ortho to $\mathrm{NH}_{2}$ are disordered. As shown in the packing diagram (Fig. 10), there are hydrophilic layers that extend parallel to the $b c$ plane. The organic anions

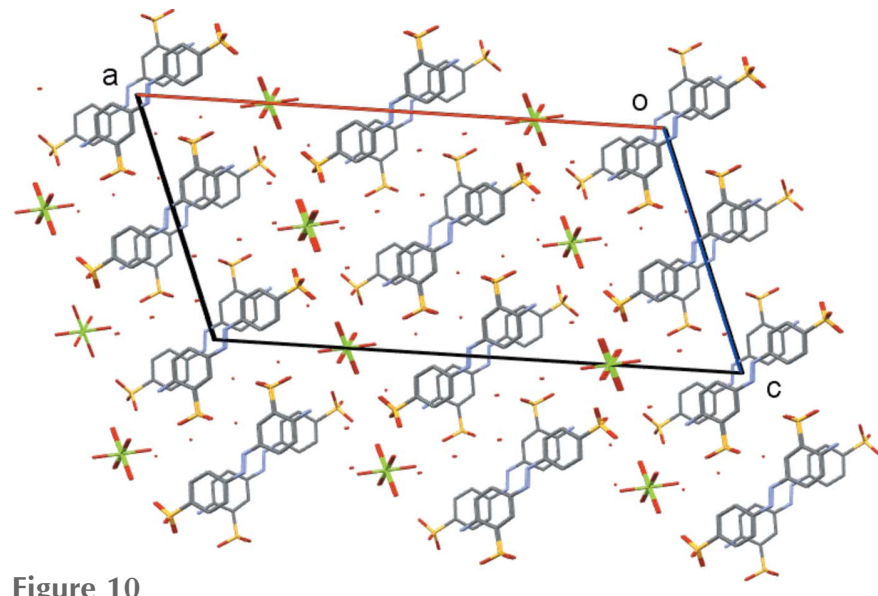

Figure 10

Packing diagram of (IV), viewed down the $b$ axis. $\mathrm{H}$ atoms have been omitted for clarity. Note the solvent water molecules lying within the layers of azo dianions that lie parallel to the $b c$ plane. lie between these but their azobenzene cores do not form continuous hydrophobic layers - instead water molecules are dispersed within these layers. Thus, rather than true twodimensional layers, the hydrophobic azobenzene units form stacks parallel to the $b$ direction surrounded by $\left[\mathrm{Mg}\left(\mathrm{OH}_{2}\right)_{6}\right]^{2+}$ ions and water molecules. As with (III) above, the protonation of the azo unit at the centre of the anion appears to mitigate against the simple alternating layer structures seen elsewhere. In both (III) and (IV), the protonated azo group acts as a hydrogen-bond donor to water molecules (see Tables 7 and 9).

Fig. 11 shows the contents of the asymmetric unit of (V) extended to give the complete coordination geometry (Table 10). The asymmetric unit consists of an azo dianion, a $\mathrm{Ba}^{\mathrm{II}}$ cation with four coordinated water ligands and two nonbound water molecules. The $\mathrm{Ba}$ centre is nonacoordinated, with three bonds to $\mathrm{O}$ atoms of $\mathrm{SO}_{3}$ groups and six bonds to water ligands. The $\mathrm{Ba}-\mathrm{O}-\mathrm{Ba}$ bridges all involve water $\mathrm{O}$ atoms. Both $\mathrm{SO}_{3}$ groups interact with the $\mathrm{Ba}$ atom, with the group ortho to the azo group making two $\mathrm{Ba}-\mathrm{O}$ bonds and the para $\mathrm{SO}_{3}$ group making one bond. This is notable as ortho $\mathrm{SO}_{3}$ groups are generally unfavourable coordination sites compared to para $\mathrm{SO}_{3}$ groups (Kennedy et al., 2009). As with both $L 2$ structures, here the amino group of $L 3$ takes no part in coordination to the metal atom.

Complex (V) forms a two-dimensional coordination polymer. $\mathrm{Ba}-\mathrm{O}-\mathrm{Ba}$ bridges involving the water molecules extend the polymer parallel to the $a$ direction, whilst parallel to the $b$ direction, the polymer propagates through the coordination of the two $\mathrm{SO}_{3}$ groups to give the large $\left[\mathrm{Ba}\left(\mathrm{OH}_{2}\right)_{4}\right.$ $\mathrm{Ba}(L 3)]_{2}$ cyclic structures shown in Fig. 12. The overall packing (Fig. 13) shows a layered structure with hydrophobic and hydrophilic layers parallel to the $a b$ plane. As with (III) and (IV), the amine group of (V) is essentially planar rather than pyramidal. However, it differs by acting as a hydrogenbond donor to only $\mathrm{SO}_{3}$ groups (Table 11), whilst the amine groups of (III) and (IV) donate hydrogen bonds to both $\mathrm{SO}_{3}$ and water groups. None of the amine groups act as hydrogen-

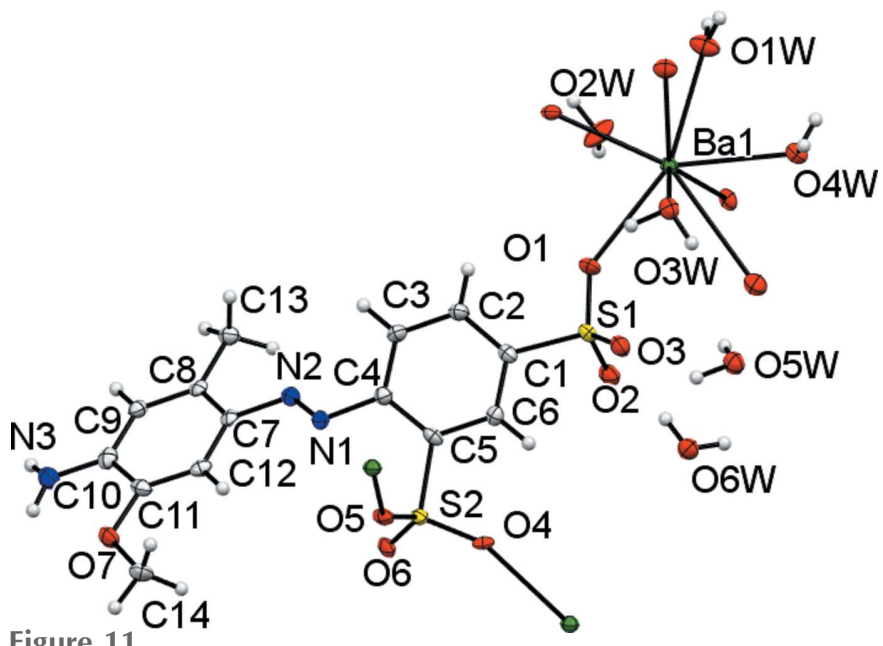

Figure 11

The asymmetric unit of (V) expanded to show the coordination shell about $\mathrm{Ba} 1$ and all dative bonds originating from the modelled dianion. Non-H atoms are shown as $50 \%$ probability displacement ellipsoids and $\mathrm{H}$ atoms are drawn as small spheres of arbitrary size. 


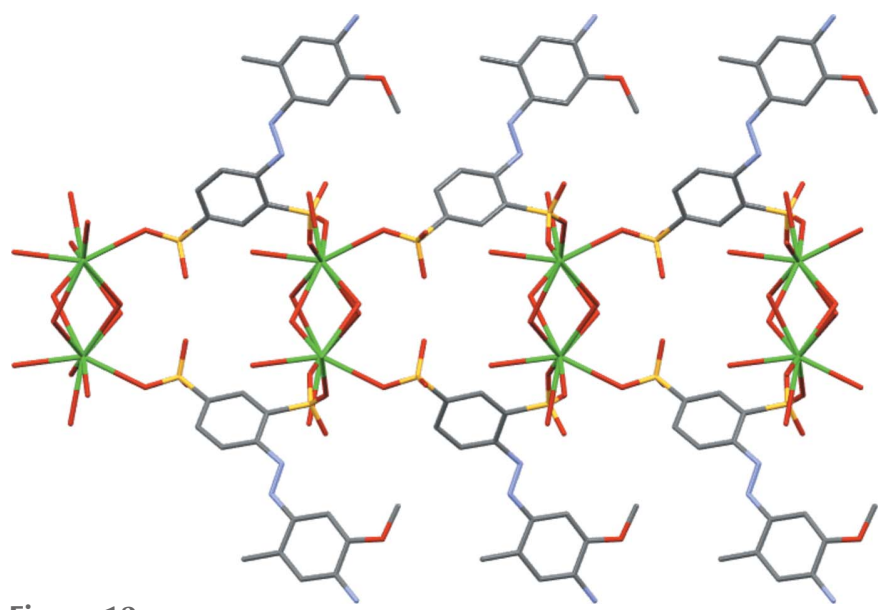

Figure 12

Part of the two-dimensional coordination polymer of (V), viewed down the $a$ axis, showing the coordination polymer extending by $\mathrm{SO}_{3}$ coordination parallel to the $b$ direction.

bond acceptors. Azo atom N1 of (V) does act as a hydrogenbond acceptor from water, as do both azo $\mathrm{N}$ atoms of (I), but this is not the case for any of the other azo $\mathrm{N}$ atoms, see hydrogen-bond tables for details.

The literature on the Ba salt forms of monosulfonated azo dyes predicts structures with no bridging water ligands and with discrete coordination complexes or simple one-dimensional coordination polymers (Kennedy et al., 2004, 2009). Neither prediction is true for disulfonate $(\mathrm{V})$.

For L2, with its protonated azo group, the $\mathrm{N}=\mathrm{N}$ bond lengths of (III) and (IV) are 1.294 (3) and 1.294 (4) respectively. The $\mathrm{N} 2-\mathrm{C} 7$ bond lengths are also equivalent at
Table 11

Hydrogen-bond geometry $\left(\AA,^{\circ}\right)$ for $(\mathrm{V})$.

\begin{tabular}{|c|c|c|c|c|}
\hline$D-\mathrm{H} \cdots A$ & $D-\mathrm{H}$ & $\mathrm{H} \cdots A$ & $D \cdots A$ & $D-\mathrm{H} \cdots A$ \\
\hline $\mathrm{N} 3-\mathrm{H} 1 \mathrm{~N} \cdots \mathrm{O} 2^{\mathrm{v}}$ & $0.88(1)$ & $2.27(2)$ & $3.144(6)$ & $172(6)$ \\
\hline $\mathrm{N} 3-\mathrm{H} 2 \mathrm{~N} \cdots \mathrm{O} 6^{\mathrm{vi}}$ & $0.88(1)$ & $2.28(5)$ & $2.984(6)$ & $138(6)$ \\
\hline $\mathrm{O} 1 W-\mathrm{H} 1 W \cdots \mathrm{O} 2^{\mathrm{i}}$ & $0.87(1)$ & $2.21(3)$ & $2.987(5)$ & $148(5)$ \\
\hline $\mathrm{O} 1 W-\mathrm{H} 2 W \cdots \mathrm{O} 6 W^{\mathrm{vii}}$ & $0.87(1)$ & $1.92(2)$ & $2.766(6)$ & $161(6)$ \\
\hline $\mathrm{O} 2 W-\mathrm{H} 3 W \cdots \mathrm{O} 6^{\mathrm{i}}$ & $0.88(1)$ & $2.03(3)$ & $2.772(6)$ & $141(5)$ \\
\hline $\mathrm{O} 2 W-\mathrm{H} 4 W \cdots \mathrm{N} 1^{\mathrm{ii}}$ & $0.88(1)$ & $2.10(2)$ & $2.948(6)$ & $162(5)$ \\
\hline $\mathrm{O} 3 W-\mathrm{H} 5 W \cdots \mathrm{O} 5 W^{\text {viii }}$ & $0.88(1)$ & $2.04(3)$ & $2.805(5)$ & $145(4)$ \\
\hline $\mathrm{O} 3 W-\mathrm{H} 6 W \cdots \mathrm{O} 5 W^{\text {iv }}$ & $0.88(1)$ & $1.97(1)$ & $2.833(6)$ & $168(5)$ \\
\hline $\mathrm{O} 4 W-\mathrm{H} 7 W \cdots \mathrm{O} 4^{\mathrm{vii}}$ & $0.88(1)$ & $2.06(2)$ & $2.901(5)$ & $160(4)$ \\
\hline $\mathrm{O} 4 W-\mathrm{H} 8 W \cdots \mathrm{O} 6 W^{\mathrm{i}}$ & $0.88(1)$ & $1.87(2)$ & $2.741(5)$ & $171(5)$ \\
\hline $\mathrm{O} 5 W-\mathrm{H} 9 W \cdots \mathrm{O} 2$ & $0.88(1)$ & $1.97(3)$ & $2.805(5)$ & $158(6)$ \\
\hline $\mathrm{O} 5 W-\mathrm{H} 10 W \cdots \mathrm{O} 5^{\mathrm{i}}$ & $0.88(1)$ & $2.17(3)$ & $2.917(5)$ & $143(5)$ \\
\hline $\mathrm{O} 6 W-\mathrm{H} 11 W \cdots \mathrm{O} 3$ & $0.88(1)$ & $1.88(2)$ & $2.737(5)$ & $166(6)$ \\
\hline $\mathrm{O} 6 W-\mathrm{H} 12 W \cdots \mathrm{O} 3^{\mathrm{iii}}$ & $0.88(1)$ & $1.93(1)$ & $2.800(6)$ & $174(5)$ \\
\hline
\end{tabular}

Symmetry codes: (i) $-x+\frac{1}{2}, y-\frac{1}{2}, z$; (ii) $-x+\frac{3}{2}, y-\frac{1}{2}, z$; (iii) $x-\frac{1}{2}, y,-z+\frac{1}{2}$; (iv) $x+\frac{1}{2}, y,-z+\frac{1}{2}$; (v) $-x+1,-y+1,-z$; (vi) $x+\frac{1}{2},-y+\frac{3}{2},-z$; (vii) $-x+1, y-\frac{1}{2}$, $-z+\frac{1}{2}$; (viii) $x+1, y, z$.

1.341 (3) and 1.342 (4) $\AA$. These values are as expected for a protonated azo unit bound to an aniline fragment and, despite being for an anionic ligand, are close matches to those found for the overall neutral but zwitterionic free acid forms of those monosulfonated azo dyes which also feature protonated azo groups (Kennedy et al., 2020). At 1.256 (3) and 1.432 (2) $\AA$, the $\mathrm{N}=\mathrm{N}$ and $\mathrm{N} 2-\mathrm{C} 7$ bond lengths of $L 1$ in (II) are clearly much shorter and longer, respectively, than their equivalents in $L 2$. They fit well with the ranges found for the $4,4^{\prime}$ isomer and with those found for monosulfonated azo species with no strong electron-donating ring substituents (Soegiarto et al., 2009, 2010, 2011; Kennedy et al., 2001, 2020). The $\mathrm{N}=\mathrm{N}$ bond in (I) is 1.262 (4) $\AA$ and is thus outside the ranges of the literature

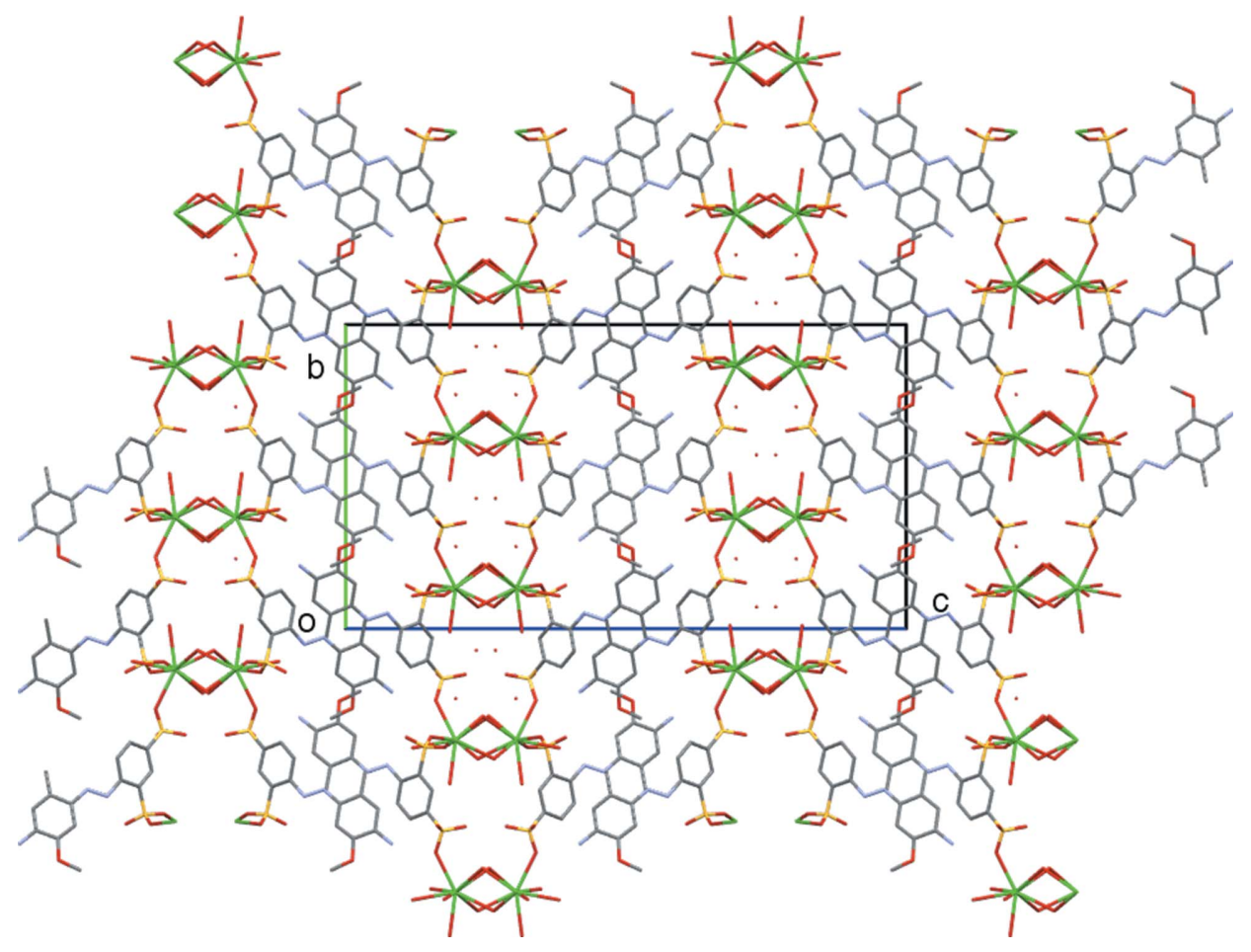

Figure 13

Packing diagram of (V), viewed down the $a$ axis. $\mathrm{H}$ atoms have been omitted for clarity. 
structures above; however, the difference is not statistically significant. For $(\mathrm{V})$, the $\mathrm{N}=\mathrm{N}$ and $\mathrm{N} 2-\mathrm{C} 7$ bond lengths of $L 3$ are intermediate between the lengths reported for $L 1$ and $L 2$ above at 1.277 (6) and 1.393 (6) $\AA$. Such distortions from the expected geometry of azobenzene (Harada \& Ogawa, 2004) can be explained by the resonance electron-donating ability of the $\mathrm{NH}_{2}$ group para to the azo group (Kennedy et al., 2020). The values found for dianion $L 3$ are, however, slightly more distorted from the azobenzene base than has been found for metal complexes of related monoanions, such as 4-aminoazobenzene-4'-sulfonate (Kennedy et al., 2004; Lu et al., 2009). A final point about the geometries of the azo species herein is that in (I)-(IV), the azo moiety is essentially planar [range of dihedral angles between ring planes $\left.=0.00(6)-14.13(6)^{\circ}\right]$. In comparison, the dianion of $(\mathrm{V})$ is distinctly twisted [dihedral angle between the ring planes $\left.=34.0(2)^{\circ}\right]$ and stepped $[e . g$. atom N2 lies 0.905 (9) $\AA$ out of the plane defined by atoms C1-C6].

\section{Conclusion}

Compounds (I) and (II) both contain the simple disulfonate $L 1$ and both have structures that fit with the structural types seen for equivalent monosulfonate salt species - they give the expected dimensionality coordination polymers in which the bonding roles of water ligands are predictable and their packing structures have the expected alternating layer motifs (Kennedy et al., 2004). However, the other three structures presented herein do not have the same structural features as their monosulfonate cognates. Structures (III) and (IV) both contain the monoanion L2. Neither adopts the expected simple alternating layer structure and Na salt (III) is a onedimensional coordination polymer rather than the expected two- or three-dimensional coordination polymer. The strong hydrogen-bonding $\mathrm{N}-\mathrm{H}$ group at the centre of $L 2$ is a feature not seen in other salt structures. This difference gives a rational explanation for the difference in packing behaviour. Finally, the Ba salt of $L 3$, i.e. (V), does give the expected layered packing, but has metal-centre-bridging water ligands and an unexpected two-dimensional rather than a onedimensional coordination polymer structure. The extra dimensionality of the coordination polymer may simply be related to the extra $\mathrm{SO}_{3}$ group in $L 3$ compared to literature structures, but it is less clear why the coordination role of the water ligands should also change.

\section{Acknowledgements}

The authors thank the UK National Crystallography Service (University of Southampton) for the data collection on (V) and Mrs Margaret Adams (University of Strathclyde) for microanalysis. The CCLRC is thanked for providing a beamtime award at Daresbury SRS and Dystar UK are thanked for providing $L 3$ as the free acid form.

\section{References}

Aiken, S., Gabbutt, C. D., Gillie, L. J., Heywood, J. D., Jacquemin, D., Rice, C. R. \& Heron, B. M. (2013). Eur. J. Org. Chem. 2013, 8097-8107.
Altomare, A., Cascarano, G., Giacovazzo, C., Guagliardi, A., Burla, M. C., Polidori, G. \& Camalli, M. (1994). J. Appl. Cryst. 27, 435.

Black, D. T., Kennedy, A. R. \& Lobato, K. M. (2019). Acta Cryst. C75, 633-642.

Bruker (2012). SAINT and SADABS. Bruker AXS Inc., Madison, Wisconsin, USA.

Cernik, R. J., Clegg, W., Catlow, C. R. A., Bushnell-Wye, G., Flaherty, J. V., Greaves, G. N., Burrows, I., Taylor, D. J., Teat, S. J. \& Hamichi, M. (1997). J. Synchrotron Rad. 4, 279-286.

Christie, R. M. \& Mackay, J. L. (2008). Coloration Technol. 124, 133-144.

Coles, S. J. \& Gale, P. A. (2012). Chem. Sci. 3, 683-689.

Farrugia, L. J. (2012). J. Appl. Cryst. 45, 849-854.

Galbraith, H. W., Degering, E. F. \& Hitch, E. F. (1951). J. Am. Chem. Soc. 73, 1323-1324.

Greenwood, D., Hutchings, M. G. \& Lamble, B. (1986). J. Chem. Soc. Perkin Trans. II, pp. 1107-1114.

Harada, J. \& Ogawa, K. (2004). J. Am. Chem. Soc. 126, 3539-3544.

Hooft, R. W. W. (1998). COLLECT. Nonius BV, Delft, The Netherlands.

Hunger, K., Gregory, P., Meiderer, P., Berneth, H., Heid, C. \& Mennicke, W. (2003). Important Chemical Chromophores of Dye Classes, in Industrial Dyes: Chemistry, Properties, Applications, edited by K. Hunge. Weinheim: Wiley-VCH.

Ivashevskaya, S. N., van de Streek, J., Djanhan, J. E., Brüning, J., Alig, E., Bolte, M., Schmidt, M. U., Blaschka, P., Höffken, H. W. \& Erk, P. (2009). Acta Cryst. B65, 212-222.

Kennedy, A. R., Andrikopoulos, P. C., Arlin, J.-B., Armstrong, D. R., Duxbury, N., Graham, D. V. \& Kirkhouse, J. B. A. (2009). Chem. Eur. J. 15, 9494-9504.

Kennedy, A. R., Conway, L. K., Kirkhouse, J. B. A., McCarney, K. M., Puissegur, O., Staunton, E., Teat, S. J. \& Warren, J. E. (2020). Crystals, 10, article No. 662.

Kennedy, A. R., Hughes, M. P., Monaghan, M. L., Staunton, E., Teat, S. J. \& Smith, E. W. (2001). J. Chem. Soc. Dalton Trans. pp. 2199-2205.

Kennedy, A. R., Kirkhouse, J. B. A., McCarney, K. M., Puissegur, O., Smith, W. E., Staunton, E., Teat, S. J., Cherryman, J. C. \& James, R. (2004). Chem. Eur. J. 10, 4606-4615.

Kennedy, A. R., Kirkhouse, J. B. A. \& Whyte, L. (2006). Inorg. Chem. 45, 2965-2971.

Kennedy, A. R., McNair, C., Smith, W. E., Chisholm, G. \& Teat, S. J. (2000). Angew. Chem. Int. Ed. 39, 638-640.

Kennedy, A. R., Stewart, H., Eremin, K. \& Stenger, J. (2012). Chem. Eur. J. 18, 3064-3069.

Lü, J., Gao, S.-Y., Lin, J.-X., Shi, L.-X., Cao, R. \& Batten, S. R. (2009). Dalton Trans. pp. 1944-1953.

Macrae, C. F., Sovago, I., Cottrell, S. J., Galek, P. T. A., McCabe, P., Pidcock, E., Platings, M., Shields, G. P., Stevens, J. S., Towler, M. \& Wood, P. A. (2020). J. Appl. Cryst. 53, 226-235.

Miyano, T., Sakai, T., Hisaki, I., Ichida, H., Kanematsu, Y. \& Tohnai, N. (2016). Chem. Commun. 52, 13710-13713.

Ojala, W. H., Lu, L. K., Albers, K. E., Gleason, W. B., Richardson, T. I., Lovrien, R. E. \& Sudbeck, E. A. (1994). Acta Cryst. B50, 684-694.

Otwinowski, Z. \& Minor, W. (1997). Methods in Enzymology, Vol. 276, Macromolecular Crystallography, Part A, edited by C. W. Carter Jr \& R. M. Sweet, pp. 307-326. New York: Academic Press.

Rigaku OD (2019). CrysAlis PRO. Rigaku Oxford Diffraction Ltd, Yarnton, Oxfordshire, England.

Schmidt, M. U., van de Streek, J. \& Ivashevskaya, S. N. (2009). Chem. Eur. J. 15, 338-341.

Sheldrick, G. M. (2015). Acta Cryst. C71, 3-8.

Soegiarto, A. C., Comotti, A. \& Ward, M. D. (2010). J. Am. Chem. Soc. 132, 14603-14616.

Soegiarto, A. C. \& Ward, M. D. (2009). Cryst. Growth Des. 9, $3803-$ 3815.

Soegiarto, A. C., Yan, W., Kent, A. D. \& Ward, M. D. (2011). J. Mater. Chem. 21, 2204-2219.

Tapmeyer, L., Hill, S., Bolte, M. \& Hützler, W. M. (2020). Acta Cryst. C76, 716-722. 


\section{supporting information}

Acta Cryst. (2020). C76, 972-981 [https://doi.org/10.1107/S2053229620012735]

Structures of five salt forms of disulfonated monoazo dyes

Heather C. Gardner, Alan R. Kennedy, Karen M. McCarney, Edward Staunton, Heather

Stewart and Simon J. Teat

Computing details

Data collection: DENZO (Otwinowski \& Minor, 1997) and COLLECT (Hooft, 1998) for (I), (II), (V); SAINT (Bruker, 2012) for (III); CrysAlis PRO (Rigaku OD, 2019) for (IV). Cell refinement: DENZO (Otwinowski \& Minor, 1997) for (I), (II), (V); SAINT (Bruker, 2012) for (III); CrysAlis PRO (Rigaku OD, 2019) for (IV). Data reduction: DENZO (Otwinowski \& Minor, 1997) for (I), (II), (V); SAINT (Bruker, 2012) for (III); CrysAlis PRO (Rigaku OD, 2019) for (IV). Program(s) used to solve structure: SHELXS (Sheldrick, 2015) for (I), (III); SIR92 (Altomare et al., 1994) for (II), (IV), (V). For all structures, program(s) used to refine structure: SHELXL2014 (Sheldrick, 2015) and WinGX (Farrugia, 2012); molecular graphics: Mercury (Macrae et al., 2020) and ORTEP-3 (Farrugia, 2012). Software used to prepare material for publication: SHELXL2014 (Sheldrick, 2015) for (I), (II), (IV), (V).

Poly[di- $\mu$-aqua-diaqua $\left[\mu_{4}-3,3\right.$ '-(diazane-1,2-diyl)bis(benzenesulfonato)]disodium(I)] (I)

Crystal data

$\left[\mathrm{Na}_{2}\left(\mathrm{C}_{12} \mathrm{H}_{8} \mathrm{~N}_{2} \mathrm{O}_{6} \mathrm{~S}_{2}\right)\left(\mathrm{H}_{2} \mathrm{O}\right)_{4}\right]$

$M_{r}=458.37$

Monoclinic, $C 2 / c$

$a=21.2141(9) \AA$

$b=5.5370(3) \AA$

$c=15.3045(8) \AA$

$\beta=90.310(2)^{\circ}$

$V=1797.68(16) \AA^{3}$

$Z=4$

Data collection

Nonius KappaCCD diffractometer

Radiation source: sealed tube $\omega$ and phi scans 3500 measured reflections 1865 independent reflections

Refinement

Refinement on $F^{2}$

Least-squares matrix: full

$R\left[F^{2}>2 \sigma\left(F^{2}\right)\right]=0.038$

$w R\left(F^{2}\right)=0.090$

$S=1.04$

1865 reflections
$F(000)=944$

$D_{\mathrm{x}}=1.694 \mathrm{Mg} \mathrm{m}^{-3}$

Mo $K \alpha$ radiation, $\lambda=0.71073 \AA$

Cell parameters from 2025 reflections

$\theta=1.0-26.4^{\circ}$

$\mu=0.40 \mathrm{~mm}^{-1}$

$T=130 \mathrm{~K}$

Plate, yellow

$0.50 \times 0.32 \times 0.08 \mathrm{~mm}$

1414 reflections with $I>2 \sigma(I)$

$R_{\text {int }}=0.035$

$\theta_{\text {max }}=26.6^{\circ}, \theta_{\min }=1.9^{\circ}$

$h=0 \rightarrow 26$

$k=-6 \rightarrow 6$

$l=-19 \rightarrow 19$

145 parameters

6 restraints

Hydrogen site location: mixed

$\mathrm{H}$ atoms treated by a mixture of independent and constrained refinement 
$w=1 /\left[\sigma^{2}\left(F_{\mathrm{o}}^{2}\right)+(0.0342 P)^{2}+3.0179 P\right]$

where $P=\left(F_{\mathrm{o}}^{2}+2 F_{\mathrm{c}}^{2}\right) / 3$

$(\Delta / \sigma)_{\max }<0.001$

$$
\Delta \rho_{\max }=0.43 \text { e } \AA^{-3}
$$

\section{Special details}

Geometry. All esds (except the esd in the dihedral angle between two 1.s. planes) are estimated using the full covariance matrix. The cell esds are taken into account individually in the estimation of esds in distances, angles and torsion angles; correlations between esds in cell parameters are only used when they are defined by crystal symmetry. An approximate (isotropic) treatment of cell esds is used for estimating esds involving l.s. planes.

Fractional atomic coordinates and isotropic or equivalent isotropic displacement parameters $\left(\AA^{2}\right)$

\begin{tabular}{lllll}
\hline & $x$ & $y$ & $z$ & $U_{\text {iso }} * U_{\text {eq }}$ \\
\hline S1 & $0.09144(3)$ & $0.74864(11)$ & $0.31076(4)$ & $0.01712(16)$ \\
Na1 & 0.0000 & $0.2759(2)$ & 0.2500 & $0.0219(3)$ \\
Na2 & 0.0000 & 0.5000 & 0.5000 & $0.0195(3)$ \\
O1 & $0.08204(8)$ & $0.5777(3)$ & $0.23944(11)$ & $0.0253(4)$ \\
O2 & $0.05412(8)$ & $0.6889(4)$ & $0.38656(11)$ & $0.0351(5)$ \\
O3 & $0.08455(8)$ & $0.9976(3)$ & $0.28351(12)$ & $0.0293(4)$ \\
O1W & $-0.01637(9)$ & $0.1643(3)$ & $0.40666(11)$ & $0.0237(4)$ \\
O2W & $-0.08853(8)$ & $0.7231(3)$ & $0.43599(11)$ & $0.0256(4)$ \\
N1 & $0.27167(9)$ & $0.3035(3)$ & $0.47962(12)$ & $0.0186(4)$ \\
C1 & $0.17132(11)$ & $0.7150(4)$ & $0.34449(14)$ & $0.0157(5)$ \\
C2 & $0.18751(11)$ & $0.5193(4)$ & $0.39621(15)$ & $0.0180(5)$ \\
H2 & 0.1567 & 0.4030 & 0.4121 & $0.022^{*}$ \\
C3 & $0.24990(11)$ & $0.4954(4)$ & $0.42461(14)$ & $0.0182(5)$ \\
C4 & $0.29542(11)$ & $0.6610(4)$ & $0.39847(15)$ & $0.0196(5)$ \\
H4 & 0.3380 & 0.6416 & 0.4168 & $0.023^{*}$ \\
C5 & $0.27865(11)$ & $0.8541(5)$ & $0.34576(15)$ & $0.0205(5)$ \\
H5 & 0.3098 & 0.9664 & 0.3275 & $0.025^{*}$ \\
C6 & $0.21610(11)$ & $0.8837(4)$ & $0.31940(15)$ & $0.0182(5)$ \\
H6 & 0.2042 & 1.0183 & 0.2845 & $0.022^{*}$ \\
H1W & $0.0172(9)$ & $0.076(5)$ & $0.399(2)$ & $0.066(12)^{*}$ \\
H2W & $-0.0447(11)$ & $0.052(5)$ & $0.415(2)$ & $0.076(13)^{*}$ \\
H3W & $-0.0888(13)$ & $0.676(6)$ & $0.3820(9)$ & $0.053(11)^{*}$ \\
H4W & $-0.1281(6)$ & $0.723(6)$ & $0.4498(18)$ & $0.053(10)^{*}$ \\
& & & &
\end{tabular}

Atomic displacement parameters $\left(\AA^{2}\right)$

\begin{tabular}{lllllll}
\hline & $U^{11}$ & $U^{22}$ & $U^{33}$ & $U^{12}$ & $U^{13}$ & $U^{23}$ \\
\hline $\mathrm{S} 1$ & $0.0161(3)$ & $0.0178(3)$ & $0.0175(3)$ & $0.0025(3)$ & $0.0005(2)$ & $0.0031(3)$ \\
$\mathrm{Na} 1$ & $0.0230(7)$ & $0.0185(7)$ & $0.0242(7)$ & 0.000 & $0.0003(5)$ & 0.000 \\
$\mathrm{Na} 2$ & $0.0220(7)$ & $0.0179(7)$ & $0.0185(7)$ & $0.0000(6)$ & $0.0002(5)$ & $0.0003(6)$ \\
$\mathrm{O} 1$ & $0.0213(9)$ & $0.0257(10)$ & $0.0291(10)$ & $0.0017(8)$ & $-0.0031(7)$ & $-0.0061(8)$ \\
$\mathrm{O} 2$ & $0.0229(10)$ & $0.0565(14)$ & $0.0259(10)$ & $0.0079(9)$ & $0.0063(8)$ & $0.0157(9)$ \\
O3 & $0.0258(10)$ & $0.0193(9)$ & $0.0425(11)$ & $0.0045(8)$ & $-0.0077(8)$ & $0.0058(8)$ \\
O1W & $0.0255(10)$ & $0.0207(9)$ & $0.0250(10)$ & $0.0017(8)$ & $0.0000(8)$ & $-0.0023(8)$ \\
O2W & $0.0201(10)$ & $0.0336(11)$ & $0.0230(10)$ & $0.0017(8)$ & $-0.0005(7)$ & $0.0021(9)$ \\
N1 & $0.0194(10)$ & $0.0184(11)$ & $0.0181(10)$ & $0.0028(8)$ & $-0.0014(8)$ & $-0.0002(8)$
\end{tabular}


supporting information

\begin{tabular}{lllllll} 
C1 & $0.0161(11)$ & $0.0174(12)$ & $0.0135(11)$ & $0.0023(10)$ & $0.0009(9)$ & $-0.0020(9)$ \\
C2 & $0.0189(13)$ & $0.0157(12)$ & $0.0194(12)$ & $0.0003(10)$ & $0.0022(9)$ & $0.0015(10)$ \\
C3 & $0.0225(13)$ & $0.0166(12)$ & $0.0155(11)$ & $0.0024(10)$ & $-0.0010(9)$ & $-0.0001(10)$ \\
C4 & $0.0170(12)$ & $0.0230(13)$ & $0.0188(12)$ & $0.0011(10)$ & $-0.0013(9)$ & $-0.0031(10)$ \\
C5 & $0.0215(13)$ & $0.0201(12)$ & $0.0200(12)$ & $-0.0053(10)$ & $0.0015(10)$ & $-0.0012(11)$ \\
C6 & $0.0245(13)$ & $0.0152(12)$ & $0.0149(11)$ & $0.0003(10)$ & $0.0002(9)$ & $0.0006(10)$ \\
\hline
\end{tabular}

Geometric parameters $\left(\AA,{ }^{\circ}\right)$

\begin{tabular}{|c|c|c|c|}
\hline $\mathrm{S} 1-\mathrm{O} 2$ & $1.4464(18)$ & $\mathrm{Na} 2-\mathrm{O} 2 \mathrm{~W}$ & $2.4480(17)$ \\
\hline $\mathrm{S} 1-\mathrm{O} 3$ & $1.4474(18)$ & $\mathrm{Na} 2-\mathrm{Na} 1^{\mathrm{iv}}$ & $4.0223(4)$ \\
\hline $\mathrm{S} 1-\mathrm{O} 1$ & $1.4575(18)$ & $\mathrm{O} 3-\mathrm{Na}^{\mathrm{v}}$ & $2.4174(19)$ \\
\hline $\mathrm{S} 1-\mathrm{C} 1$ & $1.779(2)$ & $\mathrm{O} 1 \mathrm{~W}-\mathrm{H} 1 \mathrm{~W}$ & $0.871(10)$ \\
\hline $\mathrm{S} 1-\mathrm{Na} 1$ & $3.3852(12)$ & $\mathrm{O} 1 \mathrm{~W}-\mathrm{H} 2 \mathrm{~W}$ & $0.872(10)$ \\
\hline $\mathrm{Na} 1-\mathrm{O} 3^{\mathrm{i}}$ & $2.4174(19)$ & $\mathrm{O} 2 \mathrm{~W}-\mathrm{H} 3 \mathrm{~W}$ & $0.867(10)$ \\
\hline $\mathrm{Na} 1-\mathrm{O}^{\mathrm{ii}}$ & $2.4175(19)$ & $\mathrm{O} 2 \mathrm{~W}-\mathrm{H} 4 \mathrm{~W}$ & $0.866(10)$ \\
\hline $\mathrm{Na} 1-\mathrm{O} 1$ & $2.419(2)$ & $\mathrm{N} 1-\mathrm{N} 1^{\mathrm{vi}}$ & $1.262(4)$ \\
\hline $\mathrm{Na} 1-\mathrm{O} 1^{\mathrm{iii}}$ & $2.419(2)$ & $\mathrm{N} 1-\mathrm{C} 3$ & $1.431(3)$ \\
\hline $\mathrm{Na} 1-\mathrm{O} 1 \mathrm{~W}^{\mathrm{iii}}$ & $2.5019(18)$ & $\mathrm{C} 1-\mathrm{C} 2$ & $1.384(3)$ \\
\hline $\mathrm{Na} 1-\mathrm{O} 1 \mathrm{~W}$ & $2.5019(18)$ & $\mathrm{C} 1-\mathrm{C} 6$ & $1.388(3)$ \\
\hline $\mathrm{Na} 1-\mathrm{S} 1^{\mathrm{iii}}$ & $3.3853(12)$ & $\mathrm{C} 2-\mathrm{C} 3$ & $1.397(3)$ \\
\hline $\mathrm{Na} 1-\mathrm{Na} 2$ & $4.0223(5)$ & $\mathrm{C} 2-\mathrm{H} 2$ & 0.9500 \\
\hline $\mathrm{Na} 1-\mathrm{Na} 2^{\mathrm{iii}}$ & $4.0223(5)$ & $\mathrm{C} 3-\mathrm{C} 4$ & $1.392(3)$ \\
\hline $\mathrm{Na} 1-\mathrm{H} 1 \mathrm{~W}$ & $2.56(3)$ & $\mathrm{C} 4-\mathrm{C} 5$ & $1.384(3)$ \\
\hline $\mathrm{Na} 2-\mathrm{O} 2^{\mathrm{iv}}$ & $2.3340(18)$ & $\mathrm{C} 4-\mathrm{H} 4$ & 0.9500 \\
\hline $\mathrm{Na} 2-\mathrm{O} 2$ & $2.3340(18)$ & $\mathrm{C} 5-\mathrm{C} 6$ & $1.395(3)$ \\
\hline $\mathrm{Na} 2-\mathrm{O} 1 \mathrm{~W}$ & $2.3688(17)$ & $\mathrm{C} 5-\mathrm{H} 5$ & 0.9500 \\
\hline $\mathrm{Na} 2-\mathrm{O}_{1} \mathrm{~W}^{\mathrm{iv}}$ & $2.3688(17)$ & $\mathrm{C} 6-\mathrm{H} 6$ & 0.9500 \\
\hline $\mathrm{Na} 2-\mathrm{O} 2 \mathrm{~W}^{\mathrm{iv}}$ & $2.4480(17)$ & & \\
\hline $\mathrm{O} 2-\mathrm{S} 1-\mathrm{O} 3$ & $113.21(12)$ & $\mathrm{S} 1 \mathrm{iii}-\mathrm{Na} 1-\mathrm{H} 1 \mathrm{~W}$ & $131.1(4)$ \\
\hline $\mathrm{O} 2-\mathrm{S} 1-\mathrm{O} 1$ & $112.26(12)$ & $\mathrm{Na} 2-\mathrm{Na} 1-\mathrm{H} 1 \mathrm{~W}$ & $44.4(6)$ \\
\hline $\mathrm{O} 3-\mathrm{S} 1-\mathrm{O} 1$ & $112.92(11)$ & $\mathrm{Na} 2^{\mathrm{iii}}-\mathrm{Na} 1-\mathrm{H} 1 \mathrm{~W}$ & $168.6(3)$ \\
\hline $\mathrm{O} 2-\mathrm{S} 1-\mathrm{C} 1$ & $105.55(10)$ & $\mathrm{O} 2{ }^{\mathrm{iv}}-\mathrm{Na} 2-\mathrm{O} 2$ & 180.0 \\
\hline $\mathrm{O} 3-\mathrm{S} 1-\mathrm{C} 1$ & $106.13(11)$ & $\mathrm{O} 2^{\mathrm{iv}}-\mathrm{Na} 2-\mathrm{O} 1 \mathrm{~W}$ & $91.49(7)$ \\
\hline $\mathrm{O} 1-\mathrm{S} 1-\mathrm{C} 1$ & $106.00(10)$ & $\mathrm{O} 2-\mathrm{Na} 2-\mathrm{O} 1 \mathrm{~W}$ & $88.51(7)$ \\
\hline $\mathrm{O} 2-\mathrm{S} 1-\mathrm{Na} 1$ & $74.22(9)$ & $\mathrm{O} 2^{\mathrm{iv}}-\mathrm{Na} 2-\mathrm{O} 1 \mathrm{~W}^{\mathrm{iv}}$ & $88.51(7)$ \\
\hline $\mathrm{O} 3-\mathrm{S} 1-\mathrm{Na} 1$ & $126.91(8)$ & $\mathrm{O} 2-\mathrm{Na} 2-\mathrm{O} 1 \mathrm{~W}^{\mathrm{iv}}$ & $91.49(7)$ \\
\hline $\mathrm{O} 1-\mathrm{S} 1-\mathrm{Na} 1$ & $38.41(7)$ & $\mathrm{O} 1 \mathrm{~W}-\mathrm{Na} 2-\mathrm{O} 1 \mathrm{~W}^{\mathrm{iv}}$ & 180.0 \\
\hline $\mathrm{C} 1-\mathrm{S} 1-\mathrm{Na} 1$ & $122.85(8)$ & $\mathrm{O} 2^{\mathrm{iv}}-\mathrm{Na} 2-\mathrm{O} 2 \mathrm{~W}^{\mathrm{iv}}$ & $81.69(6)$ \\
\hline $\mathrm{O}^{\mathrm{i}}-\mathrm{Na} 1-\mathrm{O}^{\mathrm{ii}}$ & $100.81(10)$ & $\mathrm{O} 2-\mathrm{Na} 2-\mathrm{O} 2 \mathrm{~W}^{\mathrm{iv}}$ & $98.30(6)$ \\
\hline 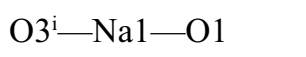 & $85.49(6)$ & $\mathrm{O} 1 \mathrm{~W}-\mathrm{Na} 2-\mathrm{O} 2 \mathrm{~W}^{\mathrm{iv}}$ & $87.42(6)$ \\
\hline 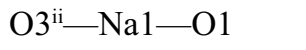 & $163.62(6)$ & $\mathrm{O} 1 \mathrm{~W}^{\mathrm{iv}}-\mathrm{Na} 2-\mathrm{O} 2 \mathrm{~W}^{\mathrm{iv}}$ & $92.58(6)$ \\
\hline $\mathrm{O} 3^{\mathrm{i}}-\mathrm{Na} 1-\mathrm{O} 1^{\mathrm{iii}}$ & $163.62(6)$ & $\mathrm{O} 2^{\mathrm{iv}}-\mathrm{Na} 2-\mathrm{O} 2 \mathrm{~W}$ & $98.31(6)$ \\
\hline $\mathrm{O} 3^{\mathrm{ii}}-\mathrm{Na} 1-\mathrm{O} 1^{\mathrm{iii}}$ & $85.49(6)$ & $\mathrm{O} 2-\mathrm{Na} 2-\mathrm{O} 2 \mathrm{~W}$ & $81.70(6)$ \\
\hline $\mathrm{O} 1-\mathrm{Na} 1-\mathrm{O} 1^{\mathrm{iii}}$ & $92.59(9)$ & $\mathrm{O} 1 \mathrm{~W}-\mathrm{Na} 2-\mathrm{O} 2 \mathrm{~W}$ & $92.58(6)$ \\
\hline 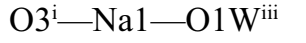 & $86.52(7)$ & $\mathrm{O}_{1} \mathrm{~W}^{\mathrm{iv}}-\mathrm{Na} 2-\mathrm{O} 2 \mathrm{~W}$ & $87.42(6)$ \\
\hline $\mathrm{O} 3^{\mathrm{ii}}-\mathrm{Na} 1-\mathrm{O} 1 \mathrm{~W}^{\mathrm{iii}}$ & $75.28(6)$ & $\mathrm{O} 2 \mathrm{~W}^{\mathrm{iv}}-\mathrm{Na} 2-\mathrm{O} 2 \mathrm{~W}$ & 180.0 \\
\hline
\end{tabular}




\begin{tabular}{|c|c|c|c|}
\hline $\mathrm{O} 1-\mathrm{Na} 1-\mathrm{O} 1 \mathrm{~W}^{\mathrm{iii}}$ & $90.17(6)$ & $\mathrm{O} 2^{\mathrm{iv}}-\mathrm{Na} 2-\mathrm{Na} 1$ & $124.88(5)$ \\
\hline $\mathrm{O} 1^{\mathrm{iii}}-\mathrm{Na} 1-\mathrm{O} 1 \mathrm{~W}^{\mathrm{iii}}$ & $109.77(6)$ & $\mathrm{O} 2-\mathrm{Na} 2-\mathrm{Na} 1$ & $55.12(5)$ \\
\hline $\mathrm{O} 3^{\mathrm{i}}-\mathrm{Na} 1-\mathrm{O} 1 \mathrm{~W}$ & $75.28(6)$ & $\mathrm{O} 1 \mathrm{~W}-\mathrm{Na} 2-\mathrm{Na} 1$ & $35.41(5)$ \\
\hline 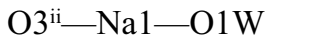 & $86.52(7)$ & $\mathrm{O}_{1} \mathrm{~W}^{\mathrm{iv}}-\mathrm{Na} 2-\mathrm{Na} 1$ & $144.59(5)$ \\
\hline $\mathrm{O} 1-\mathrm{Na} 1-\mathrm{O} 1 \mathrm{~W}$ & $109.77(6)$ & $\mathrm{O} 2 \mathrm{~W}^{\mathrm{iv}}-\mathrm{Na} 2-\mathrm{Na} 1$ & $102.77(4)$ \\
\hline $\mathrm{O} 1{ }^{\mathrm{iii}}-\mathrm{Na} 1-\mathrm{O} 1 \mathrm{~W}$ & $90.17(6)$ & $\mathrm{O} 2 \mathrm{~W}-\mathrm{Na} 2-\mathrm{Na} 1$ & $77.23(4)$ \\
\hline $\mathrm{O} 1 \mathrm{~W}$ iii-Na1-O1W & $151.40(10)$ & $\mathrm{O} 2^{\mathrm{iv}}-\mathrm{Na} 2-\mathrm{Na} 1^{\mathrm{iv}}$ & $55.12(5)$ \\
\hline 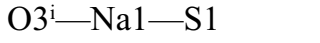 & $90.64(4)$ & $\mathrm{O} 2-\mathrm{Na} 2-\mathrm{Na} 1^{\mathrm{iv}}$ & $124.88(5)$ \\
\hline $\mathrm{O} 3^{\mathrm{ii}}-\mathrm{Na} 1-\mathrm{S} 1$ & $167.03(6)$ & $\mathrm{O} 1 \mathrm{~W}-\mathrm{Na} 2-\mathrm{Na} 1^{\mathrm{iv}}$ & $144.59(5)$ \\
\hline $\mathrm{O} 1-\mathrm{Na} 1-\mathrm{S} 1$ & $21.98(4)$ & $\mathrm{O} 1 \mathrm{~W}^{\mathrm{iv}}-\mathrm{Na} 2-\mathrm{Na} 1^{\mathrm{iv}}$ & $35.41(5)$ \\
\hline $\mathrm{O} 1{ }^{\mathrm{iii}}-\mathrm{Na} 1-\mathrm{S} 1$ & $81.88(5)$ & $\mathrm{O} 2 \mathrm{~W}^{\mathrm{iv}}-\mathrm{Na} 2-\mathrm{Na} 1^{\mathrm{iv}}$ & $77.23(4)$ \\
\hline $\mathrm{O} 1 \mathrm{~W}^{\mathrm{iii}}-\mathrm{Na} 1-\mathrm{S} 1$ & $111.83(5)$ & $\mathrm{O} 2 \mathrm{~W}-\mathrm{Na} 2-\mathrm{Na} 1^{\mathrm{iv}}$ & $102.77(4)$ \\
\hline $\mathrm{O} 1 \mathrm{~W}-\mathrm{Na} 1-\mathrm{S} 1$ & $90.57(5)$ & $\mathrm{Na} 1-\mathrm{Na} 2-\mathrm{Na} 1^{\mathrm{iv}}$ & 180.0 \\
\hline 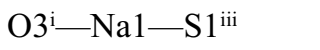 & $167.03(6)$ & $\mathrm{S} 1-\mathrm{O} 1-\mathrm{Na} 1$ & $119.61(10)$ \\
\hline $\mathrm{O} 3^{\mathrm{ii}}-\mathrm{Na} 1-\mathrm{S} 1^{\mathrm{iii}}$ & $90.64(4)$ & $\mathrm{S} 1-\mathrm{O} 2-\mathrm{Na} 2$ & $166.59(14)$ \\
\hline $\mathrm{O} 1-\mathrm{Na} 1-\mathrm{S} 1^{\mathrm{iii}}$ & $81.88(5)$ & $\mathrm{S} 1-\mathrm{O} 3-\mathrm{Na} 1^{\mathrm{v}}$ & $137.88(11)$ \\
\hline 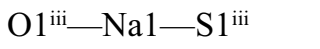 & $21.98(4)$ & $\mathrm{Na} 2-\mathrm{O} 1 \mathrm{~W}-\mathrm{Na} 1$ & $111.31(8)$ \\
\hline $\mathrm{O} 1 \mathrm{~W}^{\mathrm{iii}}-\mathrm{Na} 1-\mathrm{S} 1^{\mathrm{iii}}$ & $90.58(5)$ & $\mathrm{Na} 2-\mathrm{O} 1 \mathrm{~W}-\mathrm{H} 1 \mathrm{~W}$ & $114(2)$ \\
\hline $\mathrm{O} 1 \mathrm{~W}-\mathrm{Na} 1-\mathrm{S} 1^{\mathrm{iii}}$ & $111.83(5)$ & $\mathrm{Na} 1-\mathrm{O} 1 \mathrm{~W}-\mathrm{H} 1 \mathrm{~W}$ & $84(2)$ \\
\hline $\mathrm{S} 1-\mathrm{Na} 1-\mathrm{S} 1^{\mathrm{iii}}$ & $78.70(3)$ & $\mathrm{Na} 2-\mathrm{O} 1 \mathrm{~W}-\mathrm{H} 2 \mathrm{~W}$ & $125(2)$ \\
\hline $\mathrm{O} 3{ }^{\mathrm{i}}-\mathrm{Na} 1-\mathrm{Na} 2$ & $89.92(4)$ & $\mathrm{Na} 1-\mathrm{O} 1 \mathrm{~W}-\mathrm{H} 2 \mathrm{~W}$ & $114(3)$ \\
\hline $\mathrm{O} 3{ }^{\mathrm{ii}}-\mathrm{Na} 1-\mathrm{Na} 2$ & $113.24(5)$ & $\mathrm{H} 1 \mathrm{~W}-\mathrm{O} 1 \mathrm{~W}-\mathrm{H} 2 \mathrm{~W}$ & $101(2)$ \\
\hline $\mathrm{O} 1-\mathrm{Na} 1-\mathrm{Na} 2$ & $81.61(4)$ & $\mathrm{Na} 2-\mathrm{O} 2 \mathrm{~W}-\mathrm{H} 3 \mathrm{~W}$ & $103(2)$ \\
\hline $\mathrm{O} 1^{1 \mathrm{ii}-\mathrm{Na} 1-\mathrm{Na} 2}$ & $73.71(4)$ & $\mathrm{Na} 2-\mathrm{O} 2 \mathrm{~W}-\mathrm{H} 4 \mathrm{~W}$ & $130(2)$ \\
\hline $\mathrm{O} 1 \mathrm{~W}^{\mathrm{iii}}-\mathrm{Na} 1-\mathrm{Na} 2$ & $171.28(5)$ & $\mathrm{H} 3 \mathrm{~W}-\mathrm{O} 2 \mathrm{~W}-\mathrm{H} 4 \mathrm{~W}$ & $103.3(19)$ \\
\hline $\mathrm{O} 1 \mathrm{~W}-\mathrm{Na} 1-\mathrm{Na} 2$ & $33.27(4)$ & $\mathrm{N} 1^{\mathrm{vi}-\mathrm{N} 1-\mathrm{C} 3}$ & $113.9(2)$ \\
\hline $\mathrm{S} 1-\mathrm{Na} 1-\mathrm{Na} 2$ & $60.206(15)$ & $\mathrm{C} 2-\mathrm{C} 1-\mathrm{C} 6$ & $121.1(2)$ \\
\hline $\mathrm{S} 1{ }^{\mathrm{iii}}-\mathrm{Na} 1-\mathrm{Na} 2$ & $91.13(2)$ & $\mathrm{C} 2-\mathrm{C} 1-\mathrm{S} 1$ & $118.74(18)$ \\
\hline $\mathrm{O} 3^{\mathrm{i}}-\mathrm{Na} 1-\mathrm{Na} 2^{\mathrm{iii}}$ & $113.24(5)$ & $\mathrm{C} 6-\mathrm{C} 1-\mathrm{S} 1$ & $120.12(17)$ \\
\hline $\mathrm{O} 3^{\mathrm{ii}}-\mathrm{Na} 1-\mathrm{Na} 2^{\mathrm{iii}}$ & $89.92(4)$ & $\mathrm{C} 1-\mathrm{C} 2-\mathrm{C} 3$ & $118.9(2)$ \\
\hline $\mathrm{O} 1-\mathrm{Na} 1-\mathrm{Na} 2^{\mathrm{iii}}$ & $73.71(4)$ & $\mathrm{C} 1-\mathrm{C} 2-\mathrm{H} 2$ & 120.5 \\
\hline $\mathrm{O} 1^{\mathrm{iii}}-\mathrm{Na} 1-\mathrm{Na} 2^{\mathrm{iii}}$ & $81.61(4)$ & $\mathrm{C} 3-\mathrm{C} 2-\mathrm{H} 2$ & 120.5 \\
\hline $\mathrm{O} 1 \mathrm{~W}^{\mathrm{iii}}-\mathrm{Na} 1-\mathrm{Na} 2^{\mathrm{iii}}$ & $33.27(4)$ & $\mathrm{C} 4-\mathrm{C} 3-\mathrm{C} 2$ & $120.4(2)$ \\
\hline $\mathrm{O} 1 \mathrm{~W}-\mathrm{Na} 1-\mathrm{Na} 2^{\mathrm{iii}}$ & $171.28(5)$ & $\mathrm{C} 4-\mathrm{C} 3-\mathrm{N} 1$ & $115.9(2)$ \\
\hline $\mathrm{S} 1-\mathrm{Na} 1-\mathrm{Na} 2^{\mathrm{iii}}$ & $91.13(2)$ & $\mathrm{C} 2-\mathrm{C} 3-\mathrm{N} 1$ & $123.7(2)$ \\
\hline $\mathrm{S} 1^{\mathrm{iii}}-\mathrm{Na} 1-\mathrm{Na} 2^{\mathrm{iii}}$ & $60.207(15)$ & $\mathrm{C} 5-\mathrm{C} 4-\mathrm{C} 3$ & $120.0(2)$ \\
\hline $\mathrm{Na} 2-\mathrm{Na} 1-\mathrm{Na} 2^{\mathrm{iii}}$ & $144.06(4)$ & $\mathrm{C} 5-\mathrm{C} 4-\mathrm{H} 4$ & 120.0 \\
\hline 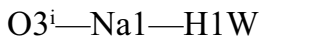 & $55.5(3)$ & $\mathrm{C} 3-\mathrm{C} 4-\mathrm{H} 4$ & 120.0 \\
\hline $\mathrm{O} 3^{\mathrm{ii}}-\mathrm{Na} 1-\mathrm{H} 1 \mathrm{~W}$ & $90.9(7)$ & $\mathrm{C} 4-\mathrm{C} 5-\mathrm{C} 6$ & $120.0(2)$ \\
\hline $\mathrm{O} 1-\mathrm{Na} 1-\mathrm{H} 1 \mathrm{~W}$ & $105.0(7)$ & $\mathrm{C} 4-\mathrm{C} 5-\mathrm{H} 5$ & 120.0 \\
\hline $\mathrm{O} 1^{\mathrm{iii}}-\mathrm{Na} 1-\mathrm{H} 1 \mathrm{~W}$ & $109.8(3)$ & $\mathrm{C} 6-\mathrm{C} 5-\mathrm{H} 5$ & 120.0 \\
\hline $\mathrm{O} 1 \mathrm{~W}^{\mathrm{iii}}-\mathrm{Na} 1-\mathrm{H} 1 \mathrm{~W}$ & $136.7(5)$ & $\mathrm{C} 1-\mathrm{C} 6-\mathrm{C} 5$ & $119.5(2)$ \\
\hline $\mathrm{O} 1 \mathrm{~W}-\mathrm{Na} 1-\mathrm{H} 1 \mathrm{~W}$ & $19.8(3)$ & $\mathrm{C} 1-\mathrm{C} 6-\mathrm{H} 6$ & 120.2 \\
\hline $\mathrm{S} 1-\mathrm{Na} 1-\mathrm{H} 1 \mathrm{~W}$ & $90.6(7)$ & $\mathrm{C} 5-\mathrm{C} 6-\mathrm{H} 6$ & 120.2 \\
\hline $\mathrm{O} 2-\mathrm{S} 1-\mathrm{O} 1-\mathrm{Na} 1$ & $8.38(15)$ & $\mathrm{O} 3-\mathrm{S} 1-\mathrm{C} 1-\mathrm{C} 6$ & $-17.6(2)$ \\
\hline $\mathrm{O} 3-\mathrm{S} 1-\mathrm{O} 1-\mathrm{Na} 1$ & $-121.08(12)$ & $\mathrm{O} 1-\mathrm{S} 1-\mathrm{C} 1-\mathrm{C} 6$ & $102.7(2)$ \\
\hline $\mathrm{C} 1-\mathrm{S} 1-\mathrm{O} 1-\mathrm{Na} 1$ & $123.13(11)$ & $\mathrm{Na} 1-\mathrm{S} 1-\mathrm{C} 1-\mathrm{C} 6$ & $140.94(16)$ \\
\hline
\end{tabular}




$\begin{array}{llll}\mathrm{O} 3-\mathrm{S} 1-\mathrm{O} 2-\mathrm{Na} 2 & 167.7(5) & \mathrm{C} 6-\mathrm{C} 1-\mathrm{C} 2-\mathrm{C} 3 & 1.2(3) \\ \mathrm{O} 1-\mathrm{S} 1-\mathrm{O} 2-\mathrm{Na} 2 & 38.4(5) & \mathrm{S} 1-\mathrm{C} 1-\mathrm{C} 2-\mathrm{C} 3 & -178.45(17) \\ \mathrm{C} 1-\mathrm{S} 1-\mathrm{O} 2-\mathrm{Na} 2 & -76.6(5) & \mathrm{C} 1-\mathrm{C} 2-\mathrm{C} 3-\mathrm{C} 4 & -2.4(3) \\ \mathrm{Na} 1-\mathrm{S} 1-\mathrm{O} 2-\mathrm{Na} 2 & 43.8(5) & \mathrm{C} 1-\mathrm{C} 2-\mathrm{C} 3-\mathrm{N} 1 & 178.7(2) \\ \mathrm{O} 2-\mathrm{S} 1-\mathrm{O} 3-\mathrm{Na} 1^{\mathrm{v}} & -51.3(2) & \mathrm{N} 1^{\mathrm{vi}}-\mathrm{N} 1-\mathrm{C} 3-\mathrm{C} 4 & 162.2(2) \\ \mathrm{O} 1-\mathrm{S} 1-\mathrm{O} 3-\mathrm{Na} 1^{\mathrm{v}} & 77.64(18) & \mathrm{N} 1^{\mathrm{vi}}-\mathrm{N} 1-\mathrm{C} 3-\mathrm{C} 2 & -18.9(4) \\ \mathrm{C} 1-\mathrm{S} 1-\mathrm{O} 3-\mathrm{Na}^{\mathrm{v}} & -166.65(15) & \mathrm{C} 2-\mathrm{C} 3-\mathrm{C} 4-\mathrm{C} 5 & 1.6(3) \\ \mathrm{Na} 1-\mathrm{S} 1-\mathrm{O} 3-\mathrm{Na}^{\mathrm{v}} & 35.9(2) & \mathrm{N} 1-\mathrm{C} 3-\mathrm{C} 4-\mathrm{C} 5 & -179.4(2) \\ \mathrm{O} 2-\mathrm{S} 1-\mathrm{C} 1-\mathrm{C} 2 & 41.6(2) & \mathrm{C} 3-\mathrm{C} 4-\mathrm{C} 5-\mathrm{C} 6 & 0.5(3) \\ \mathrm{O} 3-\mathrm{S} 1-\mathrm{C} 1-\mathrm{C} 2 & 162.04(18) & \mathrm{C} 2-\mathrm{C} 1-\mathrm{C} 6-\mathrm{C} 5 & 0.8(3) \\ \mathrm{O} 1-\mathrm{S} 1-\mathrm{C} 1-\mathrm{C} 2 & -77.7(2) & \mathrm{S} 1-\mathrm{C} 1-\mathrm{C} 6-\mathrm{C} 5 & -179.51(18) \\ \mathrm{Na} 1-\mathrm{S} 1-\mathrm{C} 1-\mathrm{C} 2 & -39.4(2) & \mathrm{C} 4-\mathrm{C} 5-\mathrm{C} 6-\mathrm{C} 1 & -1.7(3) \\ \mathrm{O} 2-\mathrm{S} 1-\mathrm{C} 1-\mathrm{C} 6 & -138.1(2) & & \end{array}$

Symmetry codes: (i) $x, y-1, z$; (ii) $-x, y-1,-z+1 / 2$; (iii) $-x, y,-z+1 / 2$; (iv) $-x,-y+1,-z+1$; (v) $x, y+1, z$; (vi) $-x+1 / 2,-y+1 / 2,-z+1$.

Hydrogen-bond geometry $\left(\AA,{ }^{\circ}\right)$

\begin{tabular}{lllll}
\hline$D-\mathrm{H} \cdots A$ & $D-\mathrm{H}$ & $\mathrm{H} \cdots A$ & $D \cdots A$ & $D-\mathrm{H} \cdots A$ \\
\hline $\mathrm{O} 1 W-\mathrm{H} 2 W \cdots \mathrm{O} 2 W^{\mathrm{i}}$ & $0.87(1)$ & $2.07(2)$ & $2.919(3)$ & $163(3)$ \\
$\mathrm{O} 1 W-\mathrm{H} 1 W \cdots \mathrm{O} 2^{i}$ & $0.87(1)$ & $2.29(2)$ & $3.044(3)$ & $145(3)$ \\
$\mathrm{O} 1 W-\mathrm{H} 1 W \cdots{ }^{i}$ & $0.87(1)$ & $2.32(3)$ & $3.005(3)$ & $136(3)$ \\
$\mathrm{O} 2 W-\mathrm{H} 3 W \cdots \mathrm{O} 1^{\mathrm{iii}}$ & $0.87(1)$ & $1.94(1)$ & $2.807(2)$ & $175(3)$ \\
$\mathrm{O} 2 W-\mathrm{H} 4 W \cdots \mathrm{N} 1^{\text {vii }}$ & $0.87(1)$ & $2.22(1)$ & $3.076(3)$ & $168(3)$ \\
\hline
\end{tabular}

Symmetry codes: (i) $x, y-1, z$; (iii) $-x, y,-z+1 / 2$; (vii) $x-1 / 2, y+1 / 2, z$.

catena-Poly[[tetraaquacalcium(II)]- $\mu$-3,3'-(diazane-1,2-diyl)bis(benzenesulfonato)] (II)

\section{Crystal data}

$\left[\mathrm{Ca}\left(\mathrm{C}_{12} \mathrm{H}_{8} \mathrm{~N}_{2} \mathrm{O}_{6} \mathrm{~S}_{2}\right)\left(\mathrm{H}_{2} \mathrm{O}\right)_{4}\right]$

$M_{r}=452.47$

Triclinic, $P \overline{1}$

$a=6.3875(2) \AA$

$b=6.7470(2) \AA$

$c=11.3030(5) \AA$

$\alpha=94.289(2)^{\circ}$

$\beta=103.160(2)^{\circ}$

$\gamma=108.456(2)^{\circ}$

$V=444.21(3) \AA^{3}$

Data collection

Nonius Kappa CCD diffractometer

Radiation source: sealed tube phi and $\omega$ scans

3837 measured reflections

2038 independent reflections

Refinement

Refinement on $F^{2}$

Least-squares matrix: full
$Z=1$

$F(000)=234$

$D_{\mathrm{x}}=1.691 \mathrm{Mg} \mathrm{m}^{-3}$

Mo $K \alpha$ radiation, $\lambda=0.71073 \AA$

Cell parameters from 1934 reflections

$\theta=1.0-27.5^{\circ}$

$\mu=0.65 \mathrm{~mm}^{-1}$

$T=123 \mathrm{~K}$

Plate, yellow-orange

$0.50 \times 0.25 \times 0.05 \mathrm{~mm}$

1775 reflections with $I>2 \sigma(I)$

$R_{\text {int }}=0.020$

$\theta_{\max }=27.6^{\circ}, \theta_{\min }=1.9^{\circ}$

$h=-8 \rightarrow 8$

$k=-8 \rightarrow 8$

$l=-14 \rightarrow 14$

$R\left[F^{2}>2 \sigma\left(F^{2}\right)\right]=0.027$

$w R\left(F^{2}\right)=0.070$ 
$S=1.05$

2038 reflections

140 parameters

6 restraints

Hydrogen site location: mixed
$\mathrm{H}$ atoms treated by a mixture of independent and constrained refinement

$w=1 /\left[\sigma^{2}\left(F_{\mathrm{o}}^{2}\right)+(0.0253 P)^{2}+0.2861 P\right]$ where $P=\left(F_{\mathrm{o}}{ }^{2}+2 F_{\mathrm{c}}{ }^{2}\right) / 3$

$(\Delta / \sigma)_{\max }<0.001$

$\Delta \rho_{\max }=0.40 \mathrm{e} \AA^{-3}$

$\Delta \rho_{\min }=-0.46$ e $\AA^{-3}$

Special details

Geometry. All esds (except the esd in the dihedral angle between two l.s. planes) are estimated using the full covariance matrix. The cell esds are taken into account individually in the estimation of esds in distances, angles and torsion angles; correlations between esds in cell parameters are only used when they are defined by crystal symmetry. An approximate (isotropic) treatment of cell esds is used for estimating esds involving 1.s. planes.

Fractional atomic coordinates and isotropic or equivalent isotropic displacement parameters $\left(\AA^{2}\right)$

\begin{tabular}{lllll}
\hline & $x$ & $y$ & $z$ & $U_{\text {iso }}^{*} / U_{\text {eq }}$ \\
\hline Ca1 & 0.5000 & 0.5000 & 0.5000 & $0.01202(12)$ \\
S1 & $0.81011(6)$ & $0.85257(6)$ & $0.30913(3)$ & $0.01227(11)$ \\
O1 & $0.82484(19)$ & $1.06481(17)$ & $0.35704(11)$ & $0.0180(3)$ \\
O2 & $1.03284(18)$ & $0.83889(18)$ & $0.30803(10)$ & $0.0167(2)$ \\
O3 & $0.6843(2)$ & $0.69091(18)$ & $0.37004(11)$ & $0.0202(3)$ \\
O1W & $0.8574(2)$ & $0.5188(2)$ & $0.61733(12)$ & $0.0230(3)$ \\
O2W & $0.5467(2)$ & $0.82518(18)$ & $0.61047(12)$ & $0.0229(3)$ \\
N1 & $0.0426(2)$ & $0.5479(2)$ & $-0.03915(13)$ & $0.0170(3)$ \\
C1 & $0.6455(3)$ & $0.7956(2)$ & $0.15386(14)$ & $0.0125(3)$ \\
C2 & $0.4105(3)$ & $0.6926(2)$ & $0.12544(15)$ & $0.0143(3)$ \\
H2 & 0.3369 & 0.6498 & 0.1881 & $0.017^{*}$ \\
C3 & $0.2852(3)$ & $0.6534(2)$ & $0.00261(15)$ & $0.0147(3)$ \\
C4 & $0.3926(3)$ & $0.7176(2)$ & $-0.08881(15)$ & $0.0165(3)$ \\
H4 & 0.3047 & 0.6926 & -0.1719 & $0.020^{*}$ \\
C5 & $0.6283(3)$ & $0.8181(3)$ & $-0.05911(15)$ & $0.0173(3)$ \\
H5 & 0.7019 & 0.8592 & -0.1220 & $0.021^{*}$ \\
C6 & $0.7562(3)$ & $0.8584(2)$ & $0.06276(15)$ & $0.0157(3)$ \\
H6 & 0.9173 & 0.9280 & 0.0839 & $0.019^{*}$ \\
H1W & $0.922(4)$ & $0.429(3)$ & $0.644(2)$ & $0.045(7)^{*}$ \\
H2W & $0.973(3)$ & $0.635(2)$ & $0.630(2)$ & $0.057(8)^{*}$ \\
H3W & $0.671(2)$ & $0.933(3)$ & $0.632(2)$ & $0.048(7)^{*}$ \\
H4W & $0.442(3)$ & $0.877(3)$ & $0.618(2)$ & $0.040(7)^{*}$ \\
& & & & \\
\hline
\end{tabular}

Atomic displacement parameters $\left(\AA^{2}\right)$

\begin{tabular}{lllllll}
\hline & $U^{11}$ & $U^{22}$ & $U^{33}$ & $U^{12}$ & $U^{13}$ & $U^{23}$ \\
\hline Ca1 & $0.0106(2)$ & $0.0102(2)$ & $0.0134(2)$ & $0.00197(16)$ & $0.00191(16)$ & $0.00172(16)$ \\
S1 & $0.00967(19)$ & $0.01111(19)$ & $0.01310(19)$ & $0.00092(14)$ & $0.00129(14)$ & $0.00152(14)$ \\
O1 & $0.0153(6)$ & $0.0142(6)$ & $0.0206(6)$ & $0.0038(4)$ & $0.0011(5)$ & $-0.0032(5)$ \\
O2 & $0.0114(5)$ & $0.0185(6)$ & $0.0182(6)$ & $0.0048(4)$ & $0.0008(4)$ & $0.0020(5)$ \\
O3 & $0.0173(6)$ & $0.0215(6)$ & $0.0152(6)$ & $-0.0019(5)$ & $0.0021(5)$ & $0.0072(5)$ \\
O1W & $0.0130(6)$ & $0.0183(6)$ & $0.0330(7)$ & $0.0039(5)$ & $-0.0018(5)$ & $0.0069(5)$
\end{tabular}


supporting information

\begin{tabular}{lllllll} 
O2W & $0.0156(6)$ & $0.0147(6)$ & $0.0348(7)$ & $0.0022(5)$ & $0.0067(5)$ & $-0.0055(5)$ \\
$\mathrm{N} 1$ & $0.0120(7)$ & $0.0160(7)$ & $0.0189(7)$ & $0.0020(5)$ & $0.0006(5)$ & $0.0007(5)$ \\
$\mathrm{C} 1$ & $0.0123(7)$ & $0.0093(7)$ & $0.0142(7)$ & $0.0027(6)$ & $0.0016(6)$ & $0.0014(6)$ \\
$\mathrm{C} 2$ & $0.0126(7)$ & $0.0120(7)$ & $0.0175(8)$ & $0.0036(6)$ & $0.0036(6)$ & $0.0027(6)$ \\
$\mathrm{C} 3$ & $0.0113(7)$ & $0.0120(7)$ & $0.0184(8)$ & $0.0030(6)$ & $0.0012(6)$ & $0.0013(6)$ \\
$\mathrm{C} 4$ & $0.0173(8)$ & $0.0141(8)$ & $0.0143(8)$ & $0.0038(6)$ & $-0.0003(6)$ & $0.0004(6)$ \\
$\mathrm{C} 5$ & $0.0176(8)$ & $0.0174(8)$ & $0.0163(8)$ & $0.0044(6)$ & $0.0058(6)$ & $0.0031(6)$ \\
$\mathrm{C} 6$ & $0.0124(7)$ & $0.0128(7)$ & $0.0196(8)$ & $0.0018(6)$ & $0.0035(6)$ & $0.0017(6)$ \\
\hline
\end{tabular}

Geometric parameters $\left(A,{ }^{\circ}\right)$

\begin{tabular}{|c|c|c|c|}
\hline $\mathrm{Ca} 1-\mathrm{O} 3$ & $2.3050(11)$ & $\mathrm{O} 2 \mathrm{~W}-\mathrm{H} 4 \mathrm{~W}$ & $0.863(9)$ \\
\hline $\mathrm{Ca} 1-\mathrm{O}^{\mathrm{i}}$ & $2.3051(11)$ & $\mathrm{N} 1-\mathrm{N} 1^{\mathrm{ii}}$ & $1.256(3)$ \\
\hline $\mathrm{Ca} 1-\mathrm{O} 1 \mathrm{~W}$ & $2.3235(12)$ & $\mathrm{N} 1-\mathrm{C} 3$ & $1.432(2)$ \\
\hline $\mathrm{Ca} 1-\mathrm{O} 1 \mathrm{~W}^{\mathrm{i}}$ & $2.3236(12)$ & $\mathrm{C} 1-\mathrm{C} 2$ & $1.388(2)$ \\
\hline $\mathrm{Ca} 1-\mathrm{O} 2 \mathrm{~W}^{\mathrm{i}}$ & $2.3385(12)$ & $\mathrm{C} 1-\mathrm{C} 6$ & $1.395(2)$ \\
\hline $\mathrm{Ca} 1-\mathrm{O} 2 \mathrm{~W}$ & $2.3385(12)$ & $\mathrm{C} 2-\mathrm{C} 3$ & $1.394(2)$ \\
\hline $\mathrm{S} 1-\mathrm{O} 3$ & $1.4556(11)$ & $\mathrm{C} 2-\mathrm{H} 2$ & 0.9500 \\
\hline $\mathrm{S} 1-\mathrm{O} 2$ & $1.4573(12)$ & $\mathrm{C} 3-\mathrm{C} 4$ & $1.388(2)$ \\
\hline $\mathrm{S} 1-\mathrm{O} 1$ & $1.4588(12)$ & $\mathrm{C} 4-\mathrm{C} 5$ & $1.388(2)$ \\
\hline $\mathrm{S} 1-\mathrm{C} 1$ & $1.7711(16)$ & $\mathrm{C} 4-\mathrm{H} 4$ & 0.9500 \\
\hline $\mathrm{O} 1 \mathrm{~W}-\mathrm{H} 1 \mathrm{~W}$ & $0.870(9)$ & $\mathrm{C} 5-\mathrm{C} 6$ & $1.389(2)$ \\
\hline $\mathrm{O} 1 \mathrm{~W}-\mathrm{H} 2 \mathrm{~W}$ & $0.864(10)$ & $\mathrm{C} 5-\mathrm{H} 5$ & 0.9500 \\
\hline $\mathrm{O} 2 \mathrm{~W}-\mathrm{H} 3 \mathrm{~W}$ & $0.862(10)$ & $\mathrm{C} 6-\mathrm{H} 6$ & 0.9500 \\
\hline $\mathrm{O} 3-\mathrm{Ca} 1-\mathrm{O} 3^{\mathrm{i}}$ & 180.0 & $\mathrm{H} 1 \mathrm{~W}-\mathrm{O} 1 \mathrm{~W}-\mathrm{H} 2 \mathrm{~W}$ & $102.3(17)$ \\
\hline $\mathrm{O} 3-\mathrm{Ca} 1-\mathrm{O} 1 \mathrm{~W}$ & $87.66(4)$ & $\mathrm{Ca} 1-\mathrm{O} 2 \mathrm{~W}-\mathrm{H} 3 \mathrm{~W}$ & $125.5(15)$ \\
\hline $\mathrm{O}^{\mathrm{i}}-\mathrm{Ca} 1-\mathrm{O} 1 \mathrm{~W}$ & $92.34(4)$ & $\mathrm{Ca} 1-\mathrm{O} 2 \mathrm{~W}-\mathrm{H} 4 \mathrm{~W}$ & $127.9(15)$ \\
\hline $\mathrm{O} 3-\mathrm{Ca} 1-\mathrm{O} 1 \mathrm{~W}^{\mathrm{i}}$ & $92.34(4)$ & $\mathrm{H} 3 \mathrm{~W}-\mathrm{O} 2 \mathrm{~W}-\mathrm{H} 4 \mathrm{~W}$ & $103.9(17)$ \\
\hline $\mathrm{O} 3^{\mathrm{i}}-\mathrm{Ca} 1-\mathrm{O} 1 \mathrm{~W}^{\mathrm{i}}$ & $87.66(4)$ & $\mathrm{N} 1 \mathrm{ii}-\mathrm{N} 1-\mathrm{C} 3$ & $113.72(17)$ \\
\hline $\mathrm{O} 1 \mathrm{~W}-\mathrm{Ca} 1-\mathrm{O} 1 \mathrm{~W}^{\mathrm{i}}$ & $180.00(6)$ & $\mathrm{C} 2-\mathrm{C} 1-\mathrm{C} 6$ & $121.50(14)$ \\
\hline $\mathrm{O} 3-\mathrm{Ca} 1-\mathrm{O} 2 \mathrm{~W}^{\mathrm{i}}$ & $93.07(4)$ & $\mathrm{C} 2-\mathrm{C} 1-\mathrm{S} 1$ & $119.72(12)$ \\
\hline $\mathrm{O} 3-\mathrm{Ca} 1-\mathrm{O} 2 \mathrm{~W}^{\mathrm{i}}$ & $86.93(5)$ & $\mathrm{C} 6-\mathrm{C} 1-\mathrm{S} 1$ & $118.78(12)$ \\
\hline $\mathrm{O} 1 \mathrm{~W}-\mathrm{Ca} 1-\mathrm{O} 2 \mathrm{~W}^{\mathrm{i}}$ & $90.52(5)$ & $\mathrm{C} 1-\mathrm{C} 2-\mathrm{C} 3$ & $118.31(15)$ \\
\hline $\mathrm{O} 1 \mathrm{~W}^{\mathrm{i}}-\mathrm{Ca} 1-\mathrm{O} 2 \mathrm{~W}^{\mathrm{i}}$ & $89.48(5)$ & $\mathrm{C} 1-\mathrm{C} 2-\mathrm{H} 2$ & 120.8 \\
\hline $\mathrm{O} 3-\mathrm{Ca} 1-\mathrm{O} 2 \mathrm{~W}$ & $86.93(5)$ & $\mathrm{C} 3-\mathrm{C} 2-\mathrm{H} 2$ & 120.8 \\
\hline $\mathrm{O}^{\mathrm{i}}-\mathrm{Ca} 1-\mathrm{O} 2 \mathrm{~W}$ & $93.07(4)$ & $\mathrm{C} 4-\mathrm{C} 3-\mathrm{C} 2$ & $120.82(14)$ \\
\hline $\mathrm{O} 1 \mathrm{~W}-\mathrm{Ca} 1-\mathrm{O} 2 \mathrm{~W}$ & $89.48(5)$ & $\mathrm{C} 4-\mathrm{C} 3-\mathrm{N} 1$ & $115.24(14)$ \\
\hline $\mathrm{O} 1 \mathrm{~W}-\mathrm{Ca} 1-\mathrm{O} 2 \mathrm{~W}$ & $90.52(5)$ & $\mathrm{C} 2-\mathrm{C} 3-\mathrm{N} 1$ & $123.94(15)$ \\
\hline $\mathrm{O} 2 \mathrm{~W}^{\mathrm{i}}-\mathrm{Ca} 1-\mathrm{O} 2 \mathrm{~W}$ & 180.0 & $\mathrm{C} 3-\mathrm{C} 4-\mathrm{C} 5$ & $120.17(15)$ \\
\hline $\mathrm{O} 3-\mathrm{S} 1-\mathrm{O} 2$ & $112.30(7)$ & $\mathrm{C} 3-\mathrm{C} 4-\mathrm{H} 4$ & 119.9 \\
\hline $\mathrm{O} 3-\mathrm{S} 1-\mathrm{O} 1$ & $112.52(7)$ & $\mathrm{C} 5-\mathrm{C} 4-\mathrm{H} 4$ & 119.9 \\
\hline $\mathrm{O} 2-\mathrm{S} 1-\mathrm{O} 1$ & $112.61(7)$ & $\mathrm{C} 4-\mathrm{C} 5-\mathrm{C} 6$ & $119.87(15)$ \\
\hline $\mathrm{O} 3-\mathrm{S} 1-\mathrm{C} 1$ & $105.40(7)$ & $\mathrm{C} 4-\mathrm{C} 5-\mathrm{H} 5$ & 120.1 \\
\hline $\mathrm{O} 2-\mathrm{S} 1-\mathrm{C} 1$ & $106.74(7)$ & $\mathrm{C} 6-\mathrm{C} 5-\mathrm{H} 5$ & 120.1 \\
\hline $\mathrm{O} 1-\mathrm{S} 1-\mathrm{C} 1$ & $106.66(7)$ & $\mathrm{C} 5-\mathrm{C} 6-\mathrm{C} 1$ & $119.31(14)$ \\
\hline $\mathrm{S} 1-\mathrm{O} 3-\mathrm{Ca} 1$ & $166.87(8)$ & $\mathrm{C} 5-\mathrm{C} 6-\mathrm{H} 6$ & 120.3 \\
\hline $\mathrm{Ca} 1-\mathrm{O} 1 \mathrm{~W}-\mathrm{H} 1 \mathrm{~W}$ & $136.4(15)$ & $\mathrm{C} 1-\mathrm{C} 6-\mathrm{H} 6$ & 120.3 \\
\hline
\end{tabular}




$\begin{array}{ll}\mathrm{Ca} 1-\mathrm{O} 1 \mathrm{~W}-\mathrm{H} 2 \mathrm{~W} & 120.0(16) \\ \mathrm{O} 2-\mathrm{S} 1-\mathrm{O} 3-\mathrm{Ca} 1 & 111.4(3) \\ \mathrm{O} 1-\mathrm{S} 1-\mathrm{O} 3-\mathrm{Ca} 1 & -16.9(4) \\ \mathrm{C} 1-\mathrm{S} 1-\mathrm{O} 3-\mathrm{Ca} 1 & -132.8(3) \\ \mathrm{O} 3-\mathrm{S} 1-\mathrm{C} 1-\mathrm{C} 2 & 27.51(14) \\ \mathrm{O} 2-\mathrm{S} 1-\mathrm{C} 1-\mathrm{C} 2 & 147.11(12) \\ \mathrm{O} 1-\mathrm{S} 1-\mathrm{C} 1-\mathrm{C} 2 & -92.29(13) \\ \mathrm{O} 3-\mathrm{S} 1-\mathrm{C} 1-\mathrm{C} 6 & -153.27(13) \\ \mathrm{O} 2-\mathrm{S} 1-\mathrm{C} 1-\mathrm{C} 6 & -33.67(14) \\ \mathrm{O} 1-\mathrm{S} 1-\mathrm{C} 1-\mathrm{C} 6 & 86.93(13) \\ \mathrm{C} 6-\mathrm{C} 1-\mathrm{C} 2-\mathrm{C} 3 & -0.3(2) \\ \mathrm{S} 1-\mathrm{C} 1-\mathrm{C} 2-\mathrm{C} 3 & 178.88(11)\end{array}$

$$
\begin{array}{ll}
\mathrm{C} 1-\mathrm{C} 2-\mathrm{C} 3-\mathrm{C} 4 & -0.6(2) \\
\mathrm{C} 1-\mathrm{C} 2-\mathrm{C} 3-\mathrm{N} 1 & 179.69(14) \\
\mathrm{N} 1{ }^{\mathrm{ii}}-\mathrm{N} 1-\mathrm{C} 3-\mathrm{C} 4 & 165.42(17) \\
\mathrm{N} 1{ }^{\mathrm{i}-}-\mathrm{N} 1-\mathrm{C} 3-\mathrm{C} 2 & -14.8(3) \\
\mathrm{C} 2-\mathrm{C} 3-\mathrm{C} 4-\mathrm{C} 5 & 1.4(2) \\
\mathrm{N} 1-\mathrm{C} 3-\mathrm{C} 4-\mathrm{C} 5 & -178.84(14) \\
\mathrm{C} 3-\mathrm{C} 4-\mathrm{C} 5-\mathrm{C} 6 & -1.3(2) \\
\mathrm{C} 4-\mathrm{C} 5-\mathrm{C} 6-\mathrm{C} 1 & 0.4(2) \\
\mathrm{C} 2-\mathrm{C} 1-\mathrm{C} 6-\mathrm{C} 5 & 0.4(2) \\
\mathrm{S} 1-\mathrm{C} 1-\mathrm{C} 6-\mathrm{C} 5 & -178.82(12)
\end{array}
$$$$
-0.6(2)
$$$$
\mathrm{N} 1{ }^{\mathrm{ii}}-\mathrm{N} 1-\mathrm{C} 3-\mathrm{C} 4
$$$$
\mathrm{C} 2-\mathrm{C} 3-\mathrm{C} 4-\mathrm{C} 5
$$$$
\mathrm{C} 3-\mathrm{C} 4-\mathrm{C} 5-\mathrm{C} 6 \quad-1.3(2)
$$$$
\mathrm{C} 2-\mathrm{C} 1-\mathrm{C} 6-\mathrm{C} 5
$$

Symmetry codes: (i) $-x+1,-y+1,-z+1$; (ii) $-x,-y+1,-z$.

Hydrogen-bond geometry $\left(\AA,{ }^{\circ}\right)$

\begin{tabular}{lllll}
\hline$D-\mathrm{H} \cdots A$ & $D-\mathrm{H}$ & $\mathrm{H} \cdots A$ & $D \cdots A$ & $D-\mathrm{H} \cdots A$ \\
\hline $\mathrm{O} 1 W-\mathrm{H} 1 W \cdots \mathrm{O} 2^{\mathrm{iii}}$ & $0.87(1)$ & $2.01(1)$ & $2.8521(17)$ & $162(2)$ \\
$\mathrm{O} 1 W-\mathrm{H} 2 W \cdots \mathrm{O} 1^{\text {iv }}$ & $0.86(1)$ & $2.00(1)$ & $2.8454(17)$ & $165(2)$ \\
$\mathrm{O} 2 W-\mathrm{H} 3 W \cdots \mathrm{O} 2^{\text {iv }}$ & $0.86(1)$ & $1.95(1)$ & $2.8119(16)$ & $174(2)$ \\
$\mathrm{O} 2 W-\mathrm{H} 4 W \cdots{ }^{v}$ & $0.86(1)$ & $1.94(1)$ & $2.7907(16)$ & $168(2)$
\end{tabular}

Symmetry codes: (iii) $-x+2,-y+1,-z+1$; (iv) $-x+2,-y+2,-z+1$; (v) $-x+1,-y+2,-z+1$.

catena-Poly[[[diaquacalcium(II)]- $\mu$-2-(4-amino-3-sulfonatophenyl)-\1-(4-sulfonatophenyl)diazenium] dihydrate] (III)

\section{Crystal data}

$\left[\mathrm{Na}\left(\mathrm{C}_{12} \mathrm{H}_{10} \mathrm{~N}_{3} \mathrm{O}_{6} \mathrm{~S}_{2}\right)\left(\mathrm{H}_{2} \mathrm{O}\right)_{2}\right] \cdot 2 \mathrm{H}_{2} \mathrm{O}$

$M_{r}=451.40$

Monoclinic, $P 2{ }_{1} / c$

$a=13.9454(18) \AA$

$b=19.517$ (3) $\AA$

$c=6.9014(9) \AA$

$\beta=93.838(2)^{\circ}$

$V=1874.2(4) \AA^{3}$

$Z=4$

$$
F(000)=936
$$

$D_{\mathrm{x}}=1.600 \mathrm{Mg} \mathrm{m}^{-3}$

Synchrotron radiation, $\lambda=0.6775 \AA$

Cell parameters from 8092 reflections

$\theta=1.4-24.3^{\circ}$

$\mu=0.32 \mathrm{~mm}^{-1}$

$T=150 \mathrm{~K}$

Fibre, red

$0.50 \times 0.01 \times 0.01 \mathrm{~mm}$

Data collection

APEXII

diffractometer

Radiation source: Station 9.8 Daresbury SRS

$\omega$ scans

Absorption correction: multi-scan

(SADABS; Bruker, 2012)

$T_{\min }=0.676, T_{\max }=1.000$

15360 measured reflections
3531 independent reflections

2772 reflections with $I>2 \sigma(I)$

$R_{\text {int }}=0.049$

$\theta_{\max }=24.3^{\circ}, \theta_{\min }=1.4^{\circ}$

$h=-16 \rightarrow 16$

$k=-23 \rightarrow 23$

$l=-8 \rightarrow 8$ 


\section{Refinement}

Refinement on $F^{2}$

Least-squares matrix: full

$R\left[F^{2}>2 \sigma\left(F^{2}\right)\right]=0.040$

$w R\left(F^{2}\right)=0.107$

$S=1.04$

3531 reflections

311 parameters

15 restraints
Hydrogen site location: mixed

$\mathrm{H}$ atoms treated by a mixture of independent and constrained refinement

$w=1 /\left[\sigma^{2}\left(F_{\mathrm{o}}{ }^{2}\right)+(0.0583 P)^{2}+0.7405 P\right]$

where $P=\left(F_{\mathrm{o}}^{2}+2 F_{\mathrm{c}}^{2}\right) / 3$

$(\Delta / \sigma)_{\max }<0.001$

$\Delta \rho_{\max }=0.35 \mathrm{e}^{-3}$

$\Delta \rho_{\min }=-0.44$ e $\AA^{-3}$

Special details

Geometry. All esds (except the esd in the dihedral angle between two 1.s. planes) are estimated using the full covariance matrix. The cell esds are taken into account individually in the estimation of esds in distances, angles and torsion angles; correlations between esds in cell parameters are only used when they are defined by crystal symmetry. An approximate (isotropic) treatment of cell esds is used for estimating esds involving l.s. planes.

Fractional atomic coordinates and isotropic or equivalent isotropic displacement parameters $\left(\AA^{2}\right)$

\begin{tabular}{|c|c|c|c|c|c|}
\hline & $x$ & $y$ & $z$ & $U_{\text {iso }} * / U_{\text {eq }}$ & Occ. $(<1)$ \\
\hline $\mathrm{Na} 1$ & $0.12675(8)$ & $0.22691(6)$ & $0.23165(16)$ & $0.0383(3)$ & \\
\hline S1 & $-0.39901(4)$ & $-0.11626(3)$ & $0.25342(9)$ & $0.02313(17)$ & \\
\hline S2 & $0.01324(4)$ & $0.38021(3)$ & $0.06796(9)$ & $0.02399(17)$ & \\
\hline $\mathrm{O} 1$ & $-0.33121(14)$ & $-0.14369(9)$ & $0.4031(3)$ & $0.0352(5)$ & \\
\hline $\mathrm{O} 2$ & $-0.49783(13)$ & $-0.12523(9)$ & $0.2974(3)$ & $0.0348(5)$ & \\
\hline $\mathrm{O} 3$ & $-0.38045(12)$ & $-0.14348(8)$ & $0.0621(3)$ & $0.0276(4)$ & \\
\hline $\mathrm{O} 4$ & $-0.00470(13)$ & $0.42439(8)$ & $-0.1002(3)$ & $0.0295(4)$ & \\
\hline O5 & $0.06200(12)$ & $0.41576(10)$ & $0.2293(3)$ & $0.0344(5)$ & \\
\hline O6 & $0.05796(12)$ & $0.31539(9)$ & $0.0222(3)$ & $0.0291(4)$ & \\
\hline $\mathrm{O} 1 \mathrm{~W}$ & $0.02623(18)$ & $0.15088(11)$ & $0.0719(3)$ & $0.0463(5)$ & \\
\hline $\mathrm{O} 2 \mathrm{~W}$ & $0.23561(13)$ & $0.23836(9)$ & $-0.0156(3)$ & $0.0301(4)$ & \\
\hline $\mathrm{O} 3 \mathrm{~W}$ & $0.53321(13)$ & $0.24230(9)$ & $0.4670(3)$ & 0.0319 (4) & \\
\hline $\mathrm{O} 4 \mathrm{~W}$ & $-0.2986(10)$ & $0.5679(6)$ & $0.2536(7)$ & $0.036(2)$ & $0.67(4)$ \\
\hline $\mathrm{H} 7 \mathrm{~W}$ & $-0.322(3)$ & $0.593(2)$ & $0.344(5)$ & $0.043^{*}$ & 0.6659 \\
\hline $\mathrm{H} 8 \mathrm{~W}$ & $-0.308(4)$ & $0.594(2)$ & $0.152(4)$ & $0.043^{*}$ & 0.6659 \\
\hline $\mathrm{O} 5 \mathrm{~W}$ & $-0.258(2)$ & $0.5945(15)$ & $0.2586(13)$ & $0.043(6)$ & $0.33(4)$ \\
\hline H9W & $-0.294(6)$ & $0.614(5)$ & $0.343(11)$ & $0.052 *$ & 0.3341 \\
\hline H10W & $-0.287(7)$ & $0.611(5)$ & $0.151(8)$ & $0.052 *$ & 0.3341 \\
\hline N1 & $-0.32011(15)$ & $0.18160(10)$ & $0.2481(3)$ & $0.0226(4)$ & \\
\hline $\mathrm{N} 2$ & $-0.23798(14)$ & $0.20549(10)$ & $0.2029(3)$ & $0.0228(5)$ & \\
\hline N3 & $-0.14295(18)$ & $0.47735(11)$ & $0.1967(3)$ & $0.0271(5)$ & \\
\hline $\mathrm{C} 1$ & $-0.37563(17)$ & $-0.02746(12)$ & $0.2466(3)$ & $0.0210(5)$ & \\
\hline $\mathrm{C} 2$ & $-0.45031(17)$ & 0.01909 (12) & $0.2548(4)$ & $0.0254(5)$ & \\
\hline $\mathrm{H} 2$ & -0.5145 & 0.0034 & 0.2609 & $0.030^{*}$ & \\
\hline $\mathrm{C} 3$ & $-0.43073(17)$ & $0.08833(12)$ & $0.2541(4)$ & $0.0255(5)$ & \\
\hline $\mathrm{H} 3$ & -0.4813 & 0.1207 & 0.2599 & $0.031^{*}$ & \\
\hline $\mathrm{C} 4$ & $-0.33685(18)$ & $0.11031(11)$ & $0.2448(4)$ & $0.0222(5)$ & \\
\hline $\mathrm{C} 5$ & $-0.26117(18)$ & $0.06385(12)$ & $0.2347(4)$ & $0.0244(5)$ & \\
\hline H5 & -0.1971 & 0.0796 & 0.2271 & $0.029 *$ & \\
\hline C6 & $-0.28139(17)$ & $-0.00534(12)$ & $0.2358(4)$ & $0.0238(5)$ & \\
\hline
\end{tabular}




$\begin{array}{lllll}\text { H6 } & -0.2310 & -0.0378 & 0.2293 & 0.029^{*} \\ \text { C7 } & -0.22223(17) & 0.27328(12) & 0.2046(3) & 0.0205(5) \\ \text { C8 } & -0.12979(17) & 0.29210(12) & 0.1488(3) & 0.0206(5) \\ \text { H8 } & -0.0862 & 0.2573 & 0.1151 & 0.025^{*} \\ \text { C9 } & -0.10223(16) & 0.35880(12) & 0.1425(3) & 0.0212(5) \\ \text { C10 } & -0.16655(17) & 0.41207(12) & 0.1950(3) & 0.0215(5) \\ \text { C11 } & -0.26021(17) & 0.39255(12) & 0.2479(4) & 0.0229(5) \\ \text { H11 } & -0.3045 & 0.4271 & 0.2796 & 0.027^{*} \\ \text { C12 } & -0.28719(17) & 0.32635(12) & 0.2540(3) & 0.0217(5) \\ \text { H12 } & -0.3496 & 0.3148 & 0.2911 & 0.026^{*} \\ \text { H3N } & -0.092(2) & 0.4909(17) & 0.164(5) & 0.047(10)^{*} \\ \text { H1N } & -0.365(2) & 0.2073(15) & 0.279(4) & 0.027(7)^{*} \\ \text { H2N } & -0.184(2) & 0.5049(16) & 0.224(4) & 0.037(9)^{*} \\ \text { H2W } & 0.006(3) & 0.1202(15) & 0.153(5) & 0.103(17)^{*} \\ \text { H5W } & 0.511(2) & 0.2091(11) & 0.534(4) & 0.059(11)^{*} \\ \text { H3W } & 0.2823(16) & 0.2095(12) & -0.036(5) & 0.064(11)^{*} \\ \text { H4W } & 0.2700(19) & 0.2733(10) & 0.028(5) & 0.056(11)^{*} \\ \text { H6W } & 0.4863(17) & 0.2716(13) & 0.466(5) & 0.066(12)^{*} \\ \text { H1W } & 0.046(3) & 0.1233(15) & -0.019(4) & 0.077(14)^{*} \\ & & & \end{array}$

Atomic displacement parameters $\left(\AA^{2}\right)$

\begin{tabular}{lllllll}
\hline & $U^{11}$ & $U^{22}$ & $U^{33}$ & $U^{12}$ & $U^{13}$ & $U^{23}$ \\
\hline Na1 & $0.0349(6)$ & $0.0465(7)$ & $0.0334(6)$ & $-0.0113(5)$ & $0.0016(5)$ & $0.0046(5)$ \\
S1 & $0.0273(3)$ & $0.0131(3)$ & $0.0294(4)$ & $-0.0020(2)$ & $0.0045(3)$ & $0.0000(2)$ \\
S2 & $0.0222(3)$ & $0.0193(3)$ & $0.0313(4)$ & $-0.0031(2)$ & $0.0076(2)$ & $-0.0007(3)$ \\
O1 & $0.0504(12)$ & $0.0183(9)$ & $0.0358(11)$ & $0.0020(8)$ & $-0.0061(9)$ & $0.0040(8)$ \\
O2 & $0.0329(10)$ & $0.0202(9)$ & $0.0530(12)$ & $-0.0064(8)$ & $0.0160(9)$ & $-0.0027(9)$ \\
O3 & $0.0337(10)$ & $0.0185(9)$ & $0.0312(10)$ & $0.0008(7)$ & $0.0060(8)$ & $-0.0034(7)$ \\
O4 & $0.0341(10)$ & $0.0196(9)$ & $0.0358(10)$ & $-0.0010(7)$ & $0.0108(8)$ & $0.0047(8)$ \\
O5 & $0.0276(10)$ & $0.0366(11)$ & $0.0392(11)$ & $-0.0094(8)$ & $0.0042(8)$ & $-0.0066(9)$ \\
O6 & $0.0257(9)$ & $0.0207(9)$ & $0.0418(11)$ & $0.0020(7)$ & $0.0100(8)$ & $0.0018(8)$ \\
O1W & $0.0674(16)$ & $0.0345(12)$ & $0.0368(12)$ & $-0.0072(11)$ & $0.0022(11)$ & $0.0001(10)$ \\
O2W & $0.0280(10)$ & $0.0235(10)$ & $0.0390(11)$ & $0.0017(8)$ & $0.0034(8)$ & $-0.0046(8)$ \\
O3W & $0.0327(11)$ & $0.0221(9)$ & $0.0421(11)$ & $0.0030(8)$ & $0.0123(9)$ & $0.0091(9)$ \\
O4W & $0.044(5)$ & $0.032(4)$ & $0.032(2)$ & $0.015(3)$ & $0.0048(19)$ & $-0.0011(18)$ \\
O5W & $0.048(9)$ & $0.045(9)$ & $0.036(4)$ & $0.020(8)$ & $-0.003(4)$ & $-0.006(4)$ \\
N1 & $0.0237(11)$ & $0.0151(10)$ & $0.0294(12)$ & $-0.0020(9)$ & $0.0046(9)$ & $0.0010(9)$ \\
N2 & $0.0252(11)$ & $0.0179(10)$ & $0.0252(11)$ & $-0.0033(8)$ & $0.0014(9)$ & $0.0011(8)$ \\
N3 & $0.0262(12)$ & $0.0159(11)$ & $0.0401(14)$ & $-0.0010(10)$ & $0.0099(10)$ & $-0.0005(10)$ \\
C1 & $0.0246(12)$ & $0.0139(11)$ & $0.0244(12)$ & $-0.0020(9)$ & $0.0017(10)$ & $0.0000(9)$ \\
C2 & $0.0234(12)$ & $0.0196(12)$ & $0.0331(14)$ & $-0.0043(10)$ & $0.0020(10)$ & $-0.0012(10)$ \\
C3 & $0.0240(13)$ & $0.0199(12)$ & $0.0328(14)$ & $0.0020(10)$ & $0.0021(11)$ & $0.0000(11)$ \\
C4 & $0.0288(13)$ & $0.0139(11)$ & $0.0241(13)$ & $-0.0021(10)$ & $0.0023(10)$ & $0.0006(10)$ \\
C5 & $0.0211(12)$ & $0.0215(13)$ & $0.0309(14)$ & $-0.0035(10)$ & $0.0034(10)$ & $0.0011(11)$ \\
C6 & $0.0224(12)$ & $0.0184(12)$ & $0.0308(13)$ & $0.0023(9)$ & $0.0029(10)$ & $0.0013(10)$ \\
C7 & $0.0219(12)$ & $0.0161(12)$ & $0.0234(12)$ & $-0.0024(9)$ & $0.0005(10)$ & $-0.0005(9)$ \\
C8 & $0.0230(12)$ & $0.0163(12)$ & $0.0225(12)$ & $0.0003(9)$ & $0.0018(10)$ & $-0.0006(9)$ \\
& & & & & &
\end{tabular}


supporting information

\begin{tabular}{lllllll} 
C9 & $0.0202(12)$ & $0.0182(12)$ & $0.0253(13)$ & $-0.0015(9)$ & $0.0028(10)$ & $0.0003(10)$ \\
C10 & $0.0255(12)$ & $0.0165(12)$ & $0.0226(12)$ & $-0.0011(10)$ & $0.0013(10)$ & $0.0022(10)$ \\
C11 & $0.0245(12)$ & $0.0182(12)$ & $0.0264(13)$ & $0.0028(9)$ & $0.0044(10)$ & $0.0006(10)$ \\
C12 & $0.0204(12)$ & $0.0206(12)$ & $0.0244(13)$ & $-0.0013(9)$ & $0.0035(10)$ & $0.0008(10)$ \\
\hline
\end{tabular}

Geometric parameters $\left(\AA,{ }^{\circ}\right)$

\begin{tabular}{|c|c|c|c|}
\hline $\mathrm{Na} 1-\mathrm{O} 1 \mathrm{~W}$ & $2.275(2)$ & $\mathrm{O} 5 \mathrm{~W}-\mathrm{H} 10 \mathrm{~W}$ & $0.879(10)$ \\
\hline $\mathrm{Na} 1-\mathrm{O} 2 \mathrm{~W}^{\mathrm{i}}$ & $2.335(2)$ & $\mathrm{N} 1-\mathrm{N} 2$ & $1.294(3)$ \\
\hline $\mathrm{Na} 1-\mathrm{O} 2 \mathrm{~W}$ & $2.369(2)$ & $\mathrm{N} 1-\mathrm{C} 4$ & $1.411(3)$ \\
\hline $\mathrm{Na} 1-\mathrm{O} 6$ & $2.409(2)$ & N1-H1N & $0.84(3)$ \\
\hline $\mathrm{Na} 1-\mathrm{O}^{\mathrm{i}}$ & $2.425(2)$ & $\mathrm{N} 2-\mathrm{C} 7$ & $1.341(3)$ \\
\hline $\mathrm{Na} 1-\mathrm{Na} 1^{\mathrm{ii}}$ & $3.5664(7)$ & $\mathrm{N} 3-\mathrm{C} 10$ & $1.316(3)$ \\
\hline $\mathrm{Na} 1-\mathrm{Na} 1^{\mathrm{i}}$ & $3.5665(7)$ & $\mathrm{N} 3-\mathrm{H} 3 \mathrm{~N}$ & $0.81(3)$ \\
\hline $\mathrm{Na} 1-\mathrm{H} 4 \mathrm{~W}$ & $2.68(3)$ & $\mathrm{N} 3-\mathrm{H} 2 \mathrm{~N}$ & $0.82(3)$ \\
\hline $\mathrm{S} 1-\mathrm{O} 2$ & $1.4415(18)$ & $\mathrm{C} 1-\mathrm{C} 2$ & $1.386(3)$ \\
\hline $\mathrm{S} 1-\mathrm{O} 1$ & $1.4552(19)$ & $\mathrm{C} 1-\mathrm{C} 6$ & $1.390(3)$ \\
\hline $\mathrm{S} 1-\mathrm{O} 3$ & $1.4623(18)$ & $\mathrm{C} 2-\mathrm{C} 3$ & $1.379(3)$ \\
\hline $\mathrm{S} 1-\mathrm{C} 1$ & $1.765(2)$ & $\mathrm{C} 2-\mathrm{H} 2$ & 0.9500 \\
\hline $\mathrm{S} 2-\mathrm{O} 5$ & $1.4430(19)$ & $\mathrm{C} 3-\mathrm{C} 4$ & $1.383(3)$ \\
\hline $\mathrm{S} 2-\mathrm{O} 4$ & $1.4541(18)$ & $\mathrm{C} 3-\mathrm{H} 3$ & 0.9500 \\
\hline $\mathrm{S} 2-\mathrm{O} 6$ & $1.4545(18)$ & $\mathrm{C} 4-\mathrm{C} 5$ & $1.397(3)$ \\
\hline $\mathrm{S} 2-\mathrm{C} 9$ & $1.773(2)$ & $\mathrm{C} 5-\mathrm{C} 6$ & $1.380(3)$ \\
\hline $\mathrm{O} 6-\mathrm{Na} 1^{\mathrm{ii}}$ & $2.425(2)$ & $\mathrm{C} 5-\mathrm{H} 5$ & 0.9500 \\
\hline $\mathrm{O} 1 \mathrm{~W}-\mathrm{H} 2 \mathrm{~W}$ & $0.878(10)$ & $\mathrm{C} 6-\mathrm{H} 6$ & 0.9500 \\
\hline $\mathrm{O} 1 \mathrm{~W}-\mathrm{H} 1 \mathrm{~W}$ & $0.883(10)$ & $\mathrm{C} 7-\mathrm{C} 8$ & $1.418(3)$ \\
\hline $\mathrm{O} 2 \mathrm{~W}-\mathrm{Na} 1^{\mathrm{ii}}$ & $2.335(2)$ & $\mathrm{C} 7-\mathrm{C} 12$ & $1.432(3)$ \\
\hline $\mathrm{O} 2 \mathrm{~W}-\mathrm{H} 3 \mathrm{~W}$ & $0.879(10)$ & $\mathrm{C} 8-\mathrm{C} 9$ & $1.359(3)$ \\
\hline $\mathrm{O} 2 \mathrm{~W}-\mathrm{H} 4 \mathrm{~W}$ & $0.876(10)$ & $\mathrm{C} 8-\mathrm{H} 8$ & 0.9500 \\
\hline $\mathrm{O} 3 \mathrm{~W}-\mathrm{H} 5 \mathrm{~W}$ & $0.863(10)$ & $\mathrm{C} 9-\mathrm{C} 10$ & $1.435(3)$ \\
\hline $\mathrm{O} 3 \mathrm{~W}-\mathrm{H} 6 \mathrm{~W}$ & $0.869(10)$ & $\mathrm{C} 10-\mathrm{C} 11$ & $1.431(3)$ \\
\hline $\mathrm{O} 4 \mathrm{~W}-\mathrm{H} 7 \mathrm{~W}$ & $0.875(10)$ & $\mathrm{C} 11-\mathrm{C} 12$ & $1.347(3)$ \\
\hline $\mathrm{O} 4 \mathrm{~W}-\mathrm{H} 8 \mathrm{~W}$ & $0.876(10)$ & $\mathrm{C} 11-\mathrm{H} 11$ & 0.9500 \\
\hline $\mathrm{O} 5 \mathrm{~W}-\mathrm{H} 9 \mathrm{~W}$ & $0.878(10)$ & $\mathrm{C} 12-\mathrm{H} 12$ & 0.9500 \\
\hline $\mathrm{O} 1 \mathrm{~W}-\mathrm{Na} 1-\mathrm{O} 2 \mathrm{~W}^{\mathrm{i}}$ & $154.18(9)$ & $\mathrm{Na} 1^{\mathrm{ii}}-\mathrm{O} 2 \mathrm{~W}-\mathrm{H} 4 \mathrm{~W}$ & $110(2)$ \\
\hline $\mathrm{O} 1 \mathrm{~W}-\mathrm{Na} 1-\mathrm{O} 2 \mathrm{~W}$ & $96.67(9)$ & $\mathrm{Na} 1-\mathrm{O} 2 \mathrm{~W}-\mathrm{H} 4 \mathrm{~W}$ & $101(2)$ \\
\hline $\mathrm{O} 2 \mathrm{~W}^{\mathrm{i}}-\mathrm{Na} 1-\mathrm{O} 2 \mathrm{~W}$ & $95.44(7)$ & $\mathrm{H} 3 \mathrm{~W}-\mathrm{O} 2 \mathrm{~W}-\mathrm{H} 4 \mathrm{~W}$ & $99.1(19)$ \\
\hline $\mathrm{O} 1 \mathrm{~W}-\mathrm{Na} 1-\mathrm{O} 6$ & $88.23(8)$ & $\mathrm{H} 5 \mathrm{~W}-\mathrm{O} 3 \mathrm{~W}-\mathrm{H} 6 \mathrm{~W}$ & $102(2)$ \\
\hline $\mathrm{O} 2 \mathrm{~W}^{\mathrm{i}}-\mathrm{Na} 1-\mathrm{O} 6$ & $116.93(8)$ & $\mathrm{H} 7 \mathrm{~W}-\mathrm{O} 4 \mathrm{~W}-\mathrm{H} 8 \mathrm{~W}$ & $101(2)$ \\
\hline $\mathrm{O} 2 \mathrm{~W}-\mathrm{Na} 1-\mathrm{O} 6$ & $75.46(7)$ & $\mathrm{H} 9 \mathrm{~W}-\mathrm{O} 5 \mathrm{~W}-\mathrm{H} 10 \mathrm{~W}$ & $99(2)$ \\
\hline $\mathrm{O} 1 \mathrm{~W}-\mathrm{Na} 1-\mathrm{O}^{\mathrm{i}}$ & $85.06(8)$ & $\mathrm{N} 2-\mathrm{N} 1-\mathrm{C} 4$ & $120.0(2)$ \\
\hline $\mathrm{O} 2 \mathrm{~W}^{\mathrm{i}}-\mathrm{Na} 1-\mathrm{O}^{\mathrm{i}}$ & $75.79(7)$ & $\mathrm{N} 2-\mathrm{N} 1-\mathrm{H} 1 \mathrm{~N}$ & $122.2(19)$ \\
\hline $\mathrm{O} 2 \mathrm{~W}-\mathrm{Na} 1-\mathrm{O}^{\mathrm{i}}$ & $159.34(8)$ & $\mathrm{C} 4-\mathrm{N} 1-\mathrm{H} 1 \mathrm{~N}$ & $117.8(19)$ \\
\hline $\mathrm{O} 6-\mathrm{Na} 1-\mathrm{O}^{\mathrm{i}}$ & $125.20(8)$ & $\mathrm{N} 1-\mathrm{N} 2-\mathrm{C} 7$ & $120.0(2)$ \\
\hline $\mathrm{O} 1 \mathrm{~W}-\mathrm{Na} 1-\mathrm{Na}{ }^{\mathrm{ii}}$ & $74.68(6)$ & $\mathrm{C} 10-\mathrm{N} 3-\mathrm{H} 3 \mathrm{~N}$ & $123(2)$ \\
\hline $\mathrm{O} 2 \mathrm{~W}^{\mathrm{i}}-\mathrm{Na} 1-\mathrm{Na} 1^{\mathrm{ii}}$ & $127.39(6)$ & $\mathrm{C} 10-\mathrm{N} 3-\mathrm{H} 2 \mathrm{~N}$ & $118(2)$ \\
\hline $\mathrm{O} 2 \mathrm{~W}-\mathrm{Na} 1-\mathrm{Na} 1^{\mathrm{ii}}$ & $40.34(5)$ & $\mathrm{H} 3 \mathrm{~N}-\mathrm{N} 3-\mathrm{H} 2 \mathrm{~N}$ & $120(3)$ \\
\hline
\end{tabular}




\begin{tabular}{|c|c|c|c|}
\hline $\mathrm{O} 6-\mathrm{Na} 1-\mathrm{Na} 1^{\mathrm{ii}}$ & $42.63(5)$ & $\mathrm{C} 2-\mathrm{C} 1-\mathrm{C} 6$ & $120.9(2)$ \\
\hline $\mathrm{O} 6^{\mathrm{i}}-\mathrm{Na} 1-\mathrm{Na} 1^{\mathrm{ii}}$ & $155.75(5)$ & $\mathrm{C} 2-\mathrm{C} 1-\mathrm{S} 1$ & $120.13(18)$ \\
\hline $\mathrm{O} 1 \mathrm{~W}-\mathrm{Na} 1-\mathrm{Na} 1^{\mathrm{i}}$ & $126.43(7)$ & $\mathrm{C} 6-\mathrm{C} 1-\mathrm{S} 1$ & $118.91(18)$ \\
\hline $\mathrm{O} 2 \mathrm{~W}^{\mathrm{i}}-\mathrm{Na} 1-\mathrm{Na} 1^{\mathrm{i}}$ & $41.06(5)$ & $\mathrm{C} 3-\mathrm{C} 2-\mathrm{C} 1$ & $119.5(2)$ \\
\hline $\mathrm{O} 2 \mathrm{~W}-\mathrm{Na} 1-\mathrm{Na} 1^{\mathrm{i}}$ & $135.61(6)$ & $\mathrm{C} 3-\mathrm{C} 2-\mathrm{H} 2$ & 120.2 \\
\hline $\mathrm{O} 6-\mathrm{Na} 1-\mathrm{Na} 1^{\mathrm{i}}$ & $111.93(7)$ & $\mathrm{C} 1-\mathrm{C} 2-\mathrm{H} 2$ & 120.2 \\
\hline $\mathrm{O} 6^{\mathrm{i}}-\mathrm{Na} 1-\mathrm{Na} 1^{\mathrm{i}}$ & $42.29(5)$ & $\mathrm{C} 2-\mathrm{C} 3-\mathrm{C} 4$ & $119.5(2)$ \\
\hline $\mathrm{Na} 1^{\mathrm{ii}}-\mathrm{Na} 1-\mathrm{Na} 1^{\mathrm{i}}$ & $150.73(7)$ & $\mathrm{C} 2-\mathrm{C} 3-\mathrm{H} 3$ & 120.2 \\
\hline $\mathrm{O} 1 \mathrm{~W}-\mathrm{Na} 1-\mathrm{H} 4 \mathrm{~W}$ & $115.1(4)$ & $\mathrm{C} 4-\mathrm{C} 3-\mathrm{H} 3$ & 120.2 \\
\hline $\mathrm{O} 2 \mathrm{~W}^{\mathrm{i}}-\mathrm{Na} 1-\mathrm{H} 4 \mathrm{~W}$ & $79.8(5)$ & $\mathrm{C} 3-\mathrm{C} 4-\mathrm{C} 5$ & $121.4(2)$ \\
\hline $\mathrm{O} 2 \mathrm{~W}-\mathrm{Na} 1-\mathrm{H} 4 \mathrm{~W}$ & $18.8(4)$ & $\mathrm{C} 3-\mathrm{C} 4-\mathrm{N} 1$ & $117.5(2)$ \\
\hline $\mathrm{O} 6-\mathrm{Na} 1-\mathrm{H} 4 \mathrm{~W}$ & $74.0(7)$ & $\mathrm{C} 5-\mathrm{C} 4-\mathrm{N} 1$ & $121.1(2)$ \\
\hline $\mathrm{O} 6{ }^{\mathrm{i}}-\mathrm{Na} 1-\mathrm{H} 4 \mathrm{~W}$ & $154.1(6)$ & $\mathrm{C} 6-\mathrm{C} 5-\mathrm{C} 4$ & $118.7(2)$ \\
\hline $\mathrm{Na} 1^{\mathrm{ii}}-\mathrm{Na} 1-\mathrm{H} 4 \mathrm{~W}$ & $50.1(6)$ & $\mathrm{C} 6-\mathrm{C} 5-\mathrm{H} 5$ & 120.7 \\
\hline $\mathrm{Na} 1^{\mathrm{i}}-\mathrm{Na} 1-\mathrm{H} 4 \mathrm{~W}$ & $118.1(5)$ & $\mathrm{C} 4-\mathrm{C} 5-\mathrm{H} 5$ & 120.7 \\
\hline $\mathrm{O} 2-\mathrm{S} 1-\mathrm{O} 1$ & $113.00(12)$ & $\mathrm{C} 5-\mathrm{C} 6-\mathrm{C} 1$ & $119.9(2)$ \\
\hline $\mathrm{O} 2-\mathrm{S} 1-\mathrm{O} 3$ & $112.05(11)$ & $\mathrm{C} 5-\mathrm{C} 6-\mathrm{H} 6$ & 120.0 \\
\hline $\mathrm{O} 1-\mathrm{S} 1-\mathrm{O} 3$ & $111.19(11)$ & $\mathrm{C} 1-\mathrm{C} 6-\mathrm{H} 6$ & 120.0 \\
\hline $\mathrm{O} 2-\mathrm{S} 1-\mathrm{C} 1$ & $107.81(11)$ & $\mathrm{N} 2-\mathrm{C} 7-\mathrm{C} 8$ & $113.9(2)$ \\
\hline $\mathrm{O} 1-\mathrm{S} 1-\mathrm{C} 1$ & $105.53(11)$ & $\mathrm{N} 2-\mathrm{C} 7-\mathrm{C} 12$ & $127.6(2)$ \\
\hline $\mathrm{O} 3-\mathrm{S} 1-\mathrm{C} 1$ & $106.78(11)$ & $\mathrm{C} 8-\mathrm{C} 7-\mathrm{C} 12$ & $118.6(2)$ \\
\hline $\mathrm{O} 5-\mathrm{S} 2-\mathrm{O} 4$ & $112.19(11)$ & $\mathrm{C} 9-\mathrm{C} 8-\mathrm{C} 7$ & $121.4(2)$ \\
\hline $\mathrm{O} 5-\mathrm{S} 2-\mathrm{O} 6$ & $113.51(11)$ & $\mathrm{C} 9-\mathrm{C} 8-\mathrm{H} 8$ & 119.3 \\
\hline $\mathrm{O} 4-\mathrm{S} 2-\mathrm{O} 6$ & $113.34(11)$ & $\mathrm{C} 7-\mathrm{C} 8-\mathrm{H} 8$ & 119.3 \\
\hline $\mathrm{O} 5-\mathrm{S} 2-\mathrm{C} 9$ & $106.24(11)$ & $\mathrm{C} 8-\mathrm{C} 9-\mathrm{C} 10$ & $120.2(2)$ \\
\hline $\mathrm{O} 4-\mathrm{S} 2-\mathrm{C} 9$ & $105.09(11)$ & $\mathrm{C} 8-\mathrm{C} 9-\mathrm{S} 2$ & $119.96(18)$ \\
\hline $\mathrm{O} 6-\mathrm{S} 2-\mathrm{C} 9$ & $105.60(11)$ & $\mathrm{C} 10-\mathrm{C} 9-\mathrm{S} 2$ & $119.84(17)$ \\
\hline $\mathrm{S} 2-\mathrm{O} 6-\mathrm{Na} 1$ & $130.74(11)$ & $\mathrm{N} 3-\mathrm{C} 10-\mathrm{C} 11$ & $119.2(2)$ \\
\hline $\mathrm{S} 2-\mathrm{O} 6-\mathrm{Na} 1^{\mathrm{ii}}$ & $132.42(11)$ & $\mathrm{N} 3-\mathrm{C} 10-\mathrm{C} 9$ & $122.9(2)$ \\
\hline $\mathrm{Na} 1-\mathrm{O} 6-\mathrm{Na} 1^{\mathrm{ii}}$ & $95.07(6)$ & $\mathrm{C} 11-\mathrm{C} 10-\mathrm{C} 9$ & $117.9(2)$ \\
\hline $\mathrm{Na} 1-\mathrm{O} 1 \mathrm{~W}-\mathrm{H} 2 \mathrm{~W}$ & $110(3)$ & $\mathrm{C} 12-\mathrm{C} 11-\mathrm{C} 10$ & $121.6(2)$ \\
\hline $\mathrm{Na} 1-\mathrm{O} 1 \mathrm{~W}-\mathrm{H} 1 \mathrm{~W}$ & $122(3)$ & $\mathrm{C} 12-\mathrm{C} 11-\mathrm{H} 11$ & 119.2 \\
\hline $\mathrm{H} 2 \mathrm{~W}-\mathrm{O} 1 \mathrm{~W}-\mathrm{H} 1 \mathrm{~W}$ & $99(2)$ & $\mathrm{C} 10-\mathrm{C} 11-\mathrm{H} 11$ & 119.2 \\
\hline $\mathrm{Na} 1^{\mathrm{ii}}-\mathrm{O} 2 \mathrm{~W}-\mathrm{Na} 1$ & $98.59(8)$ & $\mathrm{C} 11-\mathrm{C} 12-\mathrm{C} 7$ & $120.3(2)$ \\
\hline $\mathrm{Na}{ }^{\mathrm{ii}}-\mathrm{O} 2 \mathrm{~W}-\mathrm{H} 3 \mathrm{~W}$ & $121(2)$ & $\mathrm{C} 11-\mathrm{C} 12-\mathrm{H} 12$ & 119.9 \\
\hline $\mathrm{Na} 1-\mathrm{O} 2 \mathrm{~W}-\mathrm{H} 3 \mathrm{~W}$ & $125(2)$ & $\mathrm{C} 7-\mathrm{C} 12-\mathrm{H} 12$ & 119.9 \\
\hline $\mathrm{O} 5-\mathrm{S} 2-\mathrm{O} 6-\mathrm{Na} 1$ & $40.72(16)$ & $\mathrm{C} 2-\mathrm{C} 1-\mathrm{C} 6-\mathrm{C} 5$ & $0.5(4)$ \\
\hline $\mathrm{O} 4-\mathrm{S} 2-\mathrm{O} 6-\mathrm{Na} 1$ & $170.23(12)$ & $\mathrm{S} 1-\mathrm{C} 1-\mathrm{C} 6-\mathrm{C} 5$ & $-178.6(2)$ \\
\hline $\mathrm{C} 9-\mathrm{S} 2-\mathrm{O} 6-\mathrm{Na} 1$ & $-75.26(15)$ & $\mathrm{N} 1-\mathrm{N} 2-\mathrm{C} 7-\mathrm{C} 8$ & $-179.0(2)$ \\
\hline $\mathrm{O} 5-\mathrm{S} 2-\mathrm{O} 6-\mathrm{Na} 1^{\mathrm{ii}}$ & $-120.22(14)$ & $\mathrm{N} 1-\mathrm{N} 2-\mathrm{C} 7-\mathrm{C} 12$ & $0.6(4)$ \\
\hline $\mathrm{O} 4-\mathrm{S} 2-\mathrm{O} 6-\mathrm{Na} 1^{\mathrm{ii}}$ & $9.30(18)$ & $\mathrm{N} 2-\mathrm{C} 7-\mathrm{C} 8-\mathrm{C} 9$ & $179.9(2)$ \\
\hline $\mathrm{C} 9-\mathrm{S} 2-\mathrm{O} 6-\mathrm{Na} 1^{\mathrm{ii}}$ & $123.80(14)$ & $\mathrm{C} 12-\mathrm{C} 7-\mathrm{C} 8-\mathrm{C} 9$ & $0.3(4)$ \\
\hline $\mathrm{C} 4-\mathrm{N} 1-\mathrm{N} 2-\mathrm{C} 7$ & $179.5(2)$ & $\mathrm{C} 7-\mathrm{C} 8-\mathrm{C} 9-\mathrm{C} 10$ & $0.7(4)$ \\
\hline $\mathrm{O} 2-\mathrm{S} 1-\mathrm{C} 1-\mathrm{C} 2$ & $-8.7(2)$ & $\mathrm{C} 7-\mathrm{C} 8-\mathrm{C} 9-\mathrm{S} 2$ & $-178.92(18)$ \\
\hline $\mathrm{O} 1-\mathrm{S} 1-\mathrm{C} 1-\mathrm{C} 2$ & $-129.7(2)$ & $\mathrm{O} 5-\mathrm{S} 2-\mathrm{C} 9-\mathrm{C} 8$ & $-120.0(2)$ \\
\hline $\mathrm{O} 3-\mathrm{S} 1-\mathrm{C} 1-\mathrm{C} 2$ & $111.9(2)$ & $\mathrm{O} 4-\mathrm{S} 2-\mathrm{C} 9-\mathrm{C} 8$ & $120.9(2)$ \\
\hline $\mathrm{O} 2-\mathrm{S} 1-\mathrm{C} 1-\mathrm{C} 6$ & $170.41(19)$ & $\mathrm{O} 6-\mathrm{S} 2-\mathrm{C} 9-\mathrm{C} 8$ & $0.8(2)$ \\
\hline
\end{tabular}




\begin{tabular}{llll}
$\mathrm{O} 1-\mathrm{S} 1-\mathrm{C} 1-\mathrm{C} 6$ & $49.4(2)$ & $\mathrm{O} 5-\mathrm{S} 2-\mathrm{C} 9-\mathrm{C} 10$ & $60.4(2)$ \\
$\mathrm{O} 3-\mathrm{S} 1-\mathrm{C} 1-\mathrm{C} 6$ & $-69.0(2)$ & $\mathrm{O} 4-\mathrm{S} 2-\mathrm{C} 9-\mathrm{C} 10$ & $-58.7(2)$ \\
$\mathrm{C} 6-\mathrm{C} 1-\mathrm{C} 2-\mathrm{C} 3$ & $-0.6(4)$ & $\mathrm{O} 6-\mathrm{S} 2-\mathrm{C} 9-\mathrm{C} 10$ & $-178.80(19)$ \\
$\mathrm{S} 1-\mathrm{C} 1-\mathrm{C} 2-\mathrm{C} 3$ & $178.45(19)$ & $\mathrm{C} 8-\mathrm{C} 9-\mathrm{C} 10-\mathrm{N} 3$ & $178.1(2)$ \\
$\mathrm{C} 1-\mathrm{C} 2-\mathrm{C} 3-\mathrm{C} 4$ & $0.1(4)$ & $\mathrm{S} 2-\mathrm{C} 9-\mathrm{C} 10-\mathrm{N} 3$ & $-2.2(3)$ \\
$\mathrm{C} 2-\mathrm{C} 3-\mathrm{C} 4-\mathrm{C} 5$ & $0.5(4)$ & $\mathrm{C} 8-\mathrm{C} 9-\mathrm{C} 10-\mathrm{C} 11$ & $-1.7(3)$ \\
$\mathrm{C} 2-\mathrm{C} 3-\mathrm{C} 4-\mathrm{N} 1$ & $-178.8(2)$ & $\mathrm{S} 2-\mathrm{C} 9-\mathrm{C} 10-\mathrm{C} 11$ & $177.93(18)$ \\
$\mathrm{N} 2-\mathrm{N} 1-\mathrm{C} 4-\mathrm{C} 3$ & $-166.8(2)$ & $\mathrm{N} 3-\mathrm{C} 10-\mathrm{C} 11-\mathrm{C} 12$ & $-178.1(2)$ \\
$\mathrm{N} 2-\mathrm{N} 1-\mathrm{C} 4-\mathrm{C} 5$ & $13.9(4)$ & $\mathrm{C} 9-\mathrm{C} 10-\mathrm{C} 11-\mathrm{C} 12$ & $1.7(4)$ \\
$\mathrm{C} 3-\mathrm{C} 4-\mathrm{C} 5-\mathrm{C} 6$ & $-0.6(4)$ & $\mathrm{C} 10-\mathrm{C} 11-\mathrm{C} 12-\mathrm{C} 7$ & $-0.8(4)$ \\
$\mathrm{N} 1-\mathrm{C} 4-\mathrm{C} 5-\mathrm{C} 6$ & $178.7(2)$ & $\mathrm{N} 2-\mathrm{C} 7-\mathrm{C} 12-\mathrm{C} 11$ & $-179.8(2)$ \\
$\mathrm{C} 4-\mathrm{C} 5-\mathrm{C} 6-\mathrm{C} 1$ & $0.1(4)$ & $\mathrm{C} 8-\mathrm{C} 7-\mathrm{C} 12-\mathrm{C} 11$ & $-0.3(4)$ \\
\hline
\end{tabular}

Symmetry codes: (i) $x,-y+1 / 2, z+1 / 2$; (ii) $x,-y+1 / 2, z-1 / 2$.

Hydrogen-bond geometry $\left(\AA,{ }^{\circ}\right)$

\begin{tabular}{lllll}
\hline$D-\mathrm{H} \cdots A$ & $D-\mathrm{H}$ & $\mathrm{H} \cdots A$ & $D \cdots A$ & $D-\mathrm{H} \cdots A$ \\
\hline $\mathrm{N} 1-\mathrm{H} 1 N \cdots \mathrm{O} 3 W^{\text {iii }}$ & $0.84(3)$ & $2.10(3)$ & $2.878(3)$ & $153(3)$ \\
$\mathrm{N} 3-\mathrm{H} 2 N \cdots \mathrm{O} 4 W$ & $0.82(3)$ & $2.04(3)$ & $2.847(5)$ & $170(3)$ \\
$\mathrm{N} 3-\mathrm{H} 2 N \cdots \mathrm{O} 5 W$ & $0.82(3)$ & $2.05(4)$ & $2.843(11)$ & $163(3)$ \\
$\mathrm{N} 3-\mathrm{H} 3 N \cdots \mathrm{O} 4$ & $0.81(3)$ & $2.60(3)$ & $3.084(3)$ & $120(3)$ \\
$\mathrm{N} 3-\mathrm{H} 3 N \cdots \mathrm{O} 4^{\mathrm{iv}}$ & $0.81(3)$ & $2.20(3)$ & $2.923(3)$ & $150(3)$ \\
$\mathrm{N} 3-\mathrm{H} 3 N \cdots \mathrm{O} 5$ & $0.81(3)$ & $2.61(3)$ & $3.095(3)$ & $120(3)$ \\
$\mathrm{O} 1 W-\mathrm{H} 1 W \cdots \mathrm{O} 5^{\mathrm{ii}}$ & $0.88(1)$ & $1.93(2)$ & $2.773(3)$ & $160(4)$ \\
$\mathrm{O} 1 W-\mathrm{H} 2 W \cdots \mathrm{O} 4^{\mathrm{i}}$ & $0.88(1)$ & $1.93(2)$ & $2.756(3)$ & $157(4)$ \\
$\mathrm{O} 2 W-\mathrm{H} 3 W \cdots \mathrm{O} 3^{\mathrm{v}}$ & $0.88(1)$ & $1.90(1)$ & $2.774(2)$ & $176(4)$ \\
$\mathrm{O} 2 W-\mathrm{H} 4 W \cdots \mathrm{O} 1^{\mathrm{vi}}$ & $0.88(1)$ & $1.88(1)$ & $2.746(3)$ & $171(3)$ \\
$\mathrm{O} 3 W-\mathrm{H} 5 W \cdots \mathrm{O} 2^{\text {vii }}$ & $0.86(1)$ & $2.03(1)$ & $2.866(3)$ & $164(3)$ \\
$\mathrm{O} 3 W-\mathrm{H} 6 W \cdots \mathrm{O} 3^{\text {vi }}$ & $0.87(1)$ & $2.22(1)$ & $3.081(3)$ & $171(3)$ \\
$\mathrm{O} 4 W-\mathrm{H} 7 W \cdots \mathrm{O} 3^{\mathrm{i}}$ & $0.88(1)$ & $2.02(1)$ & $2.887(5)$ & $175(4)$ \\
$\mathrm{O} 4 W-\mathrm{H} 8 W \cdots \mathrm{O} 1^{\mathrm{ii}}$ & $0.88(1)$ & $1.97(1)$ & $2.846(5)$ & $173(5)$ \\
$\mathrm{O} 5 W-\mathrm{H} 9 W \cdots \mathrm{O} 3^{\mathrm{i}}$ & $0.88(1)$ & $2.08(2)$ & $2.947(13)$ & $170(10)$ \\
$\mathrm{O} 5 W-\mathrm{H} 10 W \cdots \mathrm{O} 1^{\mathrm{ii}}$ & $0.88(1)$ & $1.89(2)$ & $2.765(9)$ & $171(10)$
\end{tabular}

Symmetry codes: (i) $x,-y+1 / 2, z+1 / 2$; (ii) $x,-y+1 / 2, z-1 / 2$; (iii) $x-1, y, z$; (iv) $-x,-y+1,-z$; (v) $-x,-y,-z$; (vi) $-x, y+1 / 2,-z+1 / 2$; (vii) $-x,-y,-z+1$.

Hexaaquamagnesium bis\{2-(4-amino-3-sulfonatophenyl)-1-(4-sulfonatophenyl)diazenium\} octahydrate (IV)

Crystal data

$\left[\mathrm{Mg}\left(\mathrm{H}_{2} \mathrm{O}\right)_{6}\right]\left(\mathrm{C}_{12} \mathrm{H}_{10} \mathrm{~N}_{3} \mathrm{O}_{6} \mathrm{~S}_{2}\right)_{2} \cdot 8 \mathrm{H}_{2} \mathrm{O}$

$M_{r}=989.23$

Monoclinic, $C 2 / c$

$a=36.896(3) \AA$

$b=6.7806(4) \AA$

$c=17.9140(12) \AA$

$\beta=111.178(9)^{\circ}$

$V=4179.0(6) \AA^{3}$

$Z=4$
$F(000)=2072$

$D_{\mathrm{x}}=1.572 \mathrm{Mg} \mathrm{m}^{-3}$

$\mathrm{Cu} K \alpha$ radiation, $\lambda=1.5418 \AA$

Cell parameters from 1905 reflections

$\theta=4.3-73.1^{\circ}$

$\mu=3.12 \mathrm{~mm}^{-1}$

$T=123 \mathrm{~K}$

Long needle, red

$0.5 \times 0.05 \times 0.03 \mathrm{~mm}$ 


\section{Data collection}

Oxford Diffraction Gemini S diffractometer

Radiation source: sealed tube $\omega$ scans

Absorption correction: multi-scan (CrysAlis PRO; Rigaku OD, 2019)

$T_{\min }=0.572, T_{\max }=1.000$

7541 measured reflections

\section{Refinement}

Refinement on $F^{2}$

Least-squares matrix: full

$R\left[F^{2}>2 \sigma\left(F^{2}\right)\right]=0.050$

$w R\left(F^{2}\right)=0.143$

$S=1.06$

4093 reflections

359 parameters

110 restraints
4093 independent reflections 3287 reflections with $I>2 \sigma(I)$

$R_{\text {int }}=0.039$

$\theta_{\text {max }}=73.2^{\circ}, \theta_{\min }=5.0^{\circ}$

$h=-38 \rightarrow 45$

$k=-6 \rightarrow 8$

$l=-21 \rightarrow 15$

Special details

Hydrogen site location: mixed

$\mathrm{H}$ atoms treated by a mixture of independent and constrained refinement

$w=1 /\left[\sigma^{2}\left(F_{\mathrm{o}}^{2}\right)+(0.0813 P)^{2}+0.7784 P\right]$ where $P=\left(F_{\mathrm{o}}^{2}+2 F_{\mathrm{c}}^{2}\right) / 3$

$(\Delta / \sigma)_{\max }<0.001$

$\Delta \rho_{\max }=0.80 \mathrm{e} \AA^{-3}$

$\Delta \rho_{\min }=-0.38$ e $\AA^{-3}$

Geometry. All esds (except the esd in the dihedral angle between two 1.s. planes) are estimated using the full covariance matrix. The cell esds are taken into account individually in the estimation of esds in distances, angles and torsion angles; correlations between esds in cell parameters are only used when they are defined by crystal symmetry. An approximate (isotropic) treatment of cell esds is used for estimating esds involving l.s. planes.

Fractional atomic coordinates and isotropic or equivalent isotropic displacement parameters $\left(\AA^{2}\right)$

\begin{tabular}{|c|c|c|c|c|c|}
\hline & $x$ & $y$ & $z$ & $U_{\text {iso }} * / U_{\text {eq }}$ & Occ. $(<1)$ \\
\hline Mg1 & -0.2500 & 0.2500 & 0.0000 & $0.0176(3)$ & \\
\hline $\mathrm{S} 1$ & $-0.19426(2)$ & $0.24840(8)$ & -0.24675 & $0.01688(17)$ & \\
\hline $\mathrm{O} 1$ & $-0.19535(5)$ & $0.3776(3)$ & $-0.31234(11)$ & $0.0241(4)$ & \\
\hline $\mathrm{O} 2$ & $-0.20622(5)$ & $0.0469(3)$ & $-0.27349(11)$ & $0.0228(4)$ & \\
\hline $\mathrm{O} 3$ & $-0.21518(5)$ & $0.3271(3)$ & $-0.19768(11)$ & $0.0229(4)$ & \\
\hline $\mathrm{O} 1 \mathrm{~W}$ & $-0.24688(6)$ & 0.1251 & $-0.10154(11)$ & $0.0251(4)$ & \\
\hline $\mathrm{O} 2 \mathrm{~W}$ & $-0.27304(6)$ & $0.5014(3)$ & $-0.06023(12)$ & $0.0281(4)$ & \\
\hline $\mathrm{O} 3 \mathrm{~W}$ & $-0.30486(6)$ & $0.1320(3)$ & $-0.02226(12)$ & $0.0246(4)$ & \\
\hline O4W & $-0.31418(6)$ & 0.7439 & $0.00138(13)$ & $0.0266(4)$ & \\
\hline O5W & $-0.29954(6)$ & 0.7674 & $0.16593(12)$ & $0.0236(4)$ & \\
\hline O6W & $-0.39177(7)$ & $0.7067(3)$ & $-0.07645(14)$ & $0.0334(5)$ & \\
\hline O7W & $0.0109(5)$ & $0.219(3)$ & $-0.1575(12)$ & 0.0307 (19) & $0.638(12)$ \\
\hline H13W & $0.0139(17)$ & $0.346(4)$ & $-0.146(4)$ & $0.046^{*}$ & 0.6377 \\
\hline H14W & $0.0355(7)$ & $0.186(8)$ & $-0.144(4)$ & $0.046^{*}$ & 0.6377 \\
\hline N1 & $-0.02640(7)$ & $0.2391(3)$ & $-0.04636(14)$ & $0.0204(5)$ & \\
\hline $\mathrm{N} 2$ & $-0.01425(7)$ & $0.2547(3)$ & $0.03076(14)$ & $0.0213(5)$ & \\
\hline N3 & $0.13859(7)$ & $0.2773(4)$ & $0.22824(16)$ & $0.0233(5)$ & \\
\hline $\mathrm{C} 1$ & $-0.14448(8)$ & 0.2379 & $-0.18386(15)$ & $0.0168(5)$ & \\
\hline $\mathrm{C} 2$ & $-0.13333(8)$ & $0.2471(4)$ & $-0.10121(16)$ & $0.0206(5)$ & \\
\hline $\mathrm{H} 2$ & -0.1524 & 0.2538 & -0.0771 & $0.025^{*}$ & \\
\hline $\mathrm{C} 3$ & $-0.09400(8)$ & $0.2462(4)$ & $-0.05389(16)$ & $0.0214(5)$ & \\
\hline $\mathrm{H} 3$ & -0.0858 & 0.2528 & 0.0028 & $0.026^{*}$ & \\
\hline
\end{tabular}




\begin{tabular}{|c|c|c|c|c|c|}
\hline $\mathrm{C} 4$ & $-0.06672(8)$ & $0.2355(4)$ & $-0.09123(16)$ & $0.0196(5)$ & \\
\hline $\mathrm{C} 5$ & $-0.07798(8)$ & $0.2241(4)$ & $-0.17404(17)$ & $0.0214(5)$ & \\
\hline H5 & -0.0590 & 0.2161 & -0.1982 & $0.026^{*}$ & \\
\hline C6 & $-0.11712(8)$ & $0.2245(4)$ & $-0.22083(16)$ & $0.0213(5)$ & \\
\hline H6 & -0.1253 & 0.2158 & -0.2775 & $0.026^{*}$ & \\
\hline $\mathrm{C} 7$ & $0.02395(8)$ & $0.2602(4)$ & $0.07415(17)$ & $0.0204(5)$ & \\
\hline $\mathrm{C} 8$ & $0.03296(8)$ & $0.2748(4)$ & $0.15798(17)$ & $0.0236(6)$ & \\
\hline H8 & 0.0123 & 0.2806 & 0.1778 & $0.028 *$ & \\
\hline C9 & $0.07028(8)$ & $0.2807(4)$ & $0.21070(16)$ & $0.0213(5)$ & \\
\hline $\mathrm{C} 10$ & $0.10190(8)$ & $0.2726(3)$ & $0.18162(17)$ & $0.0191(5)$ & \\
\hline C11 & $0.09238(8)$ & $0.2577(4)$ & $0.09611(17)$ & $0.0208(5)$ & \\
\hline H11 & 0.1128 & 0.2518 & 0.0758 & $0.025^{*}$ & \\
\hline $\mathrm{C} 12$ & $0.05534(8)$ & $0.2519(4)$ & $0.04459(16)$ & $0.0209(5)$ & \\
\hline H12 & 0.0499 & 0.2424 & -0.0113 & $0.025^{*}$ & \\
\hline $\mathrm{S} 2$ & $0.0782(2)$ & $0.2875(14)$ & $0.3153(3)$ & $0.0256(5)$ & $0.638(12)$ \\
\hline $\mathrm{O} 4$ & $0.0564(3)$ & $0.1246(16)$ & $0.3309(10)$ & $0.0390(19)$ & $0.638(12)$ \\
\hline $\mathrm{O} 5$ & 0.0628 & $0.4763(12)$ & $0.3280(5)$ & $0.0439(16)$ & $0.638(12)$ \\
\hline O6 & $0.11985(18)$ & $0.2653(15)$ & $0.3606(4)$ & $0.0542(18)$ & $0.638(12)$ \\
\hline S2A & $0.0753(4)$ & $0.300(3)$ & $0.3128(5)$ & $0.0256(5)$ & $0.362(12)$ \\
\hline O4A & $0.0650(7)$ & $0.105(3)$ & 0.3300 (19) & 0.0390 (19) & $0.362(12)$ \\
\hline O5A & $0.0488(4)$ & $0.454(2)$ & $0.3169(10)$ & $0.0439(16)$ & $0.362(12)$ \\
\hline O6A & $0.1150(3)$ & $0.362(3)$ & $0.3546(7)$ & $0.0542(18)$ & $0.362(12)$ \\
\hline O8W & $0.0158(10)$ & $0.189(5)$ & $-0.149(2)$ & 0.0307 (19) & $0.362(12)$ \\
\hline H16W & 0.0210 & 0.3101 & -0.1623 & $0.046^{*}$ & $0.362(12)$ \\
\hline H15W & 0.0203 & 0.1197 & -0.1863 & $0.046^{*}$ & $0.362(12)$ \\
\hline $\mathrm{H} 2 \mathrm{~N}$ & $0.1562(12)$ & $0.280(5)$ & $0.207(2)$ & $0.029(9)^{*}$ & \\
\hline $\mathrm{H} 1 \mathrm{~N}$ & $-0.0114(12)$ & $0.226(5)$ & $-0.072(3)$ & $0.034(10)^{*}$ & \\
\hline $\mathrm{H} 3 \mathrm{~N}$ & 0.1447 (14) & $0.299(6)$ & $0.277(3)$ & $0.049(13)^{*}$ & \\
\hline H3W & $-0.2859(8)$ & $0.594(4)$ & $-0.0471(17)$ & $0.024(8)^{*}$ & \\
\hline H1W & $-0.2378(11)$ & $0.172(5)$ & $-0.1364(17)$ & $0.044(11)^{*}$ & \\
\hline H9W & $-0.2895(10)$ & $0.882(3)$ & $0.184(2)$ & $0.043(11)^{*}$ & \\
\hline H8W & $-0.3098(11)$ & $0.729(6)$ & $0.0521(7)$ & $0.051(13)^{*}$ & \\
\hline H11W & $-0.4034(11)$ & $0.606(3)$ & $-0.105(2)$ & $0.052(13)^{*}$ & \\
\hline H7W & -0.3385 (4) & $0.707(5)$ & -0.0197 (19) & $0.033(10)^{*}$ & \\
\hline H5W & $-0.3086(11)$ & $0.0055(18)$ & $-0.021(2)$ & $0.046(11)^{*}$ & \\
\hline H4W & $-0.2777(11)$ & $0.523(6)$ & $-0.1107(9)$ & $0.051(12)^{*}$ & \\
\hline $\mathrm{H} 12 \mathrm{~W}$ & $-0.4031(12)$ & $0.806(4)$ & $-0.106(2)$ & $0.063(15)^{*}$ & \\
\hline H6W & $-0.3258(7)$ & $0.173(5)$ & $-0.0602(19)$ & $0.049(12)^{*}$ & \\
\hline $\mathrm{H} 2 \mathrm{~W}$ & $-0.2649(8)$ & $0.043(4)$ & $-0.1293(18)$ & $0.037(10)^{*}$ & \\
\hline H10W & $-0.2840(9)$ & $0.691(4)$ & $0.2032(18)$ & $0.046(12)^{*}$ & \\
\hline
\end{tabular}

Atomic displacement parameters $\left(\AA^{2}\right)$

\begin{tabular}{lllllll}
\hline & $U^{11}$ & $U^{22}$ & $U^{33}$ & $U^{12}$ & $U^{13}$ & $U^{23}$ \\
\hline $\mathrm{Mg} 1$ & $0.0180(6)$ & $0.0191(5)$ & $0.0148(6)$ & $-0.0012(4)$ & $0.0050(5)$ & $-0.0003(4)$ \\
$\mathrm{S} 1$ & $0.0136(3)$ & $0.0195(3)$ & $0.0170(3)$ & $0.0002(2)$ & $0.0048(2)$ & $0.0011(2)$ \\
O1 & $0.0195(9)$ & $0.0282(9)$ & $0.0237(9)$ & $0.0023(8)$ & $0.0066(7)$ & $0.0069(8)$ \\
O2 & $0.0192(9)$ & $0.0236(9)$ & $0.0221(9)$ & $-0.0023(7)$ & $0.0036(7)$ & $-0.0017(7)$
\end{tabular}




\begin{tabular}{|c|c|c|c|c|c|c|}
\hline $\mathrm{O} 3$ & $0.0194(9)$ & $0.0272(9)$ & $0.0224(9)$ & $0.0016(8)$ & $0.0079(7)$ & $0.0002(7)$ \\
\hline $\mathrm{O} 1 \mathrm{~W}$ & $0.0291(10)$ & $0.0299(10)$ & $0.0183(9)$ & $-0.0098(8)$ & $0.0111(8)$ & $-0.0059(8)$ \\
\hline $\mathrm{O} 2 \mathrm{~W}$ & $0.0354(11)$ & $0.0270(10)$ & $0.0223(9)$ & $0.0094(9)$ & $0.0108(8)$ & $0.0063(8)$ \\
\hline $\mathrm{O} 3 \mathrm{~W}$ & $0.0183(9)$ & $0.0268(9)$ & $0.0254(9)$ & $-0.0036(8)$ & $0.0038(7)$ & $-0.0002(7)$ \\
\hline $\mathrm{O} 4 \mathrm{~W}$ & $0.0221(10)$ & $0.0314(10)$ & $0.0263(10)$ & $-0.0012(8)$ & $0.0088(8)$ & $0.0004(8)$ \\
\hline $\mathrm{O} 5 \mathrm{~W}$ & $0.0195(9)$ & $0.0237(9)$ & $0.0266(10)$ & $0.0000(7)$ & $0.0070(8)$ & $-0.0002(7)$ \\
\hline O6W & $0.0271(11)$ & $0.0371(11)$ & $0.0323(12)$ & $-0.0032(9)$ & $0.0064(9)$ & $-0.0008(9)$ \\
\hline O7W & $0.020(5)$ & $0.042(6)$ & $0.029(4)$ & $0.008(3)$ & $0.008(3)$ & $0.006(3)$ \\
\hline N1 & $0.0168(11)$ & $0.0244(11)$ & $0.0193(11)$ & $0.0004(8)$ & $0.0056(9)$ & $-0.0003(8)$ \\
\hline N2 & $0.0181(11)$ & $0.0248(10)$ & $0.0192(11)$ & $0.0000(8)$ & $0.0048(9)$ & $-0.0001(8)$ \\
\hline N3 & $0.0158(11)$ & $0.0311(12)$ & $0.0223(12)$ & $-0.0035(9)$ & $0.0062(9)$ & $-0.0025(9)$ \\
\hline $\mathrm{C} 1$ & $0.0151(12)$ & $0.0170(10)$ & $0.0167(12)$ & $0.0009(9)$ & $0.0040(9)$ & $0.0020(9)$ \\
\hline $\mathrm{C} 2$ & $0.0178(13)$ & $0.0255(12)$ & $0.0193(13)$ & $0.0012(10)$ & $0.0077(10)$ & $0.0000(9)$ \\
\hline C3 & $0.0185(13)$ & $0.0280(12)$ & $0.0161(12)$ & $-0.0013(10)$ & $0.0042(10)$ & $0.0007(9)$ \\
\hline $\mathrm{C} 4$ & $0.0175(12)$ & $0.0188(11)$ & $0.0211(13)$ & $-0.0007(9)$ & $0.0054(10)$ & $0.0007(9)$ \\
\hline $\mathrm{C} 5$ & $0.0190(13)$ & $0.0239(12)$ & $0.0222(13)$ & $-0.0002(10)$ & $0.0087(11)$ & $0.0013(10)$ \\
\hline C6 & $0.0182(13)$ & $0.0257(12)$ & $0.0193(12)$ & $0.0000(10)$ & $0.0061(10)$ & $0.0003(9)$ \\
\hline $\mathrm{C} 7$ & $0.0178(13)$ & $0.0219(12)$ & $0.0208(13)$ & $-0.0016(10)$ & $0.0062(10)$ & $-0.0008(9)$ \\
\hline $\mathrm{C} 8$ & $0.0168(12)$ & $0.0324(13)$ & $0.0227(13)$ & $-0.0021(11)$ & $0.0086(10)$ & $-0.0028(10)$ \\
\hline C9 & $0.0199(13)$ & $0.0268(13)$ & $0.0185(12)$ & $-0.0026(10)$ & $0.0086(10)$ & $-0.0021(9)$ \\
\hline $\mathrm{C} 10$ & $0.0167(12)$ & $0.0166(11)$ & $0.0244(13)$ & $-0.0013(9)$ & $0.0078(10)$ & $-0.0009(9)$ \\
\hline C11 & $0.0206(13)$ & $0.0201(11)$ & $0.0241(13)$ & $-0.0003(10)$ & $0.0111(11)$ & $0.0005(9)$ \\
\hline $\mathrm{C} 12$ & $0.0217(13)$ & $0.0229(12)$ & $0.0188(12)$ & $-0.0015(10)$ & $0.0080(10)$ & $0.0001(9)$ \\
\hline $\mathrm{S} 2$ & $0.0164(10)$ & $0.0416(12)$ & $0.0181(4)$ & $-0.0034(8)$ & $0.0056(5)$ & $-0.0033(5)$ \\
\hline $\mathrm{O} 4$ & $0.055(5)$ & $0.041(2)$ & $0.0269(12)$ & $-0.002(3)$ & $0.022(4)$ & $0.001(2)$ \\
\hline O5 & $0.067(5)$ & $0.040(2)$ & $0.026(3)$ & $0.002(3)$ & $0.019(4)$ & $-0.0086(17)$ \\
\hline O6 & $0.0169(19)$ & $0.121(6)$ & $0.0188(15)$ & $0.003(3)$ & $-0.0002(14)$ & $0.004(3)$ \\
\hline $\mathrm{S} 2 \mathrm{~A}$ & $0.0164(10)$ & $0.0416(12)$ & $0.0181(4)$ & $-0.0034(8)$ & $0.0056(5)$ & $-0.0033(5)$ \\
\hline $\mathrm{O} 4 \mathrm{~A}$ & $0.055(5)$ & $0.041(2)$ & $0.0269(12)$ & $-0.002(3)$ & $0.022(4)$ & $0.001(2)$ \\
\hline $\mathrm{O} 5 \mathrm{~A}$ & $0.067(5)$ & $0.040(2)$ & $0.026(3)$ & $0.002(3)$ & $0.019(4)$ & $-0.0086(17)$ \\
\hline O6A & $0.0169(19)$ & $0.121(6)$ & $0.0188(15)$ & $0.003(3)$ & $-0.0002(14)$ & $0.004(3)$ \\
\hline $\mathrm{O} 8 \mathrm{~W}$ & $0.020(5)$ & $0.042(6)$ & $0.029(4)$ & $0.008(3)$ & $0.008(3)$ & $0.006(3)$ \\
\hline
\end{tabular}

Geometric parameters $(\AA, \stackrel{\circ}{)})$

\begin{tabular}{llll}
\hline $\mathrm{Mg} 1-\mathrm{O} 2 \mathrm{~W}^{\mathrm{i}}$ & $2.0322(19)$ & $\mathrm{N} 3-\mathrm{H} 3 \mathrm{~N}$ & $0.84(5)$ \\
$\mathrm{Mg} 1-\mathrm{O} 2 \mathrm{~W}$ & $2.0322(19)$ & $\mathrm{C} 1-\mathrm{C} 2$ & $1.388(4)$ \\
$\mathrm{Mg} 1-\mathrm{O} 1 \mathrm{~W}$ & $2.0472(18)$ & $\mathrm{C} 1-\mathrm{C} 6$ & $1.396(4)$ \\
$\mathrm{Mg} 1-\mathrm{O} 1 \mathrm{~W}^{\mathrm{i}}$ & $2.0472(18)$ & $\mathrm{C} 2-\mathrm{C} 3$ & $1.391(4)$ \\
$\mathrm{Mg} 1-\mathrm{O} 3 \mathrm{~W}^{\mathrm{i}}$ & $2.0769(19)$ & $\mathrm{C} 2-\mathrm{H} 2$ & 0.9500 \\
$\mathrm{Mg} 1-\mathrm{O} 3 \mathrm{~W}$ & $2.0769(19)$ & $\mathrm{C} 3-\mathrm{C} 4$ & $1.397(4)$ \\
$\mathrm{S} 1-\mathrm{O} 1$ & $1.4544(19)$ & $\mathrm{C} 3-\mathrm{H} 3$ & 0.9500 \\
$\mathrm{~S} 1-\mathrm{O} 2$ & $1.4624(19)$ & $\mathrm{C} 4-\mathrm{C} 5$ & $1.391(4)$ \\
$\mathrm{S} 1-\mathrm{O} 3$ & $1.464(2)$ & $\mathrm{C} 5-\mathrm{C} 6$ & $1.383(4)$ \\
$\mathrm{S} 1-\mathrm{C} 1$ & $1.776(3)$ & $\mathrm{C} 5-\mathrm{H} 5$ & 0.9500 \\
$\mathrm{O} 1 \mathrm{~W}-\mathrm{H} 1 \mathrm{~W}$ & $0.867(10)$ & $\mathrm{C} 6-\mathrm{H} 6$ & 0.9500 \\
$\mathrm{O} 1 \mathrm{~W}-\mathrm{H} 2 \mathrm{~W}$ & $0.873(10)$ & $\mathrm{C} 7-\mathrm{C} 8$ & $1.419(4)$ \\
$\mathrm{O} 2 \mathrm{~W}-\mathrm{H} 3 \mathrm{~W}$ & $0.868(10)$ & $\mathrm{C} 7-\mathrm{C} 12$ & $1.438(4)$
\end{tabular}




\begin{tabular}{|c|c|c|c|}
\hline $\mathrm{O} 2 \mathrm{~W}-\mathrm{H} 4 \mathrm{~W}$ & $0.869(10)$ & $\mathrm{C} 8-\mathrm{C} 9$ & $1.360(4)$ \\
\hline $\mathrm{O} 3 \mathrm{~W}-\mathrm{H} 5 \mathrm{~W}$ & $0.870(10)$ & $\mathrm{C} 8-\mathrm{H} 8$ & 0.9500 \\
\hline $\mathrm{O} 3 \mathrm{~W}-\mathrm{H} 6 \mathrm{~W}$ & $0.871(10)$ & $\mathrm{C} 9-\mathrm{C} 10$ & $1.441(4)$ \\
\hline $\mathrm{O} 4 \mathrm{~W}-\mathrm{H} 8 \mathrm{~W}$ & $0.870(10)$ & $\mathrm{C} 9-\mathrm{S} 2 \mathrm{~A}$ & $1.775(9)$ \\
\hline $\mathrm{O} 4 \mathrm{~W}-\mathrm{H} 7 \mathrm{~W}$ & $0.874(10)$ & $\mathrm{C} 9-\mathrm{S} 2$ & $1.789(6)$ \\
\hline O5W-H9W & $0.872(10)$ & $\mathrm{C} 10-\mathrm{C} 11$ & $1.446(4)$ \\
\hline $\mathrm{O} 5 \mathrm{~W}-\mathrm{H} 10 \mathrm{~W}$ & $0.874(10)$ & $\mathrm{C} 11-\mathrm{C} 12$ & $1.345(4)$ \\
\hline O6W-H11W & $0.868(10)$ & C11-H11 & 0.9500 \\
\hline $\mathrm{O} 6 \mathrm{~W}-\mathrm{H} 12 \mathrm{~W}$ & $0.871(10)$ & $\mathrm{C} 12-\mathrm{H} 12$ & 0.9500 \\
\hline $\mathrm{O} 7 \mathrm{~W}-\mathrm{H} 13 \mathrm{~W}$ & $0.887(10)$ & $\mathrm{S} 2-\mathrm{O} 5$ & $1.451(6)$ \\
\hline $\mathrm{O} 7 \mathrm{~W}-\mathrm{H} 14 \mathrm{~W}$ & $0.879(10)$ & $\mathrm{S} 2-\mathrm{O} 4$ & $1.452(6)$ \\
\hline $\mathrm{N} 1-\mathrm{N} 2$ & $1.294(4)$ & $\mathrm{S} 2-\mathrm{O} 6$ & $1.465(6)$ \\
\hline $\mathrm{N} 1-\mathrm{C} 4$ & $1.413(3)$ & $\mathrm{S} 2 \mathrm{~A}-\mathrm{O} 4 \mathrm{~A}$ & $1.444(9)$ \\
\hline $\mathrm{N} 1-\mathrm{H} 1 \mathrm{~N}$ & $0.84(4)$ & $\mathrm{S} 2 \mathrm{~A}-\mathrm{O} 5 \mathrm{~A}$ & $1.445(9)$ \\
\hline $\mathrm{N} 2-\mathrm{C} 7$ & $1.342(4)$ & $\mathrm{S} 2 \mathrm{~A}-\mathrm{O} 6 \mathrm{~A}$ & $1.445(9)$ \\
\hline $\mathrm{N} 3-\mathrm{C} 10$ & $1.309(4)$ & O8W-H16W & 0.8927 \\
\hline $\mathrm{N} 3-\mathrm{H} 2 \mathrm{~N}$ & $0.87(4)$ & $\mathrm{O} 8 \mathrm{~W}-\mathrm{H} 15 \mathrm{~W}$ & 0.8807 \\
\hline $\mathrm{O} 2 \mathrm{~W}^{\mathrm{i}}-\mathrm{Mg} 1-\mathrm{O} 2 \mathrm{~W}$ & 180.0 & $\mathrm{C} 3-\mathrm{C} 2-\mathrm{H} 2$ & 120.3 \\
\hline $\mathrm{O} 2 \mathrm{~W}^{\mathrm{i}}-\mathrm{Mg} 1-\mathrm{O} 1 \mathrm{~W}$ & $88.72(8)$ & $\mathrm{C} 2-\mathrm{C} 3-\mathrm{C} 4$ & $118.8(3)$ \\
\hline $\mathrm{O} 2 \mathrm{~W}-\mathrm{Mg} 1-\mathrm{O} 1 \mathrm{~W}$ & $91.28(8)$ & $\mathrm{C} 2-\mathrm{C} 3-\mathrm{H} 3$ & 120.6 \\
\hline $\mathrm{O} 2 \mathrm{~W}^{\mathrm{i}}-\mathrm{Mg} 1-\mathrm{O} 1 \mathrm{~W}^{\mathrm{i}}$ & $91.28(8)$ & $\mathrm{C} 4-\mathrm{C} 3-\mathrm{H} 3$ & 120.6 \\
\hline $\mathrm{O} 2 \mathrm{~W}-\mathrm{Mg} 1-\mathrm{O} 1 \mathrm{~W}^{\mathrm{i}}$ & $88.72(8)$ & $\mathrm{C} 5-\mathrm{C} 4-\mathrm{C} 3$ & $121.6(3)$ \\
\hline $\mathrm{O} 1 \mathrm{~W}-\mathrm{Mg} 1-\mathrm{O} 1 \mathrm{~W}^{\mathrm{i}}$ & 180.0 & $\mathrm{C} 5-\mathrm{C} 4-\mathrm{N} 1$ & $117.1(3)$ \\
\hline $\mathrm{O} 2 \mathrm{~W}^{\mathrm{i}}-\mathrm{Mg} 1-\mathrm{O} 3 \mathrm{~W}^{\mathrm{i}}$ & $91.69(8)$ & $\mathrm{C} 3-\mathrm{C} 4-\mathrm{N} 1$ & $121.3(2)$ \\
\hline $\mathrm{O} 2 \mathrm{~W}-\mathrm{Mg} 1-\mathrm{O} 3 \mathrm{~W}^{\mathrm{i}}$ & $88.31(8)$ & $\mathrm{C} 6-\mathrm{C} 5-\mathrm{C} 4$ & $119.4(3)$ \\
\hline $\mathrm{O} 1 \mathrm{~W}-\mathrm{Mg} 1-\mathrm{O} 3 \mathrm{~W}^{\mathrm{i}}$ & $88.07(8)$ & $\mathrm{C} 6-\mathrm{C} 5-\mathrm{H} 5$ & 120.3 \\
\hline $\mathrm{O} 1 \mathrm{~W}^{\mathrm{i}}-\mathrm{Mg} 1-\mathrm{O} 3 \mathrm{~W}^{\mathrm{i}}$ & $91.93(8)$ & $\mathrm{C} 4-\mathrm{C} 5-\mathrm{H} 5$ & 120.3 \\
\hline $\mathrm{O} 2 \mathrm{~W}^{\mathrm{i}}-\mathrm{Mg} 1-\mathrm{O} 3 \mathrm{~W}$ & $88.31(8)$ & $\mathrm{C} 5-\mathrm{C} 6-\mathrm{C} 1$ & $119.2(3)$ \\
\hline $\mathrm{O} 2 \mathrm{~W}-\mathrm{Mg} 1-\mathrm{O} 3 \mathrm{~W}$ & $91.69(8)$ & $\mathrm{C} 5-\mathrm{C} 6-\mathrm{H} 6$ & 120.4 \\
\hline $\mathrm{O} 1 \mathrm{~W}-\mathrm{Mg} 1-\mathrm{O} 3 \mathrm{~W}$ & $91.93(8)$ & $\mathrm{C} 1-\mathrm{C} 6-\mathrm{H} 6$ & 120.4 \\
\hline $\mathrm{O} 1 \mathrm{~W}^{\mathrm{i}}-\mathrm{Mg} 1-\mathrm{O} 3 \mathrm{~W}$ & $88.07(8)$ & $\mathrm{N} 2-\mathrm{C} 7-\mathrm{C} 8$ & $114.2(2)$ \\
\hline $\mathrm{O} 3 \mathrm{~W}^{\mathrm{i}}-\mathrm{Mg} 1-\mathrm{O} 3 \mathrm{~W}$ & 180.0 & $\mathrm{~N} 2-\mathrm{C} 7-\mathrm{C} 12$ & $127.1(3)$ \\
\hline $\mathrm{O} 1-\mathrm{S} 1-\mathrm{O} 2$ & $112.39(12)$ & $\mathrm{C} 8-\mathrm{C} 7-\mathrm{C} 12$ & $118.7(3)$ \\
\hline $\mathrm{O} 1-\mathrm{S} 1-\mathrm{O} 3$ & $113.50(12)$ & $\mathrm{C} 9-\mathrm{C} 8-\mathrm{C} 7$ & $121.9(3)$ \\
\hline $\mathrm{O} 2-\mathrm{S} 1-\mathrm{O} 3$ & $112.04(12)$ & $\mathrm{C} 9-\mathrm{C} 8-\mathrm{H} 8$ & 119.1 \\
\hline $\mathrm{O} 1-\mathrm{S} 1-\mathrm{C} 1$ & $104.89(11)$ & $\mathrm{C} 7-\mathrm{C} 8-\mathrm{H} 8$ & 119.1 \\
\hline $\mathrm{O} 2-\mathrm{S} 1-\mathrm{C} 1$ & $106.91(11)$ & $\mathrm{C} 8-\mathrm{C} 9-\mathrm{C} 10$ & $119.8(2)$ \\
\hline $\mathrm{O} 3-\mathrm{S} 1-\mathrm{C} 1$ & $106.42(12)$ & $\mathrm{C} 8-\mathrm{C} 9-\mathrm{S} 2 \mathrm{~A}$ & $114.8(5)$ \\
\hline $\mathrm{Mg} 1-\mathrm{O} 1 \mathrm{~W}-\mathrm{H} 1 \mathrm{~W}$ & $130(2)$ & $\mathrm{C} 10-\mathrm{C} 9-\mathrm{S} 2 \mathrm{~A}$ & $125.4(5)$ \\
\hline $\mathrm{Mg} 1-\mathrm{O} 1 \mathrm{~W}-\mathrm{H} 2 \mathrm{~W}$ & $120(2)$ & $\mathrm{C} 8-\mathrm{C} 9-\mathrm{S} 2$ & $117.9(3)$ \\
\hline $\mathrm{H} 1 \mathrm{~W}-\mathrm{O} 1 \mathrm{~W}-\mathrm{H} 2 \mathrm{~W}$ & $104(2)$ & $\mathrm{C} 10-\mathrm{C} 9-\mathrm{S} 2$ & $122.2(3)$ \\
\hline $\mathrm{Mg} 1-\mathrm{O} 2 \mathrm{~W}-\mathrm{H} 3 \mathrm{~W}$ & $129(2)$ & $\mathrm{N} 3-\mathrm{C} 10-\mathrm{C} 9$ & $123.7(3)$ \\
\hline $\mathrm{Mg} 1-\mathrm{O} 2 \mathrm{~W}-\mathrm{H} 4 \mathrm{~W}$ & $125(2)$ & $\mathrm{N} 3-\mathrm{C} 10-\mathrm{C} 11$ & $118.5(3)$ \\
\hline $\mathrm{H} 3 \mathrm{~W}-\mathrm{O} 2 \mathrm{~W}-\mathrm{H} 4 \mathrm{~W}$ & $104(2)$ & $\mathrm{C} 9-\mathrm{C} 10-\mathrm{C} 11$ & $117.8(2)$ \\
\hline $\mathrm{Mg} 1-\mathrm{O} 3 \mathrm{~W}-\mathrm{H} 5 \mathrm{~W}$ & $122(3)$ & $\mathrm{C} 12-\mathrm{C} 11-\mathrm{C} 10$ & $121.8(3)$ \\
\hline $\mathrm{Mg} 1-\mathrm{O} 3 \mathrm{~W}-\mathrm{H} 6 \mathrm{~W}$ & $124(3)$ & $\mathrm{C} 12-\mathrm{C} 11-\mathrm{H} 11$ & 119.1 \\
\hline $\mathrm{H} 5 \mathrm{~W}-\mathrm{O} 3 \mathrm{~W}-\mathrm{H} 6 \mathrm{~W}$ & $103(2)$ & $\mathrm{C} 10-\mathrm{C} 11-\mathrm{H} 11$ & 119.1 \\
\hline
\end{tabular}




\begin{tabular}{|c|c|c|c|}
\hline $\mathrm{H} 8 \mathrm{~W}-\mathrm{O} 4 \mathrm{~W}-\mathrm{H} 7 \mathrm{~W}$ & $101(2)$ & $\mathrm{C} 11-\mathrm{C} 12-\mathrm{C} 7$ & $120.0(3)$ \\
\hline $\mathrm{H} 9 \mathrm{~W}-\mathrm{O} 5 \mathrm{~W}-\mathrm{H} 10 \mathrm{~W}$ & $100(2)$ & $\mathrm{C} 11-\mathrm{C} 12-\mathrm{H} 12$ & 120.0 \\
\hline $\mathrm{H} 11 \mathrm{~W}-\mathrm{O} 6 \mathrm{~W}-\mathrm{H} 12 \mathrm{~W}$ & $103(2)$ & $\mathrm{C} 7-\mathrm{C} 12-\mathrm{H} 12$ & 120.0 \\
\hline $\mathrm{H} 13 \mathrm{~W}-\mathrm{O} 7 \mathrm{~W}-\mathrm{H} 14 \mathrm{~W}$ & $99(2)$ & $\mathrm{O} 5-\mathrm{S} 2-\mathrm{O} 4$ & $111.5(7)$ \\
\hline $\mathrm{N} 2-\mathrm{N} 1-\mathrm{C} 4$ & $119.8(2)$ & $\mathrm{O} 5-\mathrm{S} 2-\mathrm{O} 6$ & $113.3(6)$ \\
\hline $\mathrm{N} 2-\mathrm{N} 1-\mathrm{H} 1 \mathrm{~N}$ & $123(3)$ & $\mathrm{O} 4-\mathrm{S} 2-\mathrm{O} 6$ & $111.0(7)$ \\
\hline $\mathrm{C} 4-\mathrm{N} 1-\mathrm{H} 1 \mathrm{~N}$ & $117(3)$ & $\mathrm{O} 5-\mathrm{S} 2-\mathrm{C} 9$ & $105.2(6)$ \\
\hline $\mathrm{N} 1-\mathrm{N} 2-\mathrm{C} 7$ & $120.5(2)$ & $\mathrm{O} 4-\mathrm{S} 2-\mathrm{C} 9$ & $106.9(8)$ \\
\hline $\mathrm{C} 10-\mathrm{N} 3-\mathrm{H} 2 \mathrm{~N}$ & $119(3)$ & $\mathrm{O} 6-\mathrm{S} 2-\mathrm{C} 9$ & $108.6(5)$ \\
\hline $\mathrm{C} 10-\mathrm{N} 3-\mathrm{H} 3 \mathrm{~N}$ & $120(3)$ & $\mathrm{O} 4 \mathrm{~A}-\mathrm{S} 2 \mathrm{~A}-\mathrm{O} 5 \mathrm{~A}$ & $114.5(14)$ \\
\hline $\mathrm{H} 2 \mathrm{~N}-\mathrm{N} 3-\mathrm{H} 3 \mathrm{~N}$ & $120(4)$ & $\mathrm{O} 4 \mathrm{~A}-\mathrm{S} 2 \mathrm{~A}-\mathrm{O} 6 \mathrm{~A}$ & $116.7(15)$ \\
\hline $\mathrm{C} 2-\mathrm{C} 1-\mathrm{C} 6$ & $121.5(2)$ & $\mathrm{O} 5 \mathrm{~A}-\mathrm{S} 2 \mathrm{~A}-\mathrm{O} 6 \mathrm{~A}$ & $110.1(11)$ \\
\hline $\mathrm{C} 2-\mathrm{C} 1-\mathrm{S} 1$ & $121.0(2)$ & $\mathrm{O} 4 \mathrm{~A}-\mathrm{S} 2 \mathrm{~A}-\mathrm{C} 9$ & $102.3(15)$ \\
\hline $\mathrm{C} 6-\mathrm{C} 1-\mathrm{S} 1$ & $117.5(2)$ & $\mathrm{O} 5 \mathrm{~A}-\mathrm{S} 2 \mathrm{~A}-\mathrm{C} 9$ & $106.6(10)$ \\
\hline $\mathrm{C} 1-\mathrm{C} 2-\mathrm{C} 3$ & $119.4(3)$ & $\mathrm{O} 6 \mathrm{~A}-\mathrm{S} 2 \mathrm{~A}-\mathrm{C} 9$ & $105.3(9)$ \\
\hline $\mathrm{C} 1-\mathrm{C} 2-\mathrm{H} 2$ & 120.3 & $\mathrm{H} 16 \mathrm{~W}-\mathrm{O} 8 \mathrm{~W}-\mathrm{H} 15 \mathrm{~W}$ & 100.0 \\
\hline $\mathrm{C} 4-\mathrm{N} 1-\mathrm{N} 2-\mathrm{C} 7$ & $-179.3(2)$ & $\mathrm{C} 7-\mathrm{C} 8-\mathrm{C} 9-\mathrm{S} 2$ & $-177.1(4)$ \\
\hline $\mathrm{O} 1-\mathrm{S} 1-\mathrm{C} 1-\mathrm{C} 2$ & $137.8(2)$ & $\mathrm{C} 8-\mathrm{C} 9-\mathrm{C} 10-\mathrm{N} 3$ & $-179.9(3)$ \\
\hline $\mathrm{O} 2-\mathrm{S} 1-\mathrm{C} 1-\mathrm{C} 2$ & $-102.7(2)$ & $\mathrm{S} 2 \mathrm{~A}-\mathrm{C} 9-\mathrm{C} 10-\mathrm{N} 3$ & $0.6(8)$ \\
\hline $\mathrm{O} 3-\mathrm{S} 1-\mathrm{C} 1-\mathrm{C} 2$ & $17.3(2)$ & $\mathrm{S} 2-\mathrm{C} 9-\mathrm{C} 10-\mathrm{N} 3$ & $-2.8(5)$ \\
\hline $\mathrm{O} 1-\mathrm{S} 1-\mathrm{C} 1-\mathrm{C} 6$ & $-40.8(2)$ & $\mathrm{C} 8-\mathrm{C} 9-\mathrm{C} 10-\mathrm{C} 11$ & $-0.2(4)$ \\
\hline $\mathrm{O} 2-\mathrm{S} 1-\mathrm{C} 1-\mathrm{C} 6$ & $78.7(2)$ & $\mathrm{S} 2 \mathrm{~A}-\mathrm{C} 9-\mathrm{C} 10-\mathrm{C} 11$ & $-179.6(7)$ \\
\hline $\mathrm{O} 3-\mathrm{S} 1-\mathrm{C} 1-\mathrm{C} 6$ & $-161.37(19)$ & $\mathrm{S} 2-\mathrm{C} 9-\mathrm{C} 10-\mathrm{C} 11$ & $177.0(4)$ \\
\hline $\mathrm{C} 6-\mathrm{C} 1-\mathrm{C} 2-\mathrm{C} 3$ & $1.1(4)$ & $\mathrm{N} 3-\mathrm{C} 10-\mathrm{C} 11-\mathrm{C} 12$ & $180.0(3)$ \\
\hline $\mathrm{S} 1-\mathrm{C} 1-\mathrm{C} 2-\mathrm{C} 3$ & $-177.5(2)$ & $\mathrm{C} 9-\mathrm{C} 10-\mathrm{C} 11-\mathrm{C} 12$ & $0.2(4)$ \\
\hline $\mathrm{C} 1-\mathrm{C} 2-\mathrm{C} 3-\mathrm{C} 4$ & $-0.2(4)$ & $\mathrm{C} 10-\mathrm{C} 11-\mathrm{C} 12-\mathrm{C} 7$ & $-0.1(4)$ \\
\hline $\mathrm{C} 2-\mathrm{C} 3-\mathrm{C} 4-\mathrm{C} 5$ & $-0.5(4)$ & $\mathrm{N} 2-\mathrm{C} 7-\mathrm{C} 12-\mathrm{C} 11$ & $-179.5(3)$ \\
\hline $\mathrm{C} 2-\mathrm{C} 3-\mathrm{C} 4-\mathrm{N} 1$ & $178.4(2)$ & $\mathrm{C} 8-\mathrm{C} 7-\mathrm{C} 12-\mathrm{C} 11$ & $0.1(4)$ \\
\hline $\mathrm{N} 2-\mathrm{N} 1-\mathrm{C} 4-\mathrm{C} 5$ & $178.2(2)$ & $\mathrm{C} 8-\mathrm{C} 9-\mathrm{S} 2-\mathrm{O} 5$ & $-66.3(6)$ \\
\hline $\mathrm{N} 2-\mathrm{N} 1-\mathrm{C} 4-\mathrm{C} 3$ & $-0.8(4)$ & $\mathrm{C} 10-\mathrm{C} 9-\mathrm{S} 2-\mathrm{O} 5$ & $116.5(5)$ \\
\hline $\mathrm{C} 3-\mathrm{C} 4-\mathrm{C} 5-\mathrm{C} 6$ & $0.4(4)$ & $\mathrm{C} 8-\mathrm{C} 9-\mathrm{S} 2-\mathrm{O} 4$ & $52.3(7)$ \\
\hline $\mathrm{N} 1-\mathrm{C} 4-\mathrm{C} 5-\mathrm{C} 6$ & $-178.6(2)$ & $\mathrm{C} 10-\mathrm{C} 9-\mathrm{S} 2-\mathrm{O} 4$ & $-124.9(6)$ \\
\hline $\mathrm{C} 4-\mathrm{C} 5-\mathrm{C} 6-\mathrm{C} 1$ & $0.5(4)$ & $\mathrm{C} 8-\mathrm{C} 9-\mathrm{S} 2-\mathrm{O} 6$ & $172.1(5)$ \\
\hline $\mathrm{C} 2-\mathrm{C} 1-\mathrm{C} 6-\mathrm{C} 5$ & $-1.2(4)$ & $\mathrm{C} 10-\mathrm{C} 9-\mathrm{S} 2-\mathrm{O} 6$ & $-5.1(8)$ \\
\hline $\mathrm{S} 1-\mathrm{C} 1-\mathrm{C} 6-\mathrm{C} 5$ & $177.4(2)$ & $\mathrm{C} 8-\mathrm{C} 9-\mathrm{S} 2 \mathrm{~A}-\mathrm{O} 4 \mathrm{~A}$ & $73.9(12)$ \\
\hline $\mathrm{N} 1-\mathrm{N} 2-\mathrm{C} 7-\mathrm{C} 8$ & $-179.2(2)$ & $\mathrm{C} 10-\mathrm{C} 9-\mathrm{S} 2 \mathrm{~A}-\mathrm{O} 4 \mathrm{~A}$ & $-106.6(11)$ \\
\hline $\mathrm{N} 1-\mathrm{N} 2-\mathrm{C} 7-\mathrm{C} 12$ & $0.5(4)$ & $\mathrm{C} 8-\mathrm{C} 9-\mathrm{S} 2 \mathrm{~A}-\mathrm{O} 5 \mathrm{~A}$ & $-46.7(12)$ \\
\hline $\mathrm{N} 2-\mathrm{C} 7-\mathrm{C} 8-\mathrm{C} 9$ & $179.6(3)$ & $\mathrm{C} 10-\mathrm{C} 9-\mathrm{S} 2 \mathrm{~A}-\mathrm{O} 5 \mathrm{~A}$ & $132.8(9)$ \\
\hline $\mathrm{C} 12-\mathrm{C} 7-\mathrm{C} 8-\mathrm{C} 9$ & $-0.1(4)$ & $\mathrm{C} 8-\mathrm{C} 9-\mathrm{S} 2 \mathrm{~A}-\mathrm{O} 6 \mathrm{~A}$ & $-163.7(9)$ \\
\hline $\mathrm{C} 7-\mathrm{C} 8-\mathrm{C} 9-\mathrm{C} 10$ & $0.1(4)$ & $\mathrm{C} 10-\mathrm{C} 9-\mathrm{S} 2 \mathrm{~A}-\mathrm{O} 6 \mathrm{~A}$ & $15.8(13)$ \\
\hline $\mathrm{C} 7-\mathrm{C} 8-\mathrm{C} 9-\mathrm{S} 2 \mathrm{~A}$ & $179.7(7)$ & & \\
\hline
\end{tabular}

Symmetry code: (i) $-x-1 / 2,-y+1 / 2,-z$.

Hydrogen-bond geometry $\left(A,{ }^{\circ}\right)$

\begin{tabular}{lllll}
\hline$D-\mathrm{H} \cdots A$ & $D-\mathrm{H}$ & $\mathrm{H} \cdots A$ & $D \cdots A$ & $D-\mathrm{H} \cdots A$ \\
\hline $\mathrm{N} 1-\mathrm{H} 1 N \cdots \mathrm{O} 7 W$ & $0.84(4)$ & $1.99(5)$ & $2.80(2)$ & $164(4)$
\end{tabular}




\begin{tabular}{|c|c|c|c|c|}
\hline $\mathrm{N} 1-\mathrm{H} 1 N \cdots \mathrm{O} 8 W$ & $0.84(4)$ & $2.00(6)$ & $2.83(4)$ & $170(4)$ \\
\hline $\mathrm{N} 3-\mathrm{H} 2 N \cdots \mathrm{O} 5 W^{\mathrm{ii}}$ & $0.87(4)$ & $2.02(4)$ & $2.881(3)$ & $174(4)$ \\
\hline $\mathrm{N} 3-\mathrm{H} 3 N \cdots \mathrm{O} 6$ & $0.84(5)$ & $2.03(5)$ & $2.700(7)$ & $137(4)$ \\
\hline $\mathrm{N} 3-\mathrm{H} 3 N \cdots \mathrm{O} 6 A$ & $0.84(5)$ & $2.10(5)$ & $2.763(14)$ & $136(4)$ \\
\hline $\mathrm{O} 1 W-\mathrm{H} 1 W^{\cdots} \cdot \mathrm{O} 3$ & $0.87(1)$ & $1.92(1)$ & $2.769(3)$ & $167(3)$ \\
\hline $\mathrm{O} 1 W-\mathrm{H} 2 W \cdots \mathrm{O} 1^{\mathrm{iii}}$ & $0.87(1)$ & $1.84(1)$ & $2.714(3)$ & $177(4)$ \\
\hline $\mathrm{O} 2 W-\mathrm{H} 3 W \cdots \mathrm{O} 4 W$ & $0.87(1)$ & $1.88(1)$ & $2.727(3)$ & $165(3)$ \\
\hline $\mathrm{O} 2 W-\mathrm{H} 4 W \cdots \mathrm{O} 2^{\mathrm{iv}}$ & $0.87(1)$ & $1.95(1)$ & $2.812(3)$ & $173(4)$ \\
\hline $\mathrm{O} 3 W-\mathrm{H} 5 W^{\cdots} \cdots \mathrm{O} 4 W^{\nu}$ & $0.87(1)$ & $1.85(1)$ & $2.707(3)$ & $169(4)$ \\
\hline $\mathrm{O} 3 W-\mathrm{H} 6 W \cdots \mathrm{O} 6^{\mathrm{vi}}$ & $0.87(1)$ & $2.04(2)$ & $2.897(6)$ & $169(4)$ \\
\hline $\mathrm{O} 3 W-\mathrm{H} 6 W \cdots \mathrm{O} 6 A^{\mathrm{vi}}$ & $0.87(1)$ & $2.18(2)$ & $2.983(11)$ & $153(3)$ \\
\hline $\mathrm{O} 4 W-\mathrm{H} 8 W \cdots \mathrm{O} 5 W$ & $0.87(1)$ & $1.95(2)$ & $2.803(3)$ & $166(4)$ \\
\hline $\mathrm{O} 4 W-\mathrm{H} 7 W \cdots \mathrm{O} 6 W$ & $0.87(1)$ & $1.86(1)$ & $2.706(3)$ & $162(3)$ \\
\hline $\mathrm{O} 5 W-\mathrm{H} 10 W \cdots \mathrm{O} 2^{\mathrm{i}}$ & $0.87(1)$ & $2.16(3)$ & $2.829(3)$ & $133(3)$ \\
\hline $\mathrm{O} 5 W-\mathrm{H} 9 W^{\cdots} \mathrm{O} 3^{\mathrm{vii}}$ & $0.87(1)$ & $1.99(1)$ & $2.820(3)$ & $160(3)$ \\
\hline $\mathrm{O} 5 W-\mathrm{H} 10 W \cdots \mathrm{O} 3^{\text {viii }}$ & $0.87(1)$ & $2.52(3)$ & $3.251(3)$ & $141(3)$ \\
\hline $\mathrm{O} 6 W-\mathrm{H} 11 W^{\cdots} \mathrm{O} 4^{\mathrm{vi}}$ & $0.87(1)$ & $2.17(2)$ & $3.028(13)$ & $167(4)$ \\
\hline $\mathrm{O} 6 W-\mathrm{H} 11 W \cdots \mathrm{O} 4 A^{\mathrm{vi}}$ & $0.87(1)$ & $1.94(3)$ & $2.81(2)$ & $174(4)$ \\
\hline $\mathrm{O} 6 W-\mathrm{H} 12 W \cdots \mathrm{O} 5^{\mathrm{ix}}$ & $0.87(1)$ & $2.02(2)$ & $2.878(8)$ & $170(5)$ \\
\hline $\mathrm{O} 6 W-\mathrm{H} 12 W \cdots \mathrm{O} 5 A^{\mathrm{ix}}$ & $0.87(1)$ & $2.43(2)$ & $3.276(14)$ & $163(4)$ \\
\hline $\mathrm{O} 6 W-\mathrm{H} 12 W \cdots \mathrm{O} 6 A^{\mathrm{ix}}$ & $0.87(1)$ & $2.52(3)$ & $3.220(17)$ & $139(4)$ \\
\hline $\mathrm{O} 7 W-\mathrm{H} 13 W \cdots \mathrm{O} 5^{\mathrm{x}}$ & $0.89(1)$ & $2.35(6)$ & $2.89(2)$ & $119(5)$ \\
\hline $\mathrm{O} 7 W-\mathrm{H} 14 W \cdots \mathrm{O} 6 W^{\mathrm{ii}}$ & $0.88(1)$ & $2.52(3)$ & $3.354(18)$ & $159(5)$ \\
\hline $\mathrm{O} 7 W-\mathrm{H} 14 W \cdots \mathrm{O} 4^{\mathrm{xi}}$ & $0.88(1)$ & $2.35(5)$ & $2.92(2)$ & $123(4)$ \\
\hline $\mathrm{O} 8 W-\mathrm{H} 16 W \cdots \mathrm{O} 5 A^{\mathrm{x}}$ & 0.89 & 2.01 & $2.87(4)$ & 163 \\
\hline $\mathrm{O} 8 W-\mathrm{H} 15 W \cdots \mathrm{O} 4 A^{\mathrm{xi}}$ & 0.88 & 2.18 & $2.81(4)$ & 128 \\
\hline
\end{tabular}

Symmetry codes: (i) $-x-1 / 2,-y+1 / 2,-z$; (ii) $x+1 / 2, y-1 / 2, z$; (iii) $-x-1 / 2, y-1 / 2,-z-1 / 2$; (iv) $-x-1 / 2, y+1 / 2,-z-1 / 2$; (v) $x, y-1, z$; (vi) $x-1 / 2,-y+1 / 2$, $z^{-1 / 2}$; (vii) $-x-1 / 2,-y+3 / 2,-z$; (viii) $x,-y+1, z+1 / 2$; (ix) $x-1 / 2,-y+3 / 2, z-1 / 2$; (x) $x,-y+1, z-1 / 2$; (xi) $x,-y, z-1 / 2$.

Poly $\left[\left[\left\{\mu_{2}\right.\right.\right.$-4-[2-(4-amino-2-methyl-5-methoxyphenyl)diazen-1-yl] benzene-1,3-disulfonato $\}$ di- $\mu$-aqua-

diaquabarium(II)] dihydrate] (V)

Crystal data

$\left[\mathrm{Ba}\left(\mathrm{C}_{14} \mathrm{H}_{13} \mathrm{~N}_{3} \mathrm{O}_{7} \mathrm{~S}_{2}\right)\left(\mathrm{H}_{2} \mathrm{O}\right)_{4}\right] \cdot 2 \mathrm{H}_{2} \mathrm{O}$

$M_{r}=644.83$

Orthorhombic, $\mathrm{Pbca}$

$a=7.1293(4) \AA$

$b=18.8368(11) \AA$

$c=34.752(2) \AA$

$V=4667.0(5) \AA^{3}$

$Z=8$

$F(000)=2576$

$D_{\mathrm{x}}=1.835 \mathrm{Mg} \mathrm{m}^{-3}$

Mo $K \alpha$ radiation, $\lambda=0.71073 \AA$

Cell parameters from 4623 reflections

$\theta=1.0-26.0^{\circ}$

$\mu=1.95 \mathrm{~mm}^{-1}$

$T=123 \mathrm{~K}$

Elongated rhomb, orange

$0.25 \times 0.10 \times 0.04 \mathrm{~mm}$

Data collection

Nonius KappaCCD

diffractometer

Radiation source: rotating anode

$\omega$ and phi scans

Absorption correction: multi-scan

(SADABS; Bruker, 2012)

$T_{\min }=0.448, T_{\max }=0.743$

7914 measured reflections 4489 independent reflections

3554 reflections with $I>2 \sigma(I)$

$R_{\text {int }}=0.037$

$\theta_{\max }=26.0^{\circ}, \theta_{\min }=2.2^{\circ}$ 
$h=-8 \rightarrow 8$

$k=-23 \rightarrow 23$

Refinement

Refinement on $F^{2}$

Least-squares matrix: full

$R\left[F^{2}>2 \sigma\left(F^{2}\right)\right]=0.042$

$w R\left(F^{2}\right)=0.096$

$S=1.15$

4489 reflections

344 parameters

20 restraints $l=-42 \rightarrow 42$

Hydrogen site location: mixed

$\mathrm{H}$ atoms treated by a mixture of independent and constrained refinement

$w=1 /\left[\sigma^{2}\left(F_{\mathrm{o}}^{2}\right)+(0.0229 P)^{2}+26.8527 P\right]$ where $P=\left(F_{\mathrm{o}}{ }^{2}+2 F_{\mathrm{c}}{ }^{2}\right) / 3$

$(\Delta / \sigma)_{\max }<0.001$

$\Delta \rho_{\max }=1.65{\mathrm{e} \AA^{-3}}^{-3}$

$\Delta \rho_{\min }=-1.23$ e $\AA^{-3}$

Special details

Geometry. All esds (except the esd in the dihedral angle between two 1.s. planes) are estimated using the full covariance matrix. The cell esds are taken into account individually in the estimation of esds in distances, angles and torsion angles; correlations between esds in cell parameters are only used when they are defined by crystal symmetry. An approximate (isotropic) treatment of cell esds is used for estimating esds involving 1.s. planes.

Fractional atomic coordinates and isotropic or equivalent isotropic displacement parameters $\left(\AA^{2}\right)$

\begin{tabular}{|c|c|c|c|c|}
\hline & $x$ & $y$ & $z$ & $U_{\text {iso }} * / U_{\text {eq }}$ \\
\hline $\mathrm{Ba} 1$ & $0.46936(4)$ & $0.13398(2)$ & 0.19569 (2) & $0.01523(10)$ \\
\hline $\mathrm{S} 1$ & $0.3700(2)$ & $0.33522(7)$ & 0.17263 (4) & $0.0177(3)$ \\
\hline $\mathrm{S} 2$ & $0.52454(19)$ & $0.61085(6)$ & 0.14177 (4) & $0.0142(3)$ \\
\hline $\mathrm{O} 1$ & $0.4242(6)$ & $0.26422(18)$ & $0.16056(11)$ & $0.0235(9)$ \\
\hline $\mathrm{O} 2$ & $0.1747(6)$ & $0.35234(19)$ & $0.16343(11)$ & $0.0229(9)$ \\
\hline $\mathrm{O} 3$ & $0.4127(6)$ & $0.34897(18)$ & $0.21305(10)$ & $0.0225(9)$ \\
\hline $\mathrm{O} 4$ & $0.3983(5)$ & 0.60937 (18) & $0.17551(10)$ & $0.0178(8)$ \\
\hline $\mathrm{O} 5$ & $0.7040(5)$ & $0.64361(18)$ & $0.15189(10)$ & $0.0174(8)$ \\
\hline O6 & $0.4375(5)$ & $0.64224(18)$ & $0.10819(10)$ & $0.0183(8)$ \\
\hline O7 & $0.9268(6)$ & $0.76192(18)$ & $-0.01184(10)$ & $0.0229(9)$ \\
\hline $\mathrm{O} 1 \mathrm{~W}$ & $0.5033(6)$ & $-0.0101(2)$ & $0.18560(12)$ & $0.0291(10)$ \\
\hline $\mathrm{H} 1 \mathrm{~W}$ & $0.457(8)$ & $-0.042(2)$ & 0.1701 (13) & $0.035^{*}$ \\
\hline $\mathrm{H} 2 \mathrm{~W}$ & $0.569(8)$ & $-0.037(2)$ & $0.2011(13)$ & $0.035^{*}$ \\
\hline $\mathrm{O} 2 \mathrm{~W}$ & $0.4366(6)$ & 0.1078 & $0.11948(12)$ & $0.0328(10)$ \\
\hline H3W & $0.338(5)$ & $0.115(3)$ & 0.1049 (13) & $0.039^{*}$ \\
\hline H4W & $0.510(6)$ & $0.086(3)$ & $0.1030(13)$ & $0.039 *$ \\
\hline $\mathrm{O} 3 \mathrm{~W}$ & $0.6687(6)$ & 0.21189 (19) & $0.25537(11)$ & $0.0227(9)$ \\
\hline H5W & $0.710(7)$ & 0.2458 (19) & $0.2404(13)$ & $0.027 *$ \\
\hline H6W & $0.588(6)$ & $0.236(2)$ & $0.2692(13)$ & $0.027^{*}$ \\
\hline $\mathrm{O} 4 \mathrm{~W}$ & $0.3374(6)$ & $0.0719(2)$ & $0.26436(11)$ & $0.0225(9)$ \\
\hline $\mathrm{H} 7 \mathrm{~W}$ & $0.415(7)$ & $0.072(3)$ & $0.2841(11)$ & $0.027 *$ \\
\hline H8W & $0.320(8)$ & $0.0258(8)$ & $0.2628(14)$ & $0.027 *$ \\
\hline $\mathrm{O} 5 \mathrm{~W}$ & $-0.1119(6)$ & $0.2702(2)$ & $0.19632(11)$ & $0.0238(9)$ \\
\hline H9W & $-0.046(7)$ & $0.305(2)$ & $0.1861(13)$ & $0.029 *$ \\
\hline H10W & $-0.145(8)$ & $0.248(2)$ & $0.1752(8)$ & $0.029 *$ \\
\hline O6W & $0.2298(6)$ & 0.42869 (19) & $0.26713(11)$ & $0.0238(9)$ \\
\hline H11W & $0.274(7)$ & $0.405(2)$ & $0.2472(11)$ & $0.029 *$ \\
\hline H12W & $0.136(6)$ & $0.401(2)$ & $0.2733(15)$ & $0.029 *$ \\
\hline
\end{tabular}




$\begin{array}{lllll}\text { N1 } & 0.7484(6) & 0.5510(2) & 0.07400(12) & 0.0155(9) \\ \text { N2 } & 0.7400(6) & 0.5290(2) & 0.03926(12) & 0.0168(10) \\ \text { N3 } & 0.9314(8) & 0.7070(3) & -0.08174(14) & 0.0250(11) \\ \text { C1 } & 0.5036(7) & 0.3964(3) & 0.14543(14) & 0.0158(11) \\ \text { C2 } & 0.6185(8) & 0.3746(3) & 0.11551(15) & 0.0182(12) \\ \text { H2 } & 0.6392 & 0.3255 & 0.1108 & 0.022^{*} \\ \text { C3 } & 0.7031(8) & 0.4258(3) & 0.09250(15) & 0.0183(12) \\ \text { H3 } & 0.7817 & 0.4113 & 0.0719 & 0.022^{*} \\ \text { C4 } & 0.6745(8) & 0.4981(3) & 0.09918(15) & 0.0158(11) \\ \text { C5 } & 0.5678(8) & 0.5194(3) & 0.13124(15) & 0.0161(11) \\ \text { C6 } & 0.4806(8) & 0.4688(3) & 0.15396(14) & 0.0155(11) \\ \text { H6 } & 0.4055 & 0.4830 & 0.1752 & 0.019^{*} \\ \text { C7 } & 0.7944(7) & 0.5760(3) & 0.01038(14) & 0.0146(11) \\ \text { C8 } & 0.7904(7) & 0.5476(3) & -0.02719(15) & 0.0152(11) \\ \text { C9 } & 0.8361(8) & 0.5924(3) & -0.05756(15) & 0.0175(11) \\ \text { H9 } & 0.8346 & 0.5738 & -0.0830 & 0.021^{*} \\ \text { C10 } & 0.8843(8) & 0.6637(3) & -0.05219(15) & 0.0195(12) \\ \text { C11 } & 0.8853(8) & 0.6905(3) & -0.01369(16) & 0.0182(11) \\ \text { C12 } & 0.8409(7) & 0.6479(3) & 0.01663(15) & 0.0167(11) \\ \text { H12 } & 0.8412 & 0.6666 & 0.0420 & 0.020^{*} \\ \text { C13 } & 0.7344(8) & 0.4715(3) & -0.03471(16) & 0.0202(12) \\ \text { H13A } & 0.7096 & 0.4651 & -0.0622 & 0.030^{*} \\ \text { H13B } & 0.6210 & 0.4602 & -0.0200 & 0.030^{*} \\ \text { H13C } & 0.8364 & 0.4398 & -0.0268 & 0.030^{*} \\ \text { C14 } & 0.9168(9) & 0.7942(3) & 0.02544(16) & 0.0244(13) \\ \text { H14A } & 0.7913 & 0.7869 & 0.0363 & 0.037^{*} \\ \text { H14B } & 0.9418 & 0.8452 & 0.0232 & 0.037^{*} \\ \text { H14C } & 1.0105 & 0.7725 & 0.0424 & 0.037^{*} \\ \text { H1N } & 0.911(9) & 0.693(3) & -0.1055(7) & 0.033(18)^{*} \\ \text { H2N } & 0.955(10) & 0.7519(12) & -0.077(2) & 0.05(2)^{*}\end{array}$

Atomic displacement parameters $\left(\AA^{2}\right)$

\begin{tabular}{lllllll}
\hline & $U^{11}$ & $U^{22}$ & $U^{33}$ & $U^{12}$ & $U^{13}$ & $U^{23}$ \\
\hline Ba1 & $0.01377(17)$ & $0.01302(15)$ & $0.01890(16)$ & $-0.00088(13)$ & $-0.00011(13)$ & $0.00011(12)$ \\
S1 & $0.0207(7)$ & $0.0111(6)$ & $0.0214(7)$ & $-0.0017(5)$ & $0.0025(6)$ & $0.0020(5)$ \\
S2 & $0.0126(6)$ & $0.0110(6)$ & $0.0189(6)$ & $-0.0004(5)$ & $0.0005(5)$ & $0.0001(5)$ \\
O1 & $0.032(2)$ & $0.0110(18)$ & $0.028(2)$ & $0.0017(17)$ & $0.0066(18)$ & $0.0012(15)$ \\
O2 & $0.020(2)$ & $0.0161(19)$ & $0.033(2)$ & $-0.0035(16)$ & $0.0008(17)$ & $0.0027(16)$ \\
O3 & $0.029(2)$ & $0.0173(19)$ & $0.021(2)$ & $-0.0021(17)$ & $0.0030(18)$ & $0.0021(15)$ \\
O4 & $0.0154(19)$ & $0.0146(17)$ & $0.023(2)$ & $0.0081(15)$ & $0.0013(16)$ & $-0.0002(15)$ \\
O5 & $0.015(2)$ & $0.0111(17)$ & $0.026(2)$ & $-0.0021(15)$ & $-0.0007(16)$ & $-0.0024(15)$ \\
O6 & $0.017(2)$ & $0.0131(18)$ & $0.0248(19)$ & $-0.0044(16)$ & $0.0016(16)$ & $0.0037(14)$ \\
O7 & $0.030(2)$ & $0.0142(18)$ & $0.025(2)$ & $-0.0047(17)$ & $0.0030(18)$ & $0.0011(15)$ \\
O1W & $0.033(3)$ & $0.018(2)$ & $0.036(2)$ & $0.0001(19)$ & $-0.010(2)$ & $-0.0025(16)$ \\
O2W & $0.016(2)$ & $0.056(3)$ & $0.026(2)$ & $0.007(2)$ & $-0.0030(18)$ & $-0.015(2)$ \\
O3W & $0.023(2)$ & $0.0203(19)$ & $0.025(2)$ & $-0.0029(18)$ & $0.0034(18)$ & $0.0010(16)$ \\
O4W & $0.025(2)$ & $0.0181(19)$ & $0.024(2)$ & $0.0009(18)$ & $0.0006(18)$ & $0.0034(16)$
\end{tabular}


supporting information

\begin{tabular}{lllllll} 
O5W & $0.025(2)$ & $0.020(2)$ & $0.026(2)$ & $-0.0054(17)$ & $0.003(2)$ & $-0.0012(17)$ \\
O6W & $0.024(2)$ & $0.0178(19)$ & $0.029(2)$ & $-0.0046(18)$ & $0.0048(18)$ & $-0.0031(16)$ \\
N1 & $0.014(2)$ & $0.015(2)$ & $0.018(2)$ & $-0.0014(18)$ & $0.0011(19)$ & $0.0009(17)$ \\
N2 & $0.015(2)$ & $0.016(2)$ & $0.019(2)$ & $-0.0005(19)$ & $-0.0007(19)$ & $0.0003(18)$ \\
N3 & $0.032(3)$ & $0.019(2)$ & $0.024(3)$ & $-0.002(2)$ & $0.002(2)$ & $0.001(2)$ \\
C1 & $0.015(3)$ & $0.013(2)$ & $0.020(3)$ & $-0.001(2)$ & $-0.003(2)$ & $0.003(2)$ \\
C2 & $0.022(3)$ & $0.013(3)$ & $0.020(3)$ & $0.002(2)$ & $0.001(2)$ & $-0.001(2)$ \\
C3 & $0.020(3)$ & $0.016(3)$ & $0.018(3)$ & $0.003(2)$ & $0.003(2)$ & $-0.002(2)$ \\
C4 & $0.015(3)$ & $0.015(3)$ & $0.018(3)$ & $-0.001(2)$ & $0.000(2)$ & $-0.001(2)$ \\
C5 & $0.018(3)$ & $0.011(2)$ & $0.019(3)$ & $-0.003(2)$ & $-0.004(2)$ & $0.0013(19)$ \\
C6 & $0.014(3)$ & $0.017(3)$ & $0.015(2)$ & $-0.002(2)$ & $0.000(2)$ & $-0.0015(19)$ \\
C7 & $0.009(3)$ & $0.018(3)$ & $0.017(3)$ & $0.004(2)$ & $0.001(2)$ & $0.002(2)$ \\
C8 & $0.007(3)$ & $0.016(3)$ & $0.023(3)$ & $0.002(2)$ & $0.001(2)$ & $0.000(2)$ \\
C9 & $0.016(3)$ & $0.018(3)$ & $0.018(3)$ & $0.004(2)$ & $0.001(2)$ & $-0.001(2)$ \\
C10 & $0.013(3)$ & $0.025(3)$ & $0.021(3)$ & $0.001(2)$ & $0.000(2)$ & $0.002(2)$ \\
C11 & $0.016(3)$ & $0.013(2)$ & $0.026(3)$ & $0.002(2)$ & $-0.002(2)$ & $0.001(2)$ \\
C12 & $0.012(3)$ & $0.019(3)$ & $0.019(3)$ & $0.003(2)$ & $-0.002(2)$ & $-0.004(2)$ \\
C13 & $0.019(3)$ & $0.016(3)$ & $0.025(3)$ & $0.001(2)$ & $0.000(2)$ & $-0.002(2)$ \\
C14 & $0.030(4)$ & $0.014(3)$ & $0.029(3)$ & $0.001(2)$ & $0.003(3)$ & $-0.003(2)$ \\
& & & & & & \\
\hline
\end{tabular}

Geometric parameters $\left(A,{ }^{\circ}\right)$

\begin{tabular}{llll}
\hline $\mathrm{Ba} 1-\mathrm{O} 2 \mathrm{~W}$ & $2.704(4)$ & $\mathrm{O} 6 \mathrm{~W}-\mathrm{H} 11 \mathrm{~W}$ & $0.878(10)$ \\
$\mathrm{Ba} 1-\mathrm{O} 1 \mathrm{~W}$ & $2.747(4)$ & $\mathrm{O} 6-\mathrm{H} 12 \mathrm{~W}$ & $0.876(10)$ \\
$\mathrm{Ba} 1-\mathrm{O} 4^{\mathrm{i}}$ & $2.753(4)$ & $\mathrm{N} 1-\mathrm{N} 2$ & $1.277(6)$ \\
$\mathrm{Ba} 1-\mathrm{O} 1$ & $2.759(4)$ & $\mathrm{N} 1-\mathrm{C} 4$ & $1.426(6)$ \\
$\mathrm{Ba} 1-\mathrm{O} 5^{\mathrm{ii}}$ & $2.788(4)$ & $\mathrm{N} 2-\mathrm{C} 7$ & $1.393(6)$ \\
$\mathrm{Ba} 1-\mathrm{O} 4 \mathrm{~W}$ & $2.819(4)$ & $\mathrm{N} 3-\mathrm{C} 10$ & $1.354(7)$ \\
$\mathrm{Ba} 1-\mathrm{O} 3 \mathrm{~W}$ & $2.911(4)$ & $\mathrm{N} 3-\mathrm{H} 1 \mathrm{~N}$ & $0.879(10)$ \\
$\mathrm{Ba} 1-\mathrm{O} 3 \mathrm{~W}^{\mathrm{iii}}$ & $3.105(4)$ & $\mathrm{N} 3-\mathrm{H} 2 \mathrm{~N}$ & $0.877(10)$ \\
$\mathrm{Ba} 1-\mathrm{O} 4 \mathrm{~W}^{\mathrm{iv}}$ & $3.191(4)$ & $\mathrm{C} 1-\mathrm{C} 2$ & $1.386(7)$ \\
$\mathrm{S} 1-\mathrm{O} 1$ & $1.454(4)$ & $\mathrm{C} 1-\mathrm{C} 6$ & $1.406(7)$ \\
$\mathrm{S} 1-\mathrm{O} 3$ & $1.460(4)$ & $\mathrm{C} 2-\mathrm{C} 3$ & $1.391(7)$ \\
$\mathrm{S} 1-\mathrm{O} 2$ & $1.465(4)$ & $\mathrm{C} 2-\mathrm{H} 2$ & 0.9500 \\
$\mathrm{~S} 1-\mathrm{C} 1$ & $1.768(5)$ & $\mathrm{C} 3-\mathrm{C} 4$ & $1.397(7)$ \\
$\mathrm{S} 2-\mathrm{O} 6$ & $1.448(4)$ & $\mathrm{C} 3-\mathrm{H} 3$ & 0.9500 \\
$\mathrm{~S} 2-\mathrm{O} 5$ & $1.463(4)$ & $\mathrm{C} 4-\mathrm{C} 5$ & $1.408(7)$ \\
$\mathrm{S} 2-\mathrm{O} 4$ & $1.478(4)$ & $\mathrm{C} 5-\mathrm{C} 6$ & $1.385(7)$ \\
$\mathrm{S} 2-\mathrm{C} 5$ & $1.788(5)$ & $\mathrm{C} 6-\mathrm{H} 6$ & 0.9500 \\
$\mathrm{O} 4-\mathrm{Ba} 1^{\mathrm{v}}$ & $2.753(4)$ & $\mathrm{C} 7-\mathrm{C} 8$ & $1.411(7)$ \\
$\mathrm{O} 5-\mathrm{Ba} 1^{\mathrm{vi}}$ & $2.788(4)$ & $\mathrm{C} 7-\mathrm{C} 12$ & $1.412(7)$ \\
$\mathrm{O} 7-\mathrm{C} 11$ & $1.379(6)$ & $\mathrm{C} 8-\mathrm{C} 9$ & $1.390(7)$ \\
$\mathrm{O} 7-\mathrm{C} 14$ & $1.433(6)$ & $\mathrm{C} 8-\mathrm{C} 13$ & $1.511(7)$ \\
$\mathrm{O} 1 \mathrm{~W}-\mathrm{H} 1 \mathrm{~W}$ & $0.873(10)$ & $\mathrm{C} 9-\mathrm{C} 10$ & $1.400(7)$ \\
$\mathrm{O} 1 \mathrm{~W}-\mathrm{H} 2 \mathrm{~W}$ & $0.873(10)$ & $\mathrm{C} 9-\mathrm{H} 9$ & 0.9500 \\
$\mathrm{O} 2 \mathrm{~W}-\mathrm{H} 3 \mathrm{~W}$ & $0.877(10)$ & $\mathrm{C} 10-\mathrm{C} 11$ & $1.430(7)$ \\
$\mathrm{O} 2 \mathrm{~W}-\mathrm{H} 4 \mathrm{~W}$ & $0.875(10)$ & $\mathrm{C} 11-\mathrm{C} 12$ & $1.361(7)$ \\
$\mathrm{O} 3 \mathrm{~W}-\mathrm{Ba} 1^{\mathrm{iv}}$ & $3.105(4)$ & $\mathrm{C} 12-\mathrm{H} 12$ & 0.9500 \\
& & &
\end{tabular}




\begin{tabular}{|c|c|c|c|}
\hline $\mathrm{O} 3 \mathrm{~W}-\mathrm{H} 5 \mathrm{~W}$ & $0.875(10)$ & $\mathrm{C} 13-\mathrm{H} 13 \mathrm{~A}$ & 0.9800 \\
\hline $\mathrm{O} 3 \mathrm{~W}-\mathrm{H} 6 \mathrm{~W}$ & $0.876(10)$ & $\mathrm{C} 13-\mathrm{H} 13 \mathrm{~B}$ & 0.9800 \\
\hline $\mathrm{O} 4 \mathrm{~W}-\mathrm{Ba} 1^{\mathrm{iii}}$ & $3.191(4)$ & $\mathrm{C} 13-\mathrm{H} 13 \mathrm{C}$ & 0.9800 \\
\hline $\mathrm{O} 4 \mathrm{~W}-\mathrm{H} 7 \mathrm{~W}$ & $0.879(10)$ & $\mathrm{C} 14-\mathrm{H} 14 \mathrm{~A}$ & 0.9800 \\
\hline $\mathrm{O} 4 \mathrm{~W}-\mathrm{H} 8 \mathrm{~W}$ & $0.878(10)$ & $\mathrm{C} 14-\mathrm{H} 14 \mathrm{~B}$ & 0.9800 \\
\hline O5W-H9W & $0.877(10)$ & $\mathrm{C} 14-\mathrm{H} 14 \mathrm{C}$ & 0.9800 \\
\hline $\mathrm{O} 5 \mathrm{~W}-\mathrm{H} 10 \mathrm{~W}$ & $0.876(10)$ & & \\
\hline $\mathrm{O} 2 \mathrm{~W}-\mathrm{Ba} 1-\mathrm{O} 1 \mathrm{~W}$ & $72.69(14)$ & $\mathrm{H} 5 \mathrm{~W}-\mathrm{O} 3 \mathrm{~W}-\mathrm{H} 6 \mathrm{~W}$ & $100(2)$ \\
\hline $\mathrm{O} 2 \mathrm{~W}-\mathrm{Ba} 1-\mathrm{O} 4^{\mathrm{i}}$ & $68.74(12)$ & $\mathrm{Ba} 1-\mathrm{O} 4 \mathrm{~W}-\mathrm{Ba} 1^{\mathrm{iii}}$ & $119.37(12)$ \\
\hline $\mathrm{O} 1 \mathrm{~W}-\mathrm{Ba} 1-\mathrm{O}^{\mathrm{i}}$ & $83.39(12)$ & $\mathrm{Ba} 1-\mathrm{O} 4 \mathrm{~W}-\mathrm{H} 7 \mathrm{~W}$ & $116(4)$ \\
\hline $\mathrm{O} 2 \mathrm{~W}-\mathrm{Ba} 1-\mathrm{O} 1$ & $73.66(13)$ & 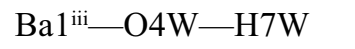 & $100(4)$ \\
\hline $\mathrm{O} 1 \mathrm{~W}-\mathrm{Ba} 1-\mathrm{O} 1$ & $146.32(12)$ & $\mathrm{Ba} 1-\mathrm{O} 4 \mathrm{~W}-\mathrm{H} 8 \mathrm{~W}$ & $114(4)$ \\
\hline $\mathrm{O} 4-\mathrm{Ba} 1-\mathrm{O} 1$ & $85.75(11)$ & 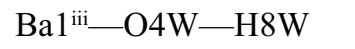 & $106(4)$ \\
\hline $\mathrm{O} 2 \mathrm{~W}-\mathrm{Ba} 1-\mathrm{O} 5^{\mathrm{ii}}$ & $63.22(12)$ & $\mathrm{H} 7 \mathrm{~W}-\mathrm{O} 4 \mathrm{~W}-\mathrm{H} 8 \mathrm{~W}$ & $99(2)$ \\
\hline $\mathrm{O} 1 \mathrm{~W}-\mathrm{Ba} 1-\mathrm{O} 5^{\mathrm{ii}}$ & $85.47(12)$ & $\mathrm{H} 9 \mathrm{~W}-\mathrm{O} 5 \mathrm{~W}-\mathrm{H} 10 \mathrm{~W}$ & $99(2)$ \\
\hline 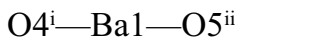 & $131.85(10)$ & $\mathrm{H} 11 \mathrm{~W}-\mathrm{O} 6 \mathrm{~W}-\mathrm{H} 12 \mathrm{~W}$ & $100(2)$ \\
\hline $\mathrm{O} 1-\mathrm{Ba} 1-\mathrm{O}^{\mathrm{ii}}$ & $78.35(11)$ & $\mathrm{N} 2-\mathrm{N} 1-\mathrm{C} 4$ & $109.7(4)$ \\
\hline $\mathrm{O} 2 \mathrm{~W}-\mathrm{Ba} 1-\mathrm{O} 4 \mathrm{~W}$ & $136.43(13)$ & $\mathrm{N} 1-\mathrm{N} 2-\mathrm{C} 7$ & $117.5(4)$ \\
\hline $\mathrm{O} 1 \mathrm{~W}-\mathrm{Ba} 1-\mathrm{O} 4 \mathrm{~W}$ & $74.19(12)$ & $\mathrm{C} 10-\mathrm{N} 3-\mathrm{H} 1 \mathrm{~N}$ & $119(4)$ \\
\hline $\mathrm{O} 4{ }^{\mathrm{i}}-\mathrm{Ba} 1-\mathrm{O} 4 \mathrm{~W}$ & $80.10(11)$ & $\mathrm{C} 10-\mathrm{N} 3-\mathrm{H} 2 \mathrm{~N}$ & $119(5)$ \\
\hline $\mathrm{O} 1-\mathrm{Ba} 1-\mathrm{O} 4 \mathrm{~W}$ & $134.80(11)$ & $\mathrm{H} 1 \mathrm{~N}-\mathrm{N} 3-\mathrm{H} 2 \mathrm{~N}$ & $120(6)$ \\
\hline $\mathrm{O} 5^{\mathrm{ii}}-\mathrm{Ba} 1-\mathrm{O} 4 \mathrm{~W}$ & $140.16(11)$ & $\mathrm{C} 2-\mathrm{C} 1-\mathrm{C} 6$ & $121.0(5)$ \\
\hline $\mathrm{O} 2 \mathrm{~W}-\mathrm{Ba} 1-\mathrm{O} 3 \mathrm{~W}$ & $146.29(13)$ & $\mathrm{C} 2-\mathrm{C} 1-\mathrm{S} 1$ & $121.8(4)$ \\
\hline $\mathrm{O} 1 \mathrm{~W}-\mathrm{Ba} 1-\mathrm{O} 3 \mathrm{~W}$ & $123.10(12)$ & $\mathrm{C} 6-\mathrm{C} 1-\mathrm{S} 1$ & $117.2(4)$ \\
\hline $\mathrm{O} 4 \mathrm{i}-\mathrm{Ba} 1-\mathrm{O} 3 \mathrm{~W}$ & $136.99(11)$ & $\mathrm{C} 1-\mathrm{C} 2-\mathrm{C} 3$ & $118.8(5)$ \\
\hline $\mathrm{O} 1-\mathrm{Ba} 1-\mathrm{O} 3 \mathrm{~W}$ & $85.63(11)$ & $\mathrm{C} 1-\mathrm{C} 2-\mathrm{H} 2$ & 120.6 \\
\hline $\mathrm{O} 5^{\mathrm{ii}}-\mathrm{Ba} 1-\mathrm{O} 3 \mathrm{~W}$ & $87.04(11)$ & $\mathrm{C} 3-\mathrm{C} 2-\mathrm{H} 2$ & 120.6 \\
\hline $\mathrm{O} 4 \mathrm{~W}-\mathrm{Ba} 1-\mathrm{O} 3 \mathrm{~W}$ & $76.65(11)$ & $\mathrm{C} 2-\mathrm{C} 3-\mathrm{C} 4$ & $121.2(5)$ \\
\hline $\mathrm{O} 2 \mathrm{~W}-\mathrm{Ba} 1-\mathrm{O} 3 \mathrm{~W}^{\mathrm{iii}}$ & $124.26(12)$ & $\mathrm{C} 2-\mathrm{C} 3-\mathrm{H} 3$ & 119.4 \\
\hline $\mathrm{O} 1 \mathrm{~W}-\mathrm{Ba} 1-\mathrm{O} 3 \mathrm{~W}^{\mathrm{iii}}$ & $126.70(12)$ & $\mathrm{C} 4-\mathrm{C} 3-\mathrm{H} 3$ & 119.4 \\
\hline $\mathrm{O} 4^{\mathrm{i}}-\mathrm{Ba} 1-\mathrm{O} 3 \mathrm{~W}^{\mathrm{iii}}$ & $64.01(10)$ & $\mathrm{C} 3-\mathrm{C} 4-\mathrm{C} 5$ & $119.2(5)$ \\
\hline $\mathrm{O} 1-\mathrm{Ba} 1-\mathrm{O} 3 \mathrm{~W}^{\mathrm{iii}}$ & $75.02(10)$ & $\mathrm{C} 3-\mathrm{C} 4-\mathrm{N} 1$ & $121.7(5)$ \\
\hline $\mathrm{O} 5^{\mathrm{ii}}-\mathrm{Ba} 1-\mathrm{O} 3 \mathrm{~W}^{\mathrm{iii}}$ & $147.67(10)$ & $\mathrm{C} 5-\mathrm{C} 4-\mathrm{N} 1$ & $119.1(4)$ \\
\hline $\mathrm{O} 4 \mathrm{~W}-\mathrm{Ba} 1-\mathrm{O} 3 \mathrm{~W}^{\mathrm{iii}}$ & $60.15(10)$ & $\mathrm{C} 6-\mathrm{C} 5-\mathrm{C} 4$ & $119.9(5)$ \\
\hline $\mathrm{O} 3 \mathrm{~W}-\mathrm{Ba} 1-\mathrm{O} 3 \mathrm{~W}^{\mathrm{iii}}$ & $73.06(5)$ & $\mathrm{C} 6-\mathrm{C} 5-\mathrm{S} 2$ & $118.0(4)$ \\
\hline $\mathrm{O} 2 \mathrm{~W}-\mathrm{Ba} 1-\mathrm{O} 4 \mathrm{~W}^{\mathrm{iv}}$ & $115.49(11)$ & $\mathrm{C} 4-\mathrm{C} 5-\mathrm{S} 2$ & $122.0(4)$ \\
\hline $\mathrm{O} 1 \mathrm{~W}-\mathrm{Ba} 1-\mathrm{O} 4 \mathrm{~W}^{\mathrm{iv}}$ & $67.73(11)$ & $\mathrm{C} 5-\mathrm{C} 6-\mathrm{C} 1$ & $119.7(5)$ \\
\hline $\mathrm{O} 4-\mathrm{Ba} 1-\mathrm{O} 4 \mathrm{~W}^{\mathrm{iv}}$ & $146.32(10)$ & $\mathrm{C} 5-\mathrm{C} 6-\mathrm{H} 6$ & 120.2 \\
\hline $\mathrm{O} 1-\mathrm{Ba} 1-\mathrm{O} 4 \mathrm{~W}^{\mathrm{iv}}$ & $127.91(11)$ & $\mathrm{C} 1-\mathrm{C} 6-\mathrm{H} 6$ & 120.2 \\
\hline $\mathrm{O} 5^{\mathrm{ii}}-\mathrm{Ba} 1-\mathrm{O} 4 \mathrm{~W}^{\mathrm{iv}}$ & $64.82(10)$ & $\mathrm{N} 2-\mathrm{C} 7-\mathrm{C} 8$ & $114.9(4)$ \\
\hline $\mathrm{O} 4 \mathrm{~W}-\mathrm{Ba} 1-\mathrm{O} 4 \mathrm{~W}^{\mathrm{iv}}$ & $75.76(7)$ & $\mathrm{N} 2-\mathrm{C} 7-\mathrm{C} 12$ & $124.3(5)$ \\
\hline $\mathrm{O} 3 \mathrm{~W}-\mathrm{Ba} 1-\mathrm{O} 4 \mathrm{~W}^{\mathrm{iv}}$ & $58.23(10)$ & $\mathrm{C} 8-\mathrm{C} 7-\mathrm{C} 12$ & $120.7(5)$ \\
\hline $\mathrm{O} 3 \mathrm{~W}^{\mathrm{iii}}-\mathrm{Ba} 1-\mathrm{O} 4 \mathrm{~W}^{\mathrm{iv}}$ & $120.18(10)$ & $\mathrm{C} 9-\mathrm{C} 8-\mathrm{C} 7$ & $117.9(5)$ \\
\hline $\mathrm{O} 1-\mathrm{S} 1-\mathrm{O} 3$ & $112.7(2)$ & $\mathrm{C} 9-\mathrm{C} 8-\mathrm{C} 13$ & $120.4(5)$ \\
\hline $\mathrm{O} 1-\mathrm{S} 1-\mathrm{O} 2$ & $113.1(2)$ & $\mathrm{C} 7-\mathrm{C} 8-\mathrm{C} 13$ & $121.6(5)$ \\
\hline $\mathrm{O} 3-\mathrm{S} 1-\mathrm{O} 2$ & $111.7(2)$ & $\mathrm{C} 8-\mathrm{C} 9-\mathrm{C} 10$ & $122.6(5)$ \\
\hline $\mathrm{O} 1-\mathrm{S} 1-\mathrm{C} 1$ & $107.6(2)$ & $\mathrm{C} 8-\mathrm{C} 9-\mathrm{H} 9$ & 118.7 \\
\hline
\end{tabular}




\begin{tabular}{|c|c|c|c|}
\hline $\mathrm{O} 3-\mathrm{S} 1-\mathrm{C} 1$ & $106.7(2)$ & $\mathrm{C} 10-\mathrm{C} 9-\mathrm{H} 9$ & 118.7 \\
\hline $\mathrm{O} 2-\mathrm{S} 1-\mathrm{C} 1$ & $104.6(2)$ & $\mathrm{N} 3-\mathrm{C} 10-\mathrm{C} 9$ & $122.6(5)$ \\
\hline $\mathrm{O} 6-\mathrm{S} 2-\mathrm{O} 5$ & $113.3(2)$ & $\mathrm{N} 3-\mathrm{C} 10-\mathrm{C} 11$ & $119.7(5)$ \\
\hline $\mathrm{O} 6-\mathrm{S} 2-\mathrm{O} 4$ & $112.7(2)$ & $\mathrm{C} 9-\mathrm{C} 10-\mathrm{C} 11$ & $117.7(5)$ \\
\hline $\mathrm{O} 5-\mathrm{S} 2-\mathrm{O} 4$ & $110.5(2)$ & $\mathrm{C} 12-\mathrm{C} 11-\mathrm{O} 7$ & $126.0(5)$ \\
\hline $\mathrm{O} 6-\mathrm{S} 2-\mathrm{C} 5$ & $107.6(2)$ & $\mathrm{C} 12-\mathrm{C} 11-\mathrm{C} 10$ & $121.0(5)$ \\
\hline $\mathrm{O} 5-\mathrm{S} 2-\mathrm{C} 5$ & $107.7(2)$ & $\mathrm{O} 7-\mathrm{C} 11-\mathrm{C} 10$ & $112.9(4)$ \\
\hline $\mathrm{O} 4-\mathrm{S} 2-\mathrm{C} 5$ & $104.4(2)$ & $\mathrm{C} 11-\mathrm{C} 12-\mathrm{C} 7$ & $120.1(5)$ \\
\hline $\mathrm{S} 1-\mathrm{O} 1-\mathrm{Ba} 1$ & $136.2(2)$ & $\mathrm{C} 11-\mathrm{C} 12-\mathrm{H} 12$ & 120.0 \\
\hline $\mathrm{S} 2-\mathrm{O} 4-\mathrm{Ba}^{\mathrm{v}}$ & $141.1(2)$ & $\mathrm{C} 7-\mathrm{C} 12-\mathrm{H} 12$ & 120.0 \\
\hline $\mathrm{S} 2-\mathrm{O} 5-\mathrm{Ba} 1^{\mathrm{vi}}$ & $146.5(2)$ & $\mathrm{C} 8-\mathrm{C} 13-\mathrm{H} 13 \mathrm{~A}$ & 109.5 \\
\hline $\mathrm{C} 11-\mathrm{O} 7-\mathrm{C} 14$ & $116.4(4)$ & $\mathrm{C} 8-\mathrm{C} 13-\mathrm{H} 13 \mathrm{~B}$ & 109.5 \\
\hline $\mathrm{Ba} 1-\mathrm{O} 1 \mathrm{~W}-\mathrm{H} 1 \mathrm{~W}$ & $137(3)$ & $\mathrm{H} 13 \mathrm{~A}-\mathrm{C} 13-\mathrm{H} 13 \mathrm{~B}$ & 109.5 \\
\hline $\mathrm{Ba} 1-\mathrm{O} 1 \mathrm{~W}-\mathrm{H} 2 \mathrm{~W}$ & $123(3)$ & $\mathrm{C} 8-\mathrm{C} 13-\mathrm{H} 13 \mathrm{C}$ & 109.5 \\
\hline $\mathrm{H} 1 \mathrm{~W}-\mathrm{O} 1 \mathrm{~W}-\mathrm{H} 2 \mathrm{~W}$ & $101(2)$ & $\mathrm{H} 13 \mathrm{~A}-\mathrm{C} 13-\mathrm{H} 13 \mathrm{C}$ & 109.5 \\
\hline $\mathrm{Ba} 1-\mathrm{O} 2 \mathrm{~W}-\mathrm{H} 3 \mathrm{~W}$ & $127(4)$ & $\mathrm{H} 13 \mathrm{~B}-\mathrm{C} 13-\mathrm{H} 13 \mathrm{C}$ & 109.5 \\
\hline $\mathrm{Ba} 1-\mathrm{O} 2 \mathrm{~W}-\mathrm{H} 4 \mathrm{~W}$ & $132(4)$ & $\mathrm{O} 7-\mathrm{C} 14-\mathrm{H} 14 \mathrm{~A}$ & 109.5 \\
\hline $\mathrm{H} 3 \mathrm{~W}-\mathrm{O} 2 \mathrm{~W}-\mathrm{H} 4 \mathrm{~W}$ & $100(2)$ & $\mathrm{O} 7-\mathrm{C} 14-\mathrm{H} 14 \mathrm{~B}$ & 109.5 \\
\hline $\mathrm{Ba} 1-\mathrm{O} 3 \mathrm{~W}-\mathrm{Ba}^{\mathrm{iv}}$ & $119.27(12)$ & $\mathrm{H} 14 \mathrm{~A}-\mathrm{C} 14-\mathrm{H} 14 \mathrm{~B}$ & 109.5 \\
\hline $\mathrm{Ba} 1-\mathrm{O} 3 \mathrm{~W}-\mathrm{H} 5 \mathrm{~W}$ & $96(4)$ & $\mathrm{O} 7-\mathrm{C} 14-\mathrm{H} 14 \mathrm{C}$ & 109.5 \\
\hline $\mathrm{Ba} 1^{\mathrm{iv}}-\mathrm{O} 3 \mathrm{~W}-\mathrm{H} 5 \mathrm{~W}$ & $116(4)$ & $\mathrm{H} 14 \mathrm{~A}-\mathrm{C} 14-\mathrm{H} 14 \mathrm{C}$ & 109.5 \\
\hline $\mathrm{Ba} 1-\mathrm{O} 3 \mathrm{~W}-\mathrm{H} 6 \mathrm{~W}$ & $109(4)$ & $\mathrm{H} 14 \mathrm{~B}-\mathrm{C} 14-\mathrm{H} 14 \mathrm{C}$ & 109.5 \\
\hline $\mathrm{Ba}^{\mathrm{iv}}-\mathrm{O} 3 \mathrm{~W}-\mathrm{H} 6 \mathrm{~W}$ & $114(4)$ & & \\
\hline $\mathrm{O} 3-\mathrm{S} 1-\mathrm{O} 1-\mathrm{Ba} 1$ & $26.9(4)$ & $\mathrm{O} 4-\mathrm{S} 2-\mathrm{C} 5-\mathrm{C} 6$ & $1.2(5)$ \\
\hline $\mathrm{O} 2-\mathrm{S} 1-\mathrm{O} 1-\mathrm{Ba} 1$ & $-100.9(3)$ & $\mathrm{O} 6-\mathrm{S} 2-\mathrm{C} 5-\mathrm{C} 4$ & $56.1(5)$ \\
\hline $\mathrm{C} 1-\mathrm{S} 1-\mathrm{O} 1-\mathrm{Ba} 1$ & $144.1(3)$ & $\mathrm{O} 5-\mathrm{S} 2-\mathrm{C} 5-\mathrm{C} 4$ & $-66.4(5)$ \\
\hline $\mathrm{O} 6-\mathrm{S} 2-\mathrm{O} 4-\mathrm{Ba}^{\mathrm{v}}$ & $8.8(4)$ & $\mathrm{O} 4-\mathrm{S} 2-\mathrm{C} 5-\mathrm{C} 4$ & $176.1(4)$ \\
\hline $\mathrm{O} 5-\mathrm{S} 2-\mathrm{O} 4-\mathrm{Ba}^{\mathrm{v}}$ & $136.7(3)$ & $\mathrm{C} 4-\mathrm{C} 5-\mathrm{C} 6-\mathrm{C} 1$ & $1.8(8)$ \\
\hline $\mathrm{C} 5-\mathrm{S} 2-\mathrm{O} 4-\mathrm{Ba}^{\mathrm{v}}$ & $-107.7(3)$ & $\mathrm{S} 2-\mathrm{C} 5-\mathrm{C} 6-\mathrm{C} 1$ & $176.9(4)$ \\
\hline $\mathrm{O} 6-\mathrm{S} 2-\mathrm{O} 5-\mathrm{Ba}^{\mathrm{vi}}$ & $-167.3(3)$ & $\mathrm{C} 2-\mathrm{C} 1-\mathrm{C} 6-\mathrm{C} 5$ & $2.6(8)$ \\
\hline $\mathrm{O} 4-\mathrm{S} 2-\mathrm{O} 5-\mathrm{Ba} 1^{\mathrm{vi}}$ & $65.1(4)$ & $\mathrm{S} 1-\mathrm{C} 1-\mathrm{C} 6-\mathrm{C} 5$ & $-173.9(4)$ \\
\hline $\mathrm{C} 5-\mathrm{S} 2-\mathrm{O} 5-\mathrm{Ba} 1^{\mathrm{vi}}$ & $-48.3(4)$ & $\mathrm{N} 1-\mathrm{N} 2-\mathrm{C} 7-\mathrm{C} 8$ & $177.2(5)$ \\
\hline $\mathrm{C} 4-\mathrm{N} 1-\mathrm{N} 2-\mathrm{C} 7$ & $175.6(4)$ & $\mathrm{N} 1-\mathrm{N} 2-\mathrm{C} 7-\mathrm{C} 12$ & $-6.2(8)$ \\
\hline $\mathrm{O} 1-\mathrm{S} 1-\mathrm{C} 1-\mathrm{C} 2$ & $6.8(5)$ & $\mathrm{N} 2-\mathrm{C} 7-\mathrm{C} 8-\mathrm{C} 9$ & $177.6(5)$ \\
\hline $\mathrm{O} 3-\mathrm{S} 1-\mathrm{C} 1-\mathrm{C} 2$ & $127.9(4)$ & $\mathrm{C} 12-\mathrm{C} 7-\mathrm{C} 8-\mathrm{C} 9$ & $0.9(8)$ \\
\hline $\mathrm{O} 2-\mathrm{S} 1-\mathrm{C} 1-\mathrm{C} 2$ & $-113.7(5)$ & $\mathrm{N} 2-\mathrm{C} 7-\mathrm{C} 8-\mathrm{C} 13$ & $-1.1(7)$ \\
\hline $\mathrm{O} 1-\mathrm{S} 1-\mathrm{C} 1-\mathrm{C} 6$ & $-176.7(4)$ & $\mathrm{C} 12-\mathrm{C} 7-\mathrm{C} 8-\mathrm{C} 13$ & $-177.8(5)$ \\
\hline $\mathrm{O} 3-\mathrm{S} 1-\mathrm{C} 1-\mathrm{C} 6$ & $-55.6(5)$ & $\mathrm{C} 7-\mathrm{C} 8-\mathrm{C} 9-\mathrm{C} 10$ & $-0.4(8)$ \\
\hline $\mathrm{O} 2-\mathrm{S} 1-\mathrm{C} 1-\mathrm{C} 6$ & $62.8(4)$ & $\mathrm{C} 13-\mathrm{C} 8-\mathrm{C} 9-\mathrm{C} 10$ & $178.4(5)$ \\
\hline $\mathrm{C} 6-\mathrm{C} 1-\mathrm{C} 2-\mathrm{C} 3$ & $-3.6(8)$ & $\mathrm{C} 8-\mathrm{C} 9-\mathrm{C} 10-\mathrm{N} 3$ & $179.0(5)$ \\
\hline $\mathrm{S} 1-\mathrm{C} 1-\mathrm{C} 2-\mathrm{C} 3$ & $172.8(4)$ & $\mathrm{C} 8-\mathrm{C} 9-\mathrm{C} 10-\mathrm{C} 11$ & $-0.1(8)$ \\
\hline $\mathrm{C} 1-\mathrm{C} 2-\mathrm{C} 3-\mathrm{C} 4$ & $0.3(8)$ & $\mathrm{C} 14-\mathrm{O} 7-\mathrm{C} 11-\mathrm{C} 12$ & $-1.8(8)$ \\
\hline $\mathrm{C} 2-\mathrm{C} 3-\mathrm{C} 4-\mathrm{C} 5$ & $4.0(8)$ & $\mathrm{C} 14-\mathrm{O} 7-\mathrm{C} 11-\mathrm{C} 10$ & $175.4(5)$ \\
\hline $\mathrm{C} 2-\mathrm{C} 3-\mathrm{C} 4-\mathrm{N} 1$ & $-175.0(5)$ & $\mathrm{N} 3-\mathrm{C} 10-\mathrm{C} 11-\mathrm{C} 12$ & $-179.2(5)$ \\
\hline $\mathrm{N} 2-\mathrm{N} 1-\mathrm{C} 4-\mathrm{C} 3$ & $36.7(7)$ & $\mathrm{C} 9-\mathrm{C} 10-\mathrm{C} 11-\mathrm{C} 12$ & $0.0(8)$ \\
\hline $\mathrm{N} 2-\mathrm{N} 1-\mathrm{C} 4-\mathrm{C} 5$ & $-142.4(5)$ & $\mathrm{N} 3-\mathrm{C} 10-\mathrm{C} 11-\mathrm{O} 7$ & $3.4(8)$ \\
\hline $\mathrm{C} 3-\mathrm{C} 4-\mathrm{C} 5-\mathrm{C} 6$ & $-5.0(8)$ & $\mathrm{C} 9-\mathrm{C} 10-\mathrm{C} 11-\mathrm{O} 7$ & $-177.4(5)$ \\
\hline
\end{tabular}




$\begin{array}{llll}\mathrm{N} 1-\mathrm{C} 4-\mathrm{C} 5-\mathrm{C} 6 & 174.0(5) & \mathrm{O} 7-\mathrm{C} 11-\mathrm{C} 12-\mathrm{C} 7 & 177.6(5) \\ \mathrm{C} 3-\mathrm{C} 4-\mathrm{C} 5-\mathrm{S} 2 & -179.9(4) & \mathrm{C} 10-\mathrm{C} 11-\mathrm{C} 12-\mathrm{C} 7 & 0.5(8) \\ \mathrm{N} 1-\mathrm{C} 4-\mathrm{C} 5-\mathrm{S} 2 & -0.8(7) & \mathrm{N} 2-\mathrm{C} 7-\mathrm{C} 12-\mathrm{C} 11 & -177.4(5) \\ \mathrm{O} 6-\mathrm{S} 2-\mathrm{C} 5-\mathrm{C} 6 & -118.8(4) & \mathrm{C} 8-\mathrm{C} 7-\mathrm{C} 12-\mathrm{C} 11 & -1.0(8) \\ \mathrm{O} 5-\mathrm{S} 2-\mathrm{C} 5-\mathrm{C} 6 & 118.6(4) & & \end{array}$

Symmetry codes: (i) $-x+1 / 2, y-1 / 2, z$; (ii) $-x+3 / 2, y-1 / 2, z$; (iii) $x-1 / 2, y,-z+1 / 2$; (iv) $x+1 / 2, y,-z+1 / 2$; (v) $-x+1 / 2, y+1 / 2, z$; (vi) $-x+3 / 2, y+1 / 2, z$.

Hydrogen-bond geometry $\left(A,{ }^{\circ}\right)$

\begin{tabular}{|c|c|c|c|c|}
\hline$D-\mathrm{H} \cdots A$ & $D-\mathrm{H}$ & $\mathrm{H} \cdots A$ & $D^{\cdots} A$ & $D-\mathrm{H} \cdots A$ \\
\hline $\mathrm{N} 3-\mathrm{H} 1 N \cdots \mathrm{O} 2^{\mathrm{vii}}$ & $0.88(1)$ & $2.27(2)$ & $3.144(6)$ & $172(6)$ \\
\hline $\mathrm{N} 3-\mathrm{H} 2 N \cdots \mathrm{O} 6^{\mathrm{viii}}$ & $0.88(1)$ & $2.28(5)$ & $2.984(6)$ & $138(6)$ \\
\hline $\mathrm{O} 1 W-\mathrm{H} 1 W \cdots \mathrm{O} 2^{\mathrm{i}}$ & $0.87(1)$ & $2.21(3)$ & $2.987(5)$ & $148(5)$ \\
\hline $\mathrm{O} 1 W-\mathrm{H} 2 W \cdots \mathrm{O} 6 W^{\text {ix }}$ & $0.87(1)$ & $1.92(2)$ & $2.766(6)$ & $161(6)$ \\
\hline $\mathrm{O} 2 W-\mathrm{H} 3 W^{\cdots} \cdot \mathrm{O}^{\mathrm{i}}$ & $0.88(1)$ & $2.03(3)$ & $2.772(6)$ & $141(5)$ \\
\hline $\mathrm{O} 2 W-\mathrm{H} 4 W \cdots \mathrm{N} 1^{\mathrm{ii}}$ & $0.88(1)$ & $2.10(2)$ & $2.948(6)$ & $162(5)$ \\
\hline $\mathrm{O} 3 W-\mathrm{H} 5 W \cdots \mathrm{O} 5 W^{\mathrm{x}}$ & $0.88(1)$ & $2.04(3)$ & $2.805(5)$ & $145(4)$ \\
\hline $\mathrm{O} 3 W-\mathrm{H} 6 W^{\cdots} \mathrm{O} 5 W^{\text {iv }}$ & $0.88(1)$ & $1.97(1)$ & $2.833(6)$ & $168(5)$ \\
\hline $\mathrm{O} 4 W-\mathrm{H} 7 W \cdots \mathrm{O} 4^{\text {ix }}$ & $0.88(1)$ & $2.06(2)$ & $2.901(5)$ & $160(4)$ \\
\hline $\mathrm{O} 4 W-\mathrm{H} 8 W^{\cdots} \cdots \mathrm{O} 6 W^{\mathrm{i}}$ & $0.88(1)$ & $1.87(2)$ & $2.741(5)$ & $171(5)$ \\
\hline $\mathrm{O} 5 W-\mathrm{H} 9 W \cdots \mathrm{O} 2$ & $0.88(1)$ & $1.97(3)$ & $2.805(5)$ & $158(6)$ \\
\hline $\mathrm{O} 5 W-\mathrm{H} 10 W \cdots \mathrm{O} 5^{\mathrm{i}}$ & $0.88(1)$ & $2.17(3)$ & $2.917(5)$ & $143(5)$ \\
\hline $\mathrm{O} 6 W-\mathrm{H} 11 W \cdots \mathrm{O} 3$ & $0.88(1)$ & $1.88(2)$ & $2.737(5)$ & $166(6)$ \\
\hline $\mathrm{O} 6 W-\mathrm{H} 12 W \cdots \mathrm{O} 3^{3 i i}$ & $0.88(1)$ & $1.93(1)$ & $2.800(6)$ & $174(5)$ \\
\hline
\end{tabular}

Symmetry codes: (i) $-x+1 / 2, y-1 / 2, z$; (ii) $-x+3 / 2, y-1 / 2, z$; (iii) $x-1 / 2, y,-z+1 / 2$; (iv) $x+1 / 2, y,-z+1 / 2$; (vii) $-x+1,-y+1,-z$; (viii) $x+1 / 2,-y+3 / 2,-z$; (ix) $-x+1, y-1 / 2,-z+1 / 2$; (x) $x+1, y, z$. 